\title{
Methane bioactivity and interactions with other biological gases
}

\author{
András T. Mészáros M.D. \\ University of Szeged, \\ Institute of Surgical Research, Szeged, Hungary
}

Ph.D. Thesis

University of Szeged, Faculty of Medicine,

Doctoral School of Multidisciplinary Medicine

Szeged, Hungary

\section{Supervisors:}

Mihály Boros M.D., Ph.D., D.Sc.

University of Szeged, Institute of Surgical Research

Szeged, Hungary

Andrey V. Kozlov M.D., Ph.D.

Ludwig Boltzmann Institute for Experimental and Clinical Traumatology

Vienna, Austria 



\section{List of full papers related to the subject of the thesis}

I. Mészáros AT, Büki T, Fazekas B, Tuboly E, Horváth K, Poles MZ, Szücs Sz, Varga G, Kaszaki $\mathrm{J}$, Boros M: Methane inhalation preserves the epithelial barrier during ischemia and reperfusion in the rat small intestine. Surgery, 2017. (accepted for publication)

IF: 3.309

II. Tuboly E*, Mészáros A*, Boros M: Nonbacterial biotic methanogenesis, possible mechanisms and significance. In: Methanogenesis: Biochemistry, Ecological Functions, Natural and Engineered Environments. Badalians G.G. (ed.). Nova Science Publishers, Inc. NY, USA 2014, Chapter 2, pp. 19-49. ISBN 978-1-63321-567-2.

*Equal contribution

III. Dumitrescu SD*, Meszaros AT*, Puchner S, Weidinger A, Boros M, Redl H, Kozlov AV: EPR analysis of extra- and intracellular nitric oxide in liver biopsies. Magnetic Resonance in Medicine, 2016. (Epub ahead of print)

* Equal contribution IF: 3.782

IV. Boros M, Tuboly E, Mészáros A, Amann A: The role of methane in mammalian physiology - is it a gasotransmitter? Journal of Breath Research, 2015; 9: 014001

IF: 4.177

V. Kaszaki J, Mészáros A, Büki T, Varga G, Érces D, Boros M: Pathophysiology of intestinal ischemia and reperfusion - novel therapeutic possibilities. Magyar Belorvosi Archívum, 2013; 66: 6-12.

VI. Kozlov AV, Bernardi P, Lancaster J, Meszaros AT, Weidinger A: Mitochondrial pathways linking acute inflammation and liver failure, a hypothesis about key role of mitochondrial ROS.

Submitted for publication

\section{List of abstracts related to the subject of the thesis}

I. Mészáros A, Büki T, Horváth K, Fazekas B, Varga G, Kaszaki J, Kupai K, Ghyczy M, Boros M: Exogenous methane reduces mesenteric barrier damage caused by ischemia-reperfusion injury. Archives of the Hungarian Medical Association of America Vol 18 (1): 20, 2010.

II. Mészáros A, Büki T, Varga G, Tökés T, Kaszaki J, Boros M: Effects of the methane treatment on the early morphological and functional consequences of the experimental mesenteric ischaemia and reperfusion. Archives of the Hungarian Medical Association of America Vol 20 (2): 49, 2012.

III. Mészáros AT, Büki T, Varga G, Tökés T, Kaszaki J, Boros M: Effects of Methane on the Functional and Morphological Consequences of Experimental Mesenteric Ischemia and Reperfusion. European Surgical Research 50 (S1): 1, 2013.

IV. Mészáros A, Fischer-Szatmári T, Szücs Sz, Varga G, Boros M: A vékonybél nyálkahártya változásai az ischaemia-reperfúzió folyamán - megbízható-e a szövettani eredmény? Magyar Sebészet 66 (2): 99, 2013.

V. Érces D, Nógrády M, Mészáros A, Varga G, Ghyczy M, Kaszaki J, Boros M: Methane Inhalation in the Early Phase of Resuscitation Reduces Intestinal Injury After Experimental Cardiac Tamponade. Shock 40, Suppl. 1: 23, 2013.

VI. Érces D, Nógrády M, Mészáros A, Varga G, Földesi I, Ghyczy M, Kaszaki J, Boros M: Decreased intestinal injury after resuscitation with methane inhalation during experimental cardiac tamponade. Cardiologica Hungarica 43, G12, 2013.

VII. Mészáros AT, Strifler G, Komlodi T, Nagy A, Cao C, Kaszaki J, Tretter L, Boros M: Mitochondrial (dys)function in small intestinal samples - how can we assess it? European Surgical Research 55 (suppl 1): 57, 2015.

VIII. Dumitrescu S, Mészáros A, Puchner S, Weidinger A, Kaszaki J, Boros M, Redl H, Kozlov A: Analysis of NO production in intact liver biopsies. Shock 44, Suppl. 2: 11-12, 2015. 


\section{List of abstracts published in conference proceedings related to the subject of the thesis:}

I. Mészáros A, Büki T, Varga G, Tőkés T, Kaszaki J, Boros M: Metán kezelés hatása a kísérletes mesenteriális ischaemia-reperfúzió korai morfológiai és funkcionális következményeire. Magyar Haemorheologiai Társaság (MHT) XIX., és a Magyar Mikrocirkulációs és Vaszkuláris Biológiai Társaság (MMVBT) III. Közös Kongresszusa, Balatonkenese, 2012. 04. 27-28.

II. Mészáros A, Büki T, Varga G, Tőkés T, Kaszaki J, Boros M: Metán belélegeztetés hatása a kísérletes mesenteriális ischaemia-reperfúzió korai morfológiai és funkcionális következményeire. A Magyar Élettani Társaság, Kongresszusa, Fiatal kutatók fóruma, Debrecen, 2012. 06. 10-13.

III. Mészáros A, Büki T, Varga G, Tökés T, Kaszaki J, Boros M: Effects of methane treatment on the early morphological and functional consequences of experimental mesenteric ischemia and reperfusion. 11. Cserháti István Emlékülés, Szeged, 2012. 11. 22-23.

IV. Mészáros A, Varga G, Tuboly E, Tóth A, Sándor B, Rábai M, Kenyeres P, Késmárky G, Kaszaki J, Tóth K, Boros M: In vitro metán kezelés hatása vörösvértestek deformabilitási és aggregációs paramétereire. 44. Membrán-Transzport Konferencia, Sümeg, 2014. május 20- 23.

V. Strifler G, Mészáros A, Chun C, Kaszaki J, Boros M: Metán kezelés hatása a mitokondriális múködésre anoxia-reoxigenizáció után. 44. Membrán-Transzport Konferencia, Sümeg, 2014. május 20- 23.

VI. Mészáros A, Strifler G, Komlódi T, Nagy A, Cao C, Kaszaki J, Tretter L, Boros M: Methodological aspects of assessing mitochondrial function in small intestinal mucosal samples of rats and guinea pigs. $10^{\text {th }}$ Mitocondrial Physiology Conference, Obergurgl, Ausztria, 2014. szeptember 8-12.

VII. Boros M, Tuboly E, Hartmann P, Strifler G, Mészáros A: Methane and mitochondria. A Magyar Élettani Társaság 79. Vándorgyülése, Szeged, 2015. május 27-30.

VIII. Mészaros AT, Büki T, Varga G, Kaszaki J, Boros M: Methane Treatment Improves Intestinal Morphology and Function in Experimental Mesenteric Ischemia and Reperfusion. $39^{\text {th }}$ Seminar of the Austrian Society for Surgical Research, Wagrain, Austria. 2015. november 19-21.

\section{List of full papers related to the field of the thesis:}

I. Tuboly E, Futakuchi M, Varga G, Érces D, Tőkés T, Mészáros A, Kaszaki J, Suzui M, Imai M, Okada A, Okada N, Boros M, Okada H. C5a inhibitor protects against ischemia/reperfusion injury in rat small intestine. Microbiology and Immunology, 2016; 60(1): 35-46. $\quad$ IF: 1.428

II. Strifler G, Tuboly E, Szél E, Kaszonyi E, Cao C, Kaszaki J, Mészáros A, Boros M, Hartmann P Inhaled methane limits the mitochondrial electron transport chain dysfunction during experimental liver ischemia - reperfusion injury. PLoS One, 2016;11(1):e0146363

IF: 3.057

III. Érces D, Nógrády M, Varga G, Szücs S, Mészáros AT, Fischer-Szatmári T, Cao C, Okada N, Okada H, Boros M, Kaszaki J. Complement C5a inhibition improves late hemodynamic and inflammatory changes in a rat model of non-occlusive mesenteric ischemia. Surgery, 2016;159(3):960-71

IF: 3.309 


\section{Contents}

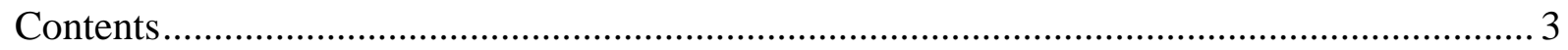

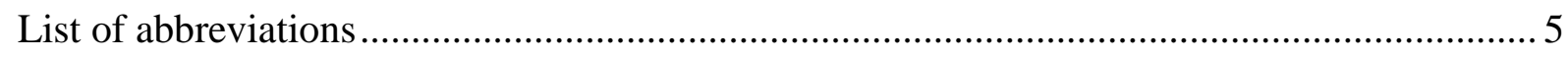

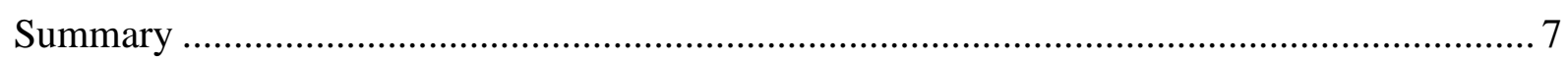

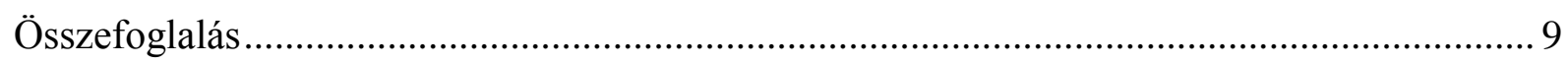

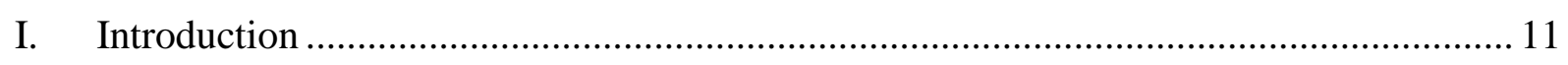

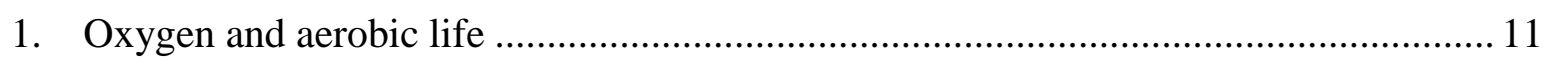

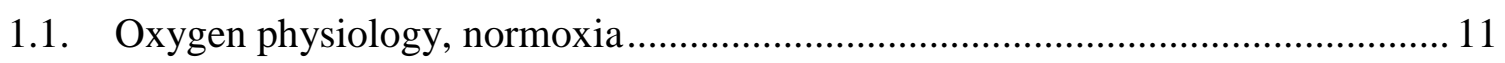

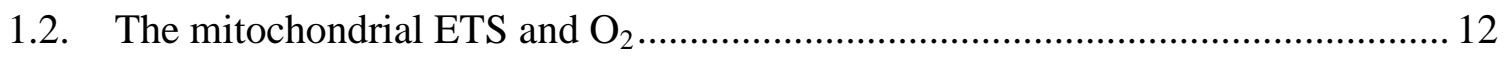

1.3. Sources and sinks of mitochondrial reactive oxygen species (ROS) .................... 12

2. Hypoxia and reoxygenation, ischemia and reperfusion, pathological ROS generation 13

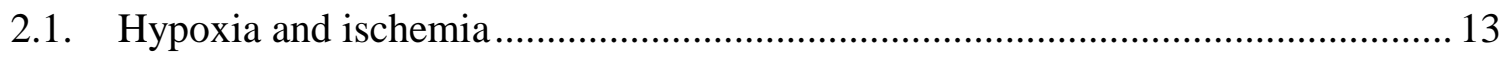

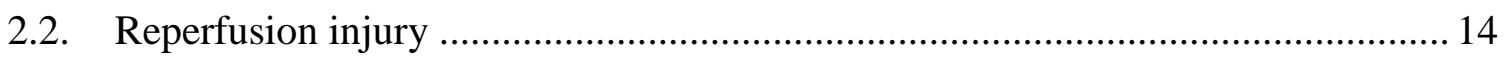

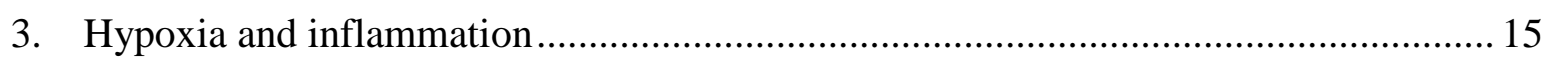

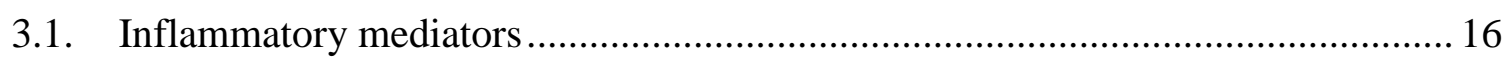

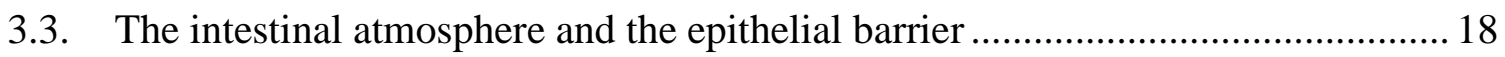

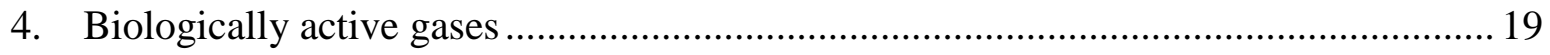

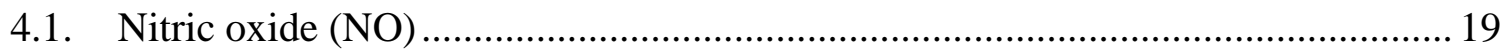

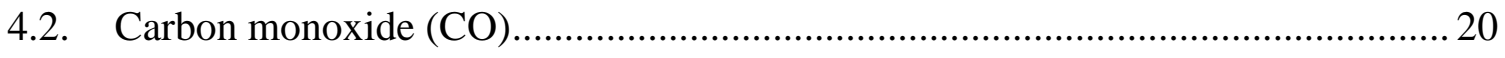

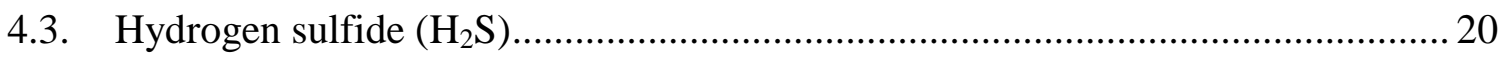

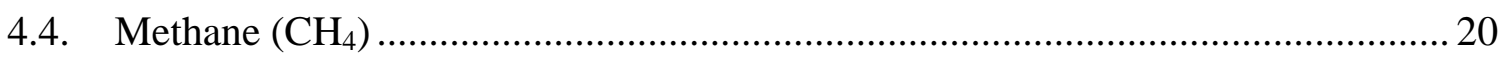

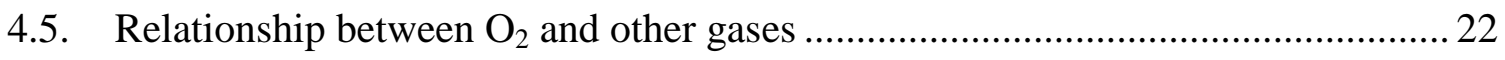

5. Mitochondrion: the hub of interactions of gaseous compounds .................................. 24

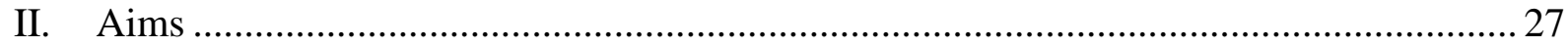

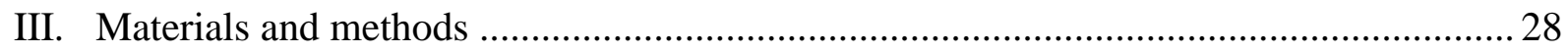

1. An in vivo study to investigate the effects of $\mathrm{CH}_{4}$ treatments in mesenteric IR .......... 28

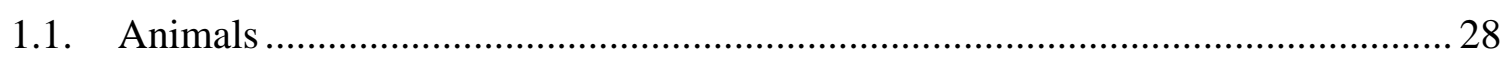

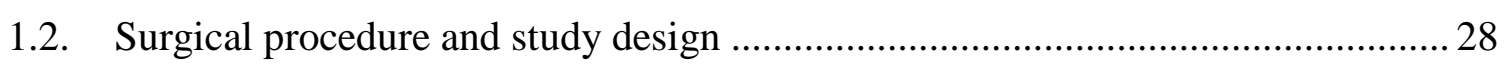

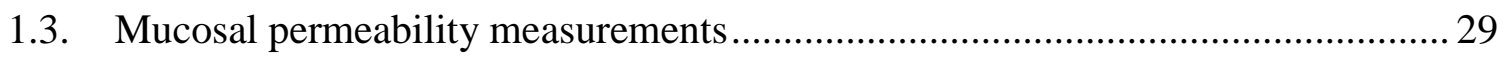

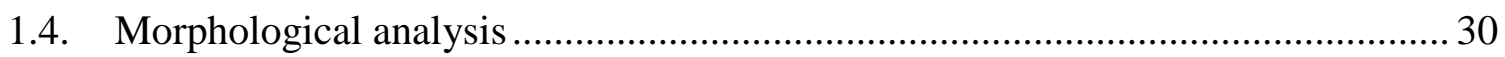

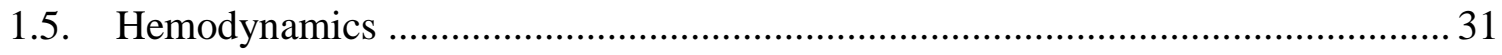

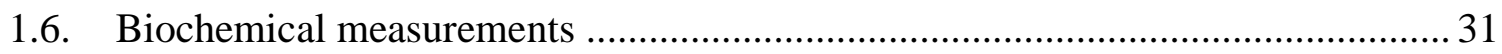

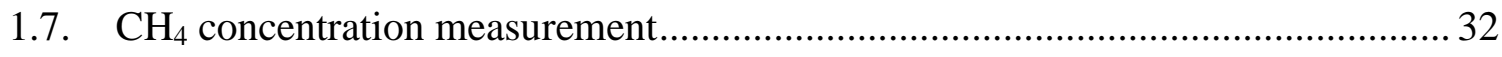

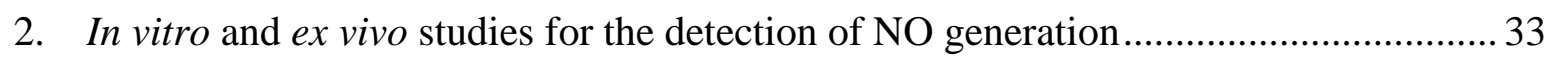

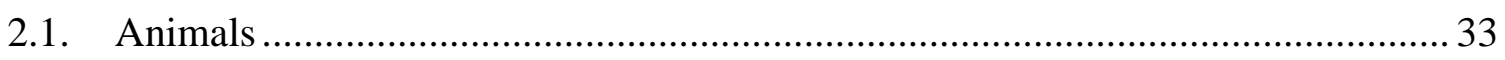

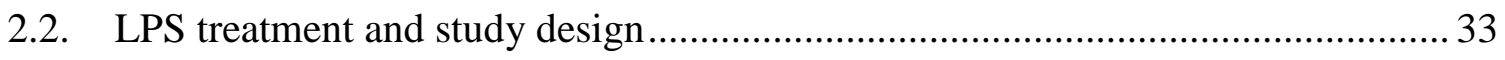

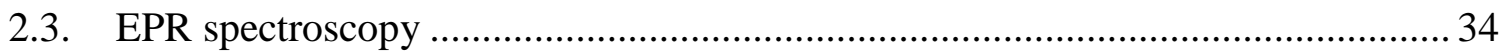




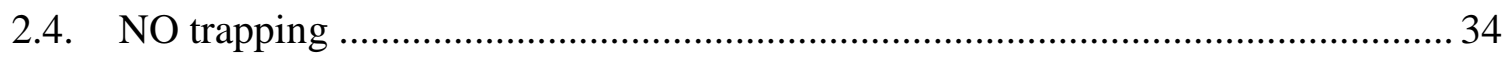

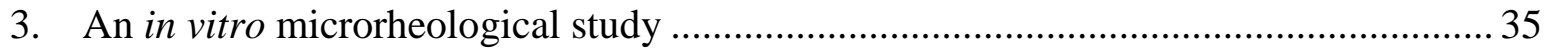

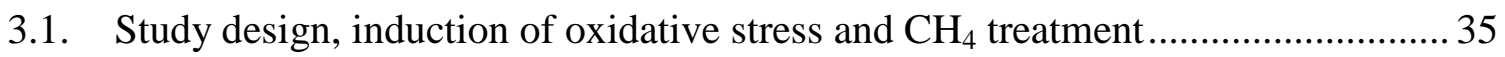

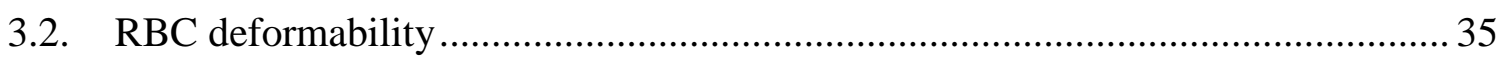

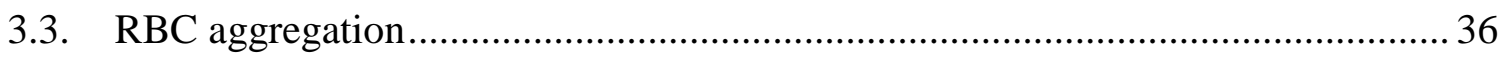

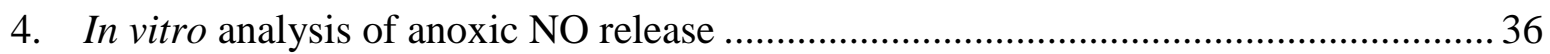

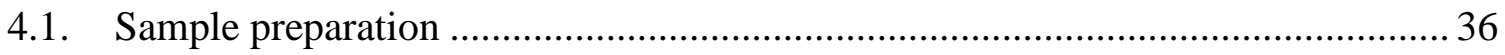

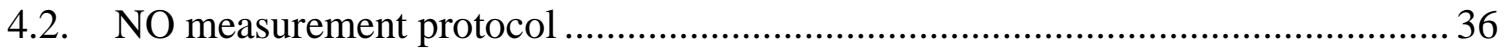

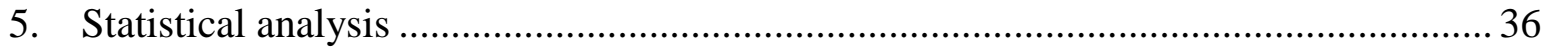

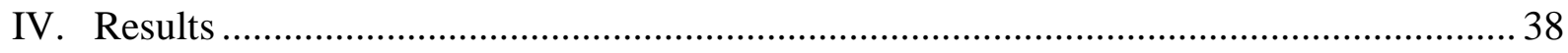

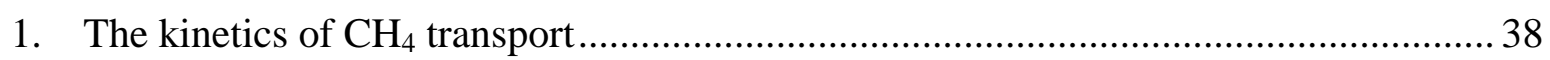

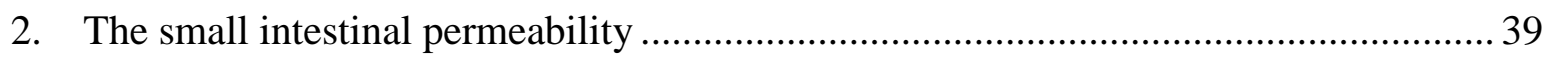

3. The detection of NO by EPR without exogenously added spin-trapping molecules .... 45

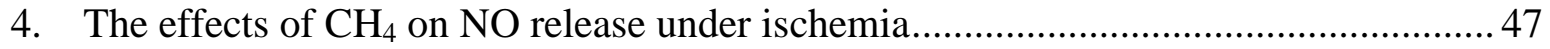

5. The effects of $\mathrm{CH}_{4}$ on the microhemorheological parameters of whole blood ............. 49

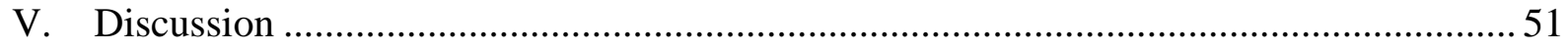

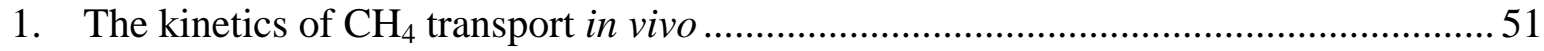

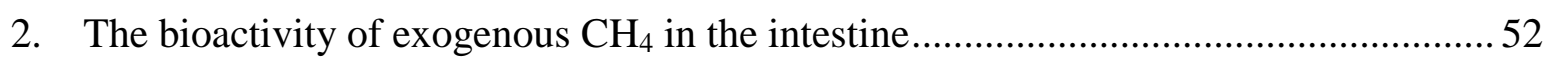

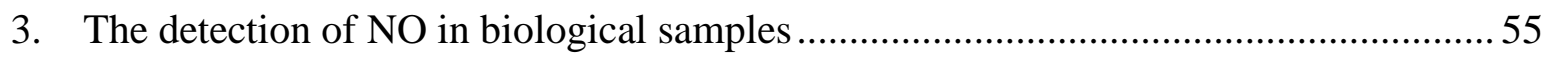

4. The interaction of $\mathrm{CH}_{4}$ with NO-related nitrosative stress ..........................................56

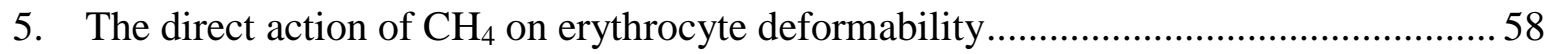

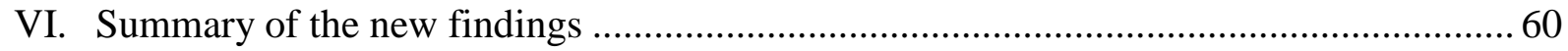

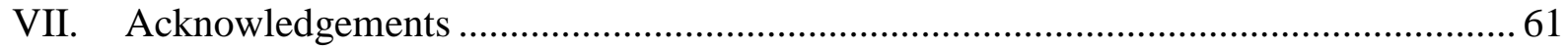

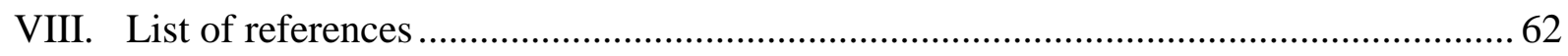

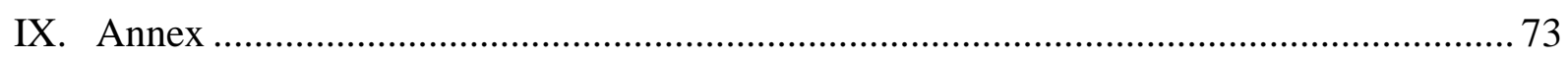




\section{List of abbreviations}

$\begin{array}{ll}\text { AJ } & \text { adherent junction } \\ \text { bw } & \text { body weight } \\ \text { CI, II, III, IV } & \text { mitochondrial electron transport chain complex I-IV } \\ \mathrm{CH}_{4} & \text { methane } \\ \text { CK } & \text { creatine kinase } \\ \text { CLSEM } & \text { confocal laser scanning endomicroscopy } \\ \text { CO } & \text { carbon monoxide } \\ \text { CO } & \text { carbon dioxide } \\ \Delta \psi_{\mathrm{m}} & \text { mitochondrial membrane potential } \\ \text { DETC-Fe } & \text { iron-diethylthiocarbamate } \\ \text { DMSO } & \text { dimethylsulfoxide } \\ \text { DNIC } & \text { dinitrosyl-iron complexes (see also NO-Fe) } \\ \text { e/i/nNOS } & \text { endothelial/inducible/neuronal nitric oxide synthase } \\ \text { Em } & \text { emission } \\ \text { EP } & \text { epithelial permeability } \\ \text { EPR } & \text { electron paramagnetic resonance } \\ \text { ET-1 } & \text { endothelin-1 } \\ \text { ETS } & \text { mitochondrial electron transport system } \\ \text { Ex } & \text { excitation }\end{array}$

FD4 $4 \mathrm{kDa}$ fluorescein isothiocyanate-dextran

$\mathrm{Fe} \quad$ iron

GI gastrointestinal

$\mathrm{H}_{2} \mathrm{~S} \quad$ hydrogen sulfide

$\mathrm{Hb}$ hemoglobin

IL interleukin

IMM inner mitochondrial membrane

ip intraperitoneal

IR ischemia-reperfusion

$\mathrm{K}_{\mathrm{M}} \quad$ Michaelis constant

LPS lipopolysaccharide

MPO myeloperoxidase

mPTP mitochondrial permeability transition pore 


\begin{tabular}{|c|c|}
\hline mtROS & mitochondrial reactive oxygen species \\
\hline MW & molecular weight \\
\hline $\mathrm{N}_{2}$ & nitrogen \\
\hline NO & nitric oxide \\
\hline $\mathrm{NO}_{2}^{-}$ & nitrite ion \\
\hline $\mathrm{NO}_{3}^{-}$ & nitrate ion \\
\hline $\mathrm{NO}-\mathrm{Fe}$ & dinitrosyl-iron complex \\
\hline $\mathrm{NO}-\mathrm{Hb}$ & mononitrosyl-hemoglobin complex \\
\hline $\mathrm{O}_{2}^{\bullet-}$ & superoxide radical \\
\hline OMM & outer mitochondrial membrane \\
\hline ONOO & peroxynitrite \\
\hline OXPHOS & oxidative phosphorylation \\
\hline PAS & photoacoustic spectroscopy \\
\hline PMN & polymorphonuclear leukocyte \\
\hline PMS & phenazine methosulfate \\
\hline $\mathrm{RBC}$ & red blood cell \\
\hline RNS & reactive nitrogen species \\
\hline ROS & reactive oxygen species \\
\hline RSNO & S-nitrosothiol \\
\hline sGC & soluble guanylate cyclase \\
\hline SMA & superior mesenteric artery \\
\hline $\mathrm{TJ}$ & tight junction \\
\hline TNF- $\alpha$ & tumor necrosis factor alpha \\
\hline TLR4 & Toll-like receptor 4 \\
\hline $\mathrm{VP}$ & vascular permeability \\
\hline $\mathrm{XDH}$ & xanthine dehydrogenase \\
\hline $\mathrm{XO}$ & xanthine oxidase \\
\hline XOR & xanthine oxidoreductase \\
\hline
\end{tabular}




\section{Summary}

Today it is recognized that a variety of enzymes are generating gas mediators, molecules that exert important physiological functions. Also, there is a growing body of evidence which suggests that methane $\left(\mathrm{CH}_{4}\right)$ can be produced in the eukaryotic cell. The antiinflammatory potential of exogenously supplemented $\mathrm{CH}_{4}$ has been repeatedly confirmed as well, but important details of the mechanism of action still need to be clarified. The main purpose of the thesis was to summarize and interpret previous data on the in vivo properties of exogenous $\mathrm{CH}_{4}$ in order to design and conduct further experiments, which help to extend our knowledge on the possible role and mechanisms of action of $\mathrm{CH}_{4}$ in mammalians.

Therefore, our first general aim was to explore the effects of normoxic $\mathrm{CH}_{4}$ administration in a small animal model of mesenteric ischemia-reperfusion (IR) induced inflammation. The early and later consequences of intestinal IR were characterized by mucosal permeability, biochemical, macro- and microcirculatory and morphological parameters. The IR-induced circulatory and structural damage was accompanied by increased epithelial permeability, demonstrating mucosal barrier damage. An assessment of the kinetics of the inhaled $\mathrm{CH}_{4}$ revealed that in our inhalation regime, at the end of ischemia significant amounts of $\mathrm{CH}_{4}$ are already in the systemic circulation, allowing rapid equilibration with the intestinal tissue early in the reperfusion, as confirmed by photoacoustic spectroscopy measurements. Normoxic $\mathrm{CH}_{4}$ inhalation effectively prevented the elevation of intestinal epithelial permeability, maintaining structural integrity of the mucosa and improving biochemical signs of inflammation in the early reperfusion. These data support previous findings on $\mathrm{CH}_{4}$ bioactivity and establish a mucosa-protective role for exogenous $\mathrm{CH}_{4}$ to modulate the IR-induced pro-inflammatory activity locally in the small intestine.

Our second general aim was to delineate the mechanisms of action of $\mathrm{CH}_{4}$ in models of tissue hypoxia with elevated levels of reactive oxygen and nitrogen species, with special emphasis on the possible relationship of $\mathrm{CH}_{4}$ with other biological gases, such as nitric oxide (NO).

Based on the above results two hypotheses for the mechanism of action were formulated and tested. First, we supposed that $\mathrm{CH}_{4}$ is able to directly influence cell membrane rigidity. Accordingly, we set out to investigate the influence of $\mathrm{CH}_{4}$ on changes in erythrocyte deformability provoked by oxidative stress in vitro. The results revealed that $\mathrm{CH}_{4}$ in vitro improves the deformability of red blood cells during simulated oxidative stress, which may 
contribute to the improvement of the effectiveness of mesenteric microcirculation in the postischemic small intestine.

The second hypothesis of action of exogenous $\mathrm{CH}_{4}$ was a direct interaction with NO metabolism. A new, non-toxic, exogenous spin trap-free electron paramagnetic resonance (EPR) spectroscopy method was developed for NO detection. The method was validated in a bacterial endotoxin-based in vivo experimental model of inflammation where NO concentration was measured from both the intra- and extracellular compartments of the same samples in tissue biopsies. With EPR spectroscopy reduced NO levels were detected in the ischemic intestinal tissue after normoxic $\mathrm{CH}_{4}$ administration. Considering this information, we set out to measure NO release in real-time in vitro from liver tissue homogenate under anoxic conditions, mimicking ischemic tissue. $\mathrm{CH}_{4}$ treatment under such conditions inhibited NO release. Collectively, these results confirm that exogenous $\mathrm{CH}_{4}$ administration effectively reduces NO levels in the ischemic tissue.

In conclusion, our data demonstrates an anti-inflammatory and mucosa-protecting role of $\mathrm{CH}_{4}$ in intestinal IR. To shed light on the mechanism of action, we confirmed direct effects of $\mathrm{CH}_{4}$ on oxidized erythrocyte membranes and that increased $\mathrm{CH}_{4}$ input reduces $\mathrm{NO}$ production and nitrotyrosine levels in hypoxic and anoxic organs. 


\section{Összefoglalás}

Napjainkra számos enzimről bizonyosodott be, hogy gáznemü jelátvivő molekulák termelésére képesek. Ezen mediátorok fontos élettani funkciókat szabályoznak. Egyre több bizonyíték szól amellett, hogy eukarióta sejtekben metán $\left(\mathrm{CH}_{4}\right)$ képződhet. A kívülről bejuttatott $\mathrm{CH}_{4}$ gyulladásgátló hatását is többször megerősítették, azonban a hatásmechanizmus fontos részletei még tisztázatlanok. E dolgozat fó célja az exogén $\mathrm{CH}_{4}$ in vivo hatásairól rendelkezésre álló adatok összegzése és értelmezése, majd további kísérletek tervezése és kivitelezése volt, melyek gyarapíthatják tudásunkat a $\mathrm{CH}_{4}$ emlösökben betöltött szerepéről.

Első fő célunk a normoxiás $\mathrm{CH}_{4}$ bevitel hatásainak és következményeinek vizsgálata volt mesenteriális ischaemia-reperfúzió (IR) által okozott gyulladásos reakció alatt. A vékonybél IR korai és késői következményeit a nyálkahártya permeabilitás meghatározásával, biokémiai, makro- és mikrohaemodinamikai valamint morfológiai vizsgálatokkal jellemeztük. A vékonybél IR mikrokeringési és strukturális károsodása megemelkedett epitheliális permeabilitással járt, jelezve a mucosa barrier károsodását. A belélegzett $\mathrm{CH}_{4}$ időbeli szöveti eloszlásának fotoakusztikus spektroszkópos vizsgálata feltárta, hogy az általunk alkalmazott lélegeztetési módszerrel már az ischaemia végén jelentős mennyiségű $\mathrm{CH}_{4}$ van a szisztémás keringésben, mely a bélben a koncentráció gyors kiegyenlítődését teszi lehetővé a reperfúzió elején. Normoxiás $\mathrm{CH}_{4}$ belélegzése hatékonyan gátolta a vékonybél epitheliális permeabilitás növekedését, megörizte a mucosa strukturális épségét és mérsékelte a gyulladás biokémiai jeleit a korai reperfúzió során. Az adatok megerősítik a $\mathrm{CH}_{4}$ bioaktivitását bizonyító adatokat és megalapozzák az exogén $\mathrm{CH}_{4}$ gyulladáscsökkentő, nyálkahártya-védő hatását IR alatt.

Másik fö célunk a $\mathrm{CH}_{4}$ hatásmechanizmusának további feltárása volt szöveti hypoxiával, valamint fokozott reaktív oxigén és nitrogén származék képződéssel jellemzett modellekben. Ennek során a $\mathrm{CH}_{4}$ egyéb gázokkal, pl. nitrogén-monoxiddal (NO) való kölcsönhatásaira fektettünk külön hangsúlyt.

A fenti eredmények alapján két elméletet dolgoztuk ki és vizsgáltuk meg. Elsőként azt feltételeztük, hogy a $\mathrm{CH}_{4}$ közvetlenül képes a sejtmembrán-rigiditás befolyásolására. Ehhez megvizsgáltuk a $\mathrm{CH}_{4}$ in vitro hatását az oxidatív stressz által kiváltott vörösvérsejt deformabilitás változásokra. Eredményeink szerint in vitro szimulált oxidatív stressz alatt a $\mathrm{CH}_{4}$ javítja a vörösvérsejtek deformabilitását, mely ezáltal hozzájárulhat a mesenteriális mikrokeringés hatékonyságának javulásához ischaemiát követően. 
A második elmélet szerint az exogén $\mathrm{CH}_{4}$ közvetlenül képes befolyásolni a $\mathrm{NO}$ metabolizmust. Egy új, nem toxikus, exogén spincsapda-mentes, elektron paramágneses rezonancia (EPR) spektroszkópos módszert dolgoztunk ki a NO mérésére. A módszert validáltuk egy bakteriális endotoxin-alapú gyulladás állatmodelljében ugyanazon szövetbiopsziából történő intra- és extracelluláris NO meghatározásra is. EPR spektroszkópiával csökkent NO szintet mutattunk ki vékonybél szövetben in vivo normoxiás $\mathrm{CH}_{4}$ kezelés után. Ezen eredményeket megfontolva további vizsgálatokat végeztünk a $\mathrm{NO}$ felszabadulás valós idejü mérésére máj szövet homogenizátumból, anoxiás körülmények

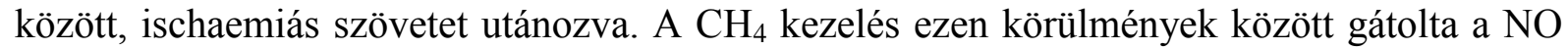
felszabadulást. Összességében ezen eredmények igazolják, hogy exogén $\mathrm{CH}_{4}$ alkalmazása csökkenti az ischaemiás szövet NO szintjét.

Összefoglalva, adataink a $\mathrm{CH}_{4}$ gyulladásgátló és nyálkahártya védő hatását bizonyítják vékonybél IR során. Hogy fényt derítsünk a hatásmechanizmusra, kimutattuk, hogy a $\mathrm{CH}_{4}$ közvetlenül befolyásolja az oxidált vörösvérsejt membránt és hogy megnövekedett $\mathrm{CH}_{4}$ bevitel csökkenti az anoxiás és hypoxiás szövetek NO termelését és a nitrotirozin szintet. 


\section{Introduction}

\section{Oxygen and aerobic life}

In most vertebrate tissues the majority of oxygen $\left(\mathrm{O}_{2}\right)$ is consumed by mitochondria, the powerhouses of cells. During the aerobic metabolism ATP is produced by protein complexes of the electron transport system (ETS) embedded in the inner mitochondrial membrane (IMM). In the last cascade step of the electron transfer fed by the metabolites of the citrate cycle, the final electron acceptor $\mathrm{O}_{2}$ is reduced at the cytochrome c oxidase (EC 1.3.3.1) producing $\mathrm{H}_{2} \mathrm{O}$ :

$$
4 \mathrm{cyt} \mathrm{c}^{2+}+8 \mathrm{H}_{\mathrm{M}}^{+}+\mathrm{O}_{2} \rightarrow 4 \mathrm{cyt} \mathrm{c}^{3+}+4 \mathrm{H}_{\mathrm{I}}^{+}+2 \mathrm{H}_{2} \mathrm{O}
$$

(cyt c: cytochrome c, $\mathrm{H}^{+}$: matrix $\mathrm{H}^{+}, \mathrm{H}^{+}$: intermembrane $\mathrm{H}^{+}$.)

This process contributes to more than $90 \%$ of the total $\mathrm{O}_{2}$ consumption of the human body. In addition, over 60 enzymes are consumers of the cellular $\mathrm{O}_{2}$, including oxidases (e.g. xanthine oxidase (EC 1.17.3.2), aldehyde oxidase (EC 1.2.3.1), amine oxidases, NADPH oxidases), and mono- and dioxygenases (e.g. lipoxygenases of the arachidonic acid cascade, cytochrome p450 monooxygenase, etc.) (Vanderkooi et al., 1991). Interestingly, in contrast to most cell types, not mitochondria, but phagocytic NADPH oxidase is the major sink of $\mathrm{O}_{2}$ in activated polymorhonuclear (PMN) leukocytes during the "respiratory burst" since these cells generally rely on glycolysis (Segal et al., 1978).

\subsection{Oxygen physiology, normoxia}

Normoxia generally refers to $20-21 \% \mathrm{O}_{2}$ in the atmosphere. Within the human body the $\mathrm{O}_{2}$ gradient gradually decreases in the respiratory system and across the cells, reaching its lowest value in the vicinity of mitochondria. The partial pressure of $\mathrm{O}_{2}\left(\mathrm{pO}_{2}\right)$ in the lung alveoli is $100-110 \mathrm{mmHg}$ (approx. $13 \mathrm{kPa}), 90-110 \mathrm{mmHg}(12.0-14.7 \mathrm{kPa}$ ) in the arterial blood, well above the normal extracellular $\mathrm{pO}_{2}$ levels in solid organs $(40 \mathrm{mmHg}$ in the neocortex and $10 \mathrm{mmHg}$ in the luminal parts of the colon) (Erecinska et al., 2001; Gnaiger, 2003). Nevertheless, the partitioning factor of $\mathrm{O}_{2}$ is roughly 3 , thus local concentrations of $\mathrm{O}_{2}$ in cellular and mitochondrial membrane fractions are enhanced (Subczynski et al., 1983).

Here, it should be mentioned that the $\mathrm{O}_{2}$ level in cell cultures is usually much higher than in vivo, because in the majority of studies they are incubated at air oxygen pressure. In this case the $\mathrm{O}_{2}$ concentration is reaches approximately $200 \mu \mathrm{M}(160 \mathrm{mmHg})$ in the incubation medium at $37^{\circ} \mathrm{C}$ and ambient pressure, representing relative hyperoxia compared to the in vivo situations (Gnaiger, 2003; van Faassen et al., 2009). 


\subsection{The mitochondrial ETS and $\mathrm{O}_{2}$}

Mitochondria are spatially separated intracellular sites hosting a series of oxidoreductive reactions coupled to proton pumping. The initial shuttle carrier of electrons from the citric acid cycle to the membrane-bound respiratory chain of flavoproteins is the $\mathrm{NAD}^{+} / \mathrm{NADH}$ couple. Complex I (CI, NADH:ubiquinone oxidoreductase, EC 1.6.5.3) feeds electrons in the ubiquinone pool located in the IMM. Subsequently, electrons are carried by Complex III (CIII, cytochrome c reductase, EC 1.10.2.2) to cytochrome $\mathrm{c}$ and then to Complex IV (CIV, cytochrome c oxidase, EC 1.9.3.1), where $\mathrm{O}_{2}$, the final electron acceptor, is reduced. The other main way of electrons converging at the ubiquinone pool is driven by Complex II (CII, succinate dehydrogenase, EC 1.3.5.1), the only membrane-bound enzyme of the citrate cycle. According to the chemiosmotic coupling hypothesis of Mitchell (1961), protons are pumped with the energy of oxidation-reduction at the CI, CIII and CIV across the IMM to the intermembrane space, which is the driving force of the ATP synthesis by the $\mathrm{F}_{0^{-}}$ $\mathrm{F}_{1}$ ATPase (Mitchell, 2011).

\subsection{Sources and sinks of mitochondrial reactive oxygen species (ROS)}

According to Vladimir Skulachev "living with the risk of oxidative stress is a price that aerobic organisms must pay for more efficient bioenergetics" (Skulachev, 1996). During the electron transfer over the ETS 1-4\% of electrons "leak", producing partially reduced superoxide $\left(\mathrm{O}_{2}{ }^{\bullet-}\right)$, the primary reactive oxygen species (ROS) in the eukaryotic cell (Chance et al., 1961). There are at least 10 known enzymes in mammalian mitochondria which are able to produce ROS, some of them at several sites within the same protein complexes (i.e. CI, CII and CIII), these also include the cytochrome b5 reductase, monoamine oxidases A and $\mathrm{B}$, dihydroorotate dehydrogenase, glycerol-3-phosphate dehydrogenase, aconitase, and the $\alpha$ ketoglutarate dehydrogenase complex (Andreyev et al., 2005; Quinlan et al., 2012). However, most of the experiments that indicate net ROS production of these organelles were done on isolated mitochondria or on submitochondrial particles, usually by means of detection methods, which are based on trapping reactive species by molecules that have a high affinity to ROS, generating detectable adducts upon reaction. Optical and electron spin resonance spectroscopic techniques are commonly used to detect such adducts.

The rate of ROS production strongly depends on the metabolic state of the cells and the contribution of mitochondria to the cellular ROS pool is still debated (Hansford et al., 1997; Tahara et al., 2009). It has been suggested that in situ, under physiological conditions, mitochondria might be more like sinks than sources of ROS, if the high antioxidative capacity of mitochondria is taken into account (Brown et al., 2012). The mitochondrial ROS- 
detoxifying mechanisms among others include the membrane lipid peroxide removal systems, phospholipid hydroperoxide glutathione peroxidase, manganese superoxide dismutase, cytochrome c, catalase, glutathione, glutathione-S-transferase, glutathione reductase, glutathione peroxidase and peroxiredoxins. This suggests that ROS production is tightly regulated and secured by several lines of antioxidant defense systems in intra- and extramitochondrial sites. Today it is commonly accepted that physiological levels of ROS regulate a variety of signaling pathways (e.g. NF- $\kappa \mathrm{B}, \mathrm{Nrf}-2$, STAT3) directly and indirectly (Hamanaka et al., 2010; Niture et al., 2014; Weidinger et al., 2015).

\section{Hypoxia and reoxygenation, ischemia and reperfusion, pathological ROS generation}

\subsection{Hypoxia and ischemia}

The impairment of arterial blood flow leads to tissue hypoxia, with lower-thanphysiological levels of $\mathrm{O}_{2}$; the exact value will depend on the energetic needs of the tissue which is already rate-limiting for mitochondrial oxidative phosphorylation (OXPHOS). Taking into account the fact that the $\mathrm{K}_{\mathrm{M}}$ value of cytochrome c oxidase is well below $1 \mu \mathrm{M}$ for $\mathrm{O}_{2}$ in uncoupled mitochondria, local hypoxia usually means $\mathrm{O}_{2}$ levels below $2 \mu \mathrm{M}$. However, the $\mathrm{K}_{\mathrm{M}}$ value is between 1-10 $\mu \mathrm{M}$ in states with a high proton motive force and a small difference in redox potential across the ETS (Petersen et al., 1974; Krab et al., 2011). Furthermore, $\mathrm{K}_{M}$ values for $\mathrm{O}_{2}$ of the most important $\mathrm{O}_{2}$-utilizing enzymes strongly depend on the presence of other substrates and gaseous compounds, such as nitric oxide (NO) and carbon monoxide (CO) (Thomas et al., 2001; Cooper et al., 2008).

The dysfunction of mitochondria is central to hypoxic tissue injuries. Several aspects of this condition have already been explored, such as impaired ATP production, an increase in ATP hydrolysis to maintain the mitochondrial membrane potential $\left(\Delta \psi_{\mathrm{m}}\right)$, dysregulated mitochondrial $\mathrm{Ca}^{2+}$ homeostasis and elevated ROS production (Di Lisa et al., 2006). Mitochondrial permeability transition is a process leading to the assembly and opening of a voltage-dependent, high conductance channel in the IMM. In pathological conditions, the sustained opening of mPTP can lead to irreversible mitochondrial damage and apoptosis. ROS and $\mathrm{Ca}^{2+}$ are known triggers of pore opening. Upon permeability transition, $\Delta \psi_{\mathrm{m}}$ collapses and ATP synthesis ceases. In a self-protecting endeavor of mitochondria to maintain $\Delta \psi_{\mathrm{m}}$, the cytosolic ATP from glycolysis is hydrolyzed by reversed ATP synthase, further depleting the energy sources of the cell. As a secondary process, the outer mitochondrial membrane (OMM) disrupts and cytochrome $\mathrm{c}$ will be released in the cytoplasm, inducing apoptosis (Bernardi et al., 2015). 


\subsection{Reperfusion injury}

The mitochondrial and non-mitochondrial pathophysiology of ischemia-reperfusion (IR) injury is a rather well-explored topic in biomedical research (Granger et al., 2015). In the absence of $\mathrm{O}_{2}$, which is the final electron acceptor of the respiratory chain, the cascade of redox reactions stops and reducing equivalents accumulate. Generally speaking, the duration of ischemia determines the survival of the affected tissue and the timely restoration of nutritive blood flow is essential to recover organ function. Reperfusion, however, paradoxically worsens the initial damage done by the ischemia itself. This is mainly due to the reintroduction of molecular $\mathrm{O}_{2}$ to previously ischemic tissue (originally proposed by Hearse (Hearse et al., 1973)). The decisive role of ROS formation, or more precisely, an imbalance between ROS production and detoxification was later demonstrated by Neil Granger (Granger et al., 1981). During hypoxia elevated mitochondrial ROS (mtROS) production occurs, mainly due to partial inhibition of respiratory chain enzymes (Kozlov et al., 1999), but this is much less than ROS produced upon reperfusion (Parks et al., 1986a).

An important contributing factor to elevated mtROS production upon reperfusion is succinate accumulation during ischemia (Chouchani et al., 2014). Previously, mtROS production had been considered a nonspecific process after the re-establishment of $\mathrm{O}_{2}$. The research team led by Murphy has shown that succinate is rapidly metabolized during the first minutes of reperfusion with concomitant increases of mtROS production by reverse electron transport at CI (Zweier et al., 1987; Murphy et al., 2008). In fact, the application of rotenone, an inhibitor of CI ameliorates the IR-induced mucosal damage in rodents (Ichikawa et al., 2004).

In addition to elevated mtROS production, pathological ROS production in the reperfusion period is fueled by cytosolic or extracellular sources. The most important ROS source in the postischemic tissue is probably xanthine oxidoreductase (XOR) (Harrison, 2002; Khambata et al., 2015). XOR is a complex molybdo-flavoenzyme, originally described by Schardinger in 1902 (Schardinger, 1902; Harrison, 2002). It exists as a homodimer of a single monomer with $150 \mathrm{kDa}$ MW (Andrews et al., 1964). Each monomer has a FAD domain, two iron-sulfur domains and a molybdopterin (Mo) binding site (Khambata et al., 2015). The latter is the site of purine catabolism and $\mathrm{NO}_{2}{ }^{-}$reduction, which is an important feature of the enzyme.

XOR is ubiquitous in mammals, being generally recognized as the terminal enzyme of purine catabolism, oxidizing hypoxanthine to xanthine and xanthine to uric acid (Harrison, 2002). XOR has two states, which are interconvertible. Xanthine dehydrogenase (XDH) is the 
predominant form under physiologic conditions and normoxia. XDH can be converted to xanthine oxidase $(\mathrm{XO})$ by reversible sulfhydryl oxidation or by limited proteolysis. The latter process is irreversible and occurs during tissue hypoxia at high levels of intracellular $\mathrm{Ca}^{2+}$ (Granger et al., 1986a). Both forms metabolize hypoxanthine, but $\mathrm{XO}$ produces $\mathrm{O}_{2}{ }^{\bullet-}$, which in turn forms $\mathrm{H}_{2} \mathrm{O}_{2}$. During ischemia hypoxanthine accumulates, hence $\mathrm{XO}$ contributes substantially to $\mathrm{O}_{2}{ }^{\bullet-}$ induced tissue injury during reperfusion. In 1986, Granger proposed that XOR is the major source of $\mathrm{O}_{2}^{\bullet-}$ during IR (Granger et al., 1986b) and although concerns have been raised over the time (Moorhouse et al., 1987), this model of postischemic $\mathrm{O}_{2}{ }^{\bullet-}$ generation is still widely accepted. Moreover, as has been recently shown, extracellular superoxide produced by XOR bound to GAGs on the endothelial surface of capillaries is a potent activator of PMNs through Toll-like receptor-4 (TLR4) (Lorne et al., 2008).

The highest levels of XOR in rodents and humans have been found in the liver and in the intestine (Parks et al., 1986b). Interestingly, Harrison and colleagues (Harrison, 2002) reported strongly positive anti-XOR antibody staining on the surface of human intestinal epithelial cells, and the enzyme was detected in the TJs of cultured intestinal epithelial cells as well.

\section{Hypoxia and inflammation}

Hypoxic conditions are inducing inflammation, and inflammatory disease states are frequently accompanied by tissue hypoxia. IR injury is also characterized by an inflammatory response and an important contributing factor to the oxidative tissue damage is the activation of the innate immune system. Extravasated leukocytes produce large quantities of $\mathrm{O}_{2}{ }^{\bullet-}$ by phagocytic NADPH oxidase and this mechanism can damage host cells and it also reduces tissue oxygenation by consuming $\mathrm{O}_{2}$ (Hernandez et al., 1987; Yang et al., 2009).

Activated PMNs are not only important contributors to the oxidative stress, but also play a significant role in microcirculatory derangements. The massive expression of adhesion receptors induces leukocyte rolling and firm adherence to postcapillary endothelial cells, which leads to elevated flow resistance, endothelial dysfunction and tissue edema (Menger et al., 1997; Szabo et al., 2008).

An important feature of reperfusion injury is the no-reflow phenomenon. The maintenance of normal red blood cell deformability is a prerequisite of intact microcirculation, since only bullet-shaped erythrocytes can pass capillaries freely. The peroxidation of membrane lipids of RBCs by oxidant species, such as peroxynitrite (ONOO), decreases the fluidity of the affected cellular membranes, contributing to reduced capillary 
blood flow (Dobretsov et al., 1977) and in severe cases, capillary stasis can develop (Vollmar et al., 2011). Notably, the direct effects of NO on membrane rigidity were shown earlier (Tsuda et al., 2000) and the adsorption of non-polar molecules in lipid bilayers was demonstrated in model experiments (Gruen et al., 1980).

\subsection{Inflammatory mediators}

The umbrella term "inflammatory mediator" covers molecules and cells contributing to the initiation, propagation and controlled cessation of the inflammation cascade. Most of them are "soluble" compounds such as cytokines, small protein products of immune cells or other cell types. The most prominent players in acute inflammation are tumor necrosis factor $\alpha$ (TNF- $\alpha$ ), interleukins (ILs), lipid mediators (e.g. leukotrienes), and the members of the complement cascade. However, the role of damage-associated molecular patterns (circulating mitochondrial DNA, HMGB-1, hyaluronan fragments, etc.) is increasingly recognized in sterile inflammation (Piccinini et al., 2010; Goodall et al., 2014; Maeda et al., 2014).

ROS (predominantly $\mathrm{H}_{2} \mathrm{O}_{2}$ ) are also local inflammatory signal transducer molecules. Gaseous compounds, such as $\mathrm{NO}, \mathrm{CO}$ and $\mathrm{H}_{2} \mathrm{~S}$ represent a special class of inflammatory mediators (Liu et al., 2012). From this perspective, the contribution of the inflammatory cells of the monocyte-macrophage axis is of especial importance in gas signal generation and the bulk release of cytokines as well (MacMicking et al., 1997).

\section{Endothelin-1 (ET-1) and interactions with NO}

The regulation of the microcirculation is accomplished by a continuous interaction of vasoconstrictor and vasodilator forces. NO and ET-1 are natural counterparts in this complex mechanism. ET-1, a pro-inflammatory compound, is the most potent vasoconstrictor agent that predominantly acts on $\mathrm{ET}_{\mathrm{A}}$ receptors, a subtype expressed mainly by vascular smooth muscle cells mediating vasoconstrictor effects. ET $_{\mathrm{B}}$ receptors on endothelial cells mediate mixed effects (Masaki, 2004; Schneider et al., 2007). It has been shown that even low concentrations of NO can effectively inhibit ET-1 release and ET-1-linked functions (Bourque et al., 2011). Shear stress induces NO production by eNOS, and NO, in turn, inhibits ET-1 release from cells (Kuchan et al., 1993). Multiple pathways of inhibition have been shown, but the most relevant under acute conditions is the inhibition of ET $_{\mathrm{A}}$-phospholipase $\mathrm{C}$ mediated intracellular $\mathrm{Ca}^{2+}$-release by NO (Goligorsky et al., 1994; Bourque et al., 2011). Reduced NO production during IR can leave ET-1-mediated vasoconstriction unopposed, leading to increased vascular tone and reduced microvasular blood flow, eventually exacerbating the IR injury (Martinez-Revelles et al., 2012). Importantly, increased levels of plasma ET-1 after intestinal IR were previously reported (Kurtel et al., 1999; Guzman-de la 
Garza et al., 2009) and ET-1 receptor blockers can alleviate mesenteric IR injury (Oktar et al., 2002).

\subsection{Intestinal IR injury}

The mucosa forms a physical defense barrier between the intestinal lumen and the body, thus any factor which jeopardizes this defense is of vital concern. Occlusive or nonocclusive mesenteric ischemia with subsequent reperfusion has a common consequence, which results in oxidative injury to the mucosa. The causes are energy imbalance, the activation of inflammatory pathways and uncontrolled interactions between ROS and reactive nitrogen species (RNS) resulting in damage to membrane lipids, proteins and DNA. This can cause an irreversible structural damage to biological membranes impairing their permeability and facilitating the leakage of toxins and bacteria from the intestinal lumen to the blood.

Being a component of the cell wall of Gram-negative bacteria, which are known to occur in abundance in the intestine, bacterial lipopolysaccharide (LPS, endotoxin) is thought to play an important role in the development of systemic inflammation, sepsis and multiple organ dysfunction syndrome originating from the gut after low flow states and IR conditions (Olofsson et al., 1985). The increased mucosal permeability of the intestine permits the translocation of LPS and even bacteria, initiating a TLR4-NF- $\kappa B$ mediated acute inflammation. The translocation of LPS leads to the priming of PMNs (Deitch et al., 1994; Moore et al., 1994) as well and the production of inflammatory cytokines, which, in turn, exacerbate systemic inflammation.

However, circulating LPS is only the tip of the iceberg, while the majority of LPS is attached to thrombocytes, erythrocytes and TLR4 on immune cells and parenchymal cells inducing variety of pathologic signaling cascades in those cells (Cavaillon et al., 2006).

The inflammatory response provoked by bacterial endotoxin in model systems is dose dependent. The LPS-linked reactions are mediated by TLRs and as part of the cellular stress response, the generation of both $\mathrm{O}_{2}{ }^{\bullet-}$ and NO is one of the major consequences of LPS exposure in various TLR4-expressing cell types, including macrophages, PMNs and endothelial cells (Mittal et al., 2014; Vaure et al., 2014). This, in turn, makes LPS a useful in vivo and in vitro tool for studying the activation of mammalian immune system and the production of inflammatory mediators. Since the majority of mechanistic studies on basic inflammatory reactions have been conducted in LPS models, a huge body of literature has accumulated and the exploration of novel reactions and pathways is easier under such well standardized circumstances. 


\subsection{The intestinal atmosphere and the epithelial barrier}

The gastrointestinal (GI) mucosal barrier is one of the most important frontiers of the body with an average area of $32 \mathrm{~m}^{2}$ in adults (Helander et al., 2014), a large interface between the milieu interieur and the surrounding luminal compounds. Although the composition of the Earth's atmosphere is relatively well known, but only incomplete datasets are available on the gas composition of the mammalian GI tract. In 1971, the survey of Levitt and colleagues reported on the gas composition of healthy human volunteers (Levitt, 1971), very low $\mathrm{O}_{2}$ levels $\left(\mathrm{O}_{2}: 0.69 \pm 0.49 \%\right)$ were found, and the average for $\mathrm{N}_{2}$ was $64 \pm 21 \%$, for $\mathrm{CO}_{2}: 14 \pm 7 \%$, for $\mathrm{H}_{2}: 19 \pm 16 \%$ and for $\mathrm{CH}_{4}$ levels ranging up to $20 \%$ in the producers. Much more data should be collected on this important subject, if we consider the dependency of biochemical processes on substrate concentrations. Nevertheless, it is well known that the small intestines and the colon have unique oxygenation profiles (Glover et al., 2016) and a number of mechanisms have been developed by intestinal cells to cope with this biochemical environment. The gut mucosa is metabolically very active, but $\mathrm{O}_{2}$ levels are rather low in the lumen of the bowel, reaching practically zero in the colon (Levitt, 1971; Glover et al., 2016) The $\mathrm{O}_{2}$ demand is highest and hypoxia tolerance is the lowest at the apical region of the villi (Vollmar et al., 2011), and the countercurrent circulatory exchanger system along the villus axis also contributes to the development of significant intestinal hypoxia, especially in lowflow states (Åhrén et al., 1973; Haglund et al., 1975).

In spite of the relatively poor $\mathrm{O}_{2}$ supply, the epithelial cells should sustain several processes with high energy demand, including, firstly, the selective absorption of nutrients. To cope with energy needs, epithelial cells are able to oxidize significant amounts of metabolites transported from the apical side, such as short-chain fatty acids and amino-acids (Blachier et al., 2009; Blouin et al., 2011).

Secondly, to maintain the function of the inter-epithelial tight junctions (TJs) and adherent junctions (AJs) of the selectively permeable mucosal barrier (Laukoetter et al., 2006; Citalan-Madrid et al., 2013; Glover et al., 2016), a continuous energy supply is needed. It has been shown in vitro that ATP depletion leads to the dissolution of TJs and AJs, but existing junctional complexes can be "reused" if ATP levels are restored within a short period of time. (Tsukamoto et al., 1997; Bush et al., 2000). Similar results were obtained in vivo. It has been shown that mesenteric ischemia and reduced mucosal ATP levels lead to TJ dysfunction and elevated permeability (Salzman et al., 1995; Wattanasirichaigoon et al., 1999). Cytosolic creatine kinase $(\mathrm{CK})$ plays an important role that covers intermittent phases of high energy demand, with the help of the cellular phosphocreatine pool, the CK-catalyzed ATP/ADP 
conversion acts as a buffer of cytocolsic phosphorylation potential (Glover et al., 2013; Kitzenberg et al., 2016).

Interestingly but not surprisingly, "physiological hypoxia" is critical for the expression of innate immune factors and TJ proteins (Kelly et al., 2013; Saeedi et al., 2015). At low $\mathrm{O}_{2}$ levels HIF- $1 \alpha$ is stabilized, leading to the gene expression of proteins critically involved in the effective barrier function (Colgan et al., 2015).

During inflammation the intestinal tissue can become profoundly hypoxic, or even anoxic despite the non-vascular origin of the disease. Contributing factors are edema, increased $\mathrm{O}_{2}$ expenditure and decreased $\mathrm{O}_{2}$ delivery to the inflamed mucosa, aggravated by the NADPH-oxidase dependent $\mathrm{O}_{2}$ consumption of extravasated PMNs (Campbell et al., 2014).

\section{Biologically active gases}

While the term "gasotransmitter" does not completely cover "biologically active gases", there is a significant overlap between the groups. Gasotransmitters are defined by four characteristics (simplicity, availability, volatility and effectiveness, respectively), and six additional criteria were recently listed by Wang (Wang, 2014). Accordingly, gasotransmitters are (1) small molecules of gas; (2) freely permeable to membranes; (3) endogenously generated in mammalian cells with specific substrates and enzymes; (4) have well-defined specific functions at physiologically relevant concentrations; (5) the functions can be mimicked by their exogenously applied counterparts; and (6) have specific cellular and molecular targets. Today the most well-known gasotransmitter compounds are $\mathrm{NO}, \mathrm{H}_{2} \mathrm{~S}$ and CO (Wang, 2014).

\subsection{Nitric oxide (NO)}

Furchgott and Zawadzki proposed the existence of an endothelium-derived vasorelaxing factor (EDRF) in 1980 (Furchgott et al., 1980), which was later identified as NO (Ignarro et al., 1987; Furchgott, 1988). Apart from vasodilation it has several physiological functions in cellular signaling, the inhibition of platelet aggregation and leukocyte adhesion (Hirst et al., 2011). Under normoxic conditions, NO is mainly produced by various NO synthase isoforms (iNOS, nNOS, eNOS) and the majority of the physiological effects are based on the activation of soluble guanylate cyclase (sGC) by binding to its heme moiety, resulting in increased cGMP levels (Toledo et al., 2012).

NO possesses an unpaired electron and is therefore regarded as a free radical. However, it is relatively stable, reacting only with other free radicals or metals and not 
forming dimers spontaneously. Its biological life-time varies (approximately 2 s under most conditions), which is extremely short for a signaling molecule but long as a free radical (most of the free radicals have a half-life of milliseconds). Being uncharged, NO readily crosses free biological membranes with passive diffusion in all directions. NO is more soluble in hydrophobic environments (by a factor of 10), which is an important determinant of its action (Thomas, 2015).

\subsection{Carbon monoxide (CO)}

$\mathrm{CO}$ is a small molecule (MW 28), non-polar gas messenger. Unlike NO, CO has no unpaired electron. Both molecules can bind to the same targets, forming complexes with hemoproteins and metalloenzymes. $\mathrm{CO}$ is produced endogenously in small quantities by a group of enzymes called heme oxigenases (Wu et al., 2005). The therapeutic application of CO has been demonstrated in various disease models (Ryter et al., 2006) and CO was successfully used in experimental transplantation to minimize IR injury as well (Ozaki et al., 2012).

\subsection{Hydrogen sulfide $\left(\mathrm{H}_{2} \mathrm{~S}\right)$}

$\mathrm{H}_{2} \mathrm{~S}$ has a structural similarity to $\mathrm{H}_{2} \mathrm{O}$. It is membrane-permeable and it can be formed both non-enzymatically and enzymatically in bacteria and mammals as well. Similar to $\mathrm{CH}_{4}$, sulfate-reducing bacteria in the human intestine are one major source of $\mathrm{H}_{2} \mathrm{~S}$. It is one of the most versatile biologically active gases, influencing an exceptionally wide range of physiological and parthophysiological processes (e.g. vascular tonus, myocardial contractility, mitochondrial OXPHOS, IR injury) (Wang, 2012).

\subsection{Methane $\left(\mathrm{CH}_{4}\right)$}

$\mathrm{CH}_{4}$ is the most reduced form of carbon, the smallest organic compound and the simplest alkane. It is odorless, colorless and occurs abundantly in the atmosphere. Because of its non-polar properties, the solubility of $\mathrm{CH}_{4}$ is two orders of magnitude higher in membrane lipids than in the aqueous phase (Miller et al., 1977; Meyer et al., 1980). $\mathrm{CH}_{4}$ is not toxic per $s e$, but a simple asphyxiant, which means that by displacing $\mathrm{O}_{2}$ in closed spaces hypoxia can develop. It should be stressed that, in physiologically relevant concentrations $\mathrm{CH}_{4}$ has no toxic effects, unless $\mathrm{O}_{2}$ delivery is heavily compromised. Under ambient conditions $\mathrm{CH}_{4}$ is accepted to be not reactive, but in the troposphere $\mathrm{CH}_{4}$ is oxidized to $\mathrm{CO}_{2}$ by hydroxyl radicals (formed by the photoreaction of tropospheric ozone and water vapor) (Cantrell et al., 1990; Hurkuck et al., 2012). 


\subsubsection{Bacterial and non-bacterial origin of $\mathrm{CH}_{4}$ in mammals}

In the GI system of most mammals, especially in ruminants, large amounts of carbohydrates are fermented. $\mathrm{CO}_{2}$ released during this process is subsequently reduced to $\mathrm{CH}_{4}$ by the obligate anaerobe prokaryotes, the methanogenic Archaea (Conrad et al., 1999). The rate-limiting last step of $\mathrm{CO}_{2}$ oxidation is catalyzed by methyl coenzyme $\mathrm{M}$ reductase (EC 2.8.4.1) (Wongnate et al., 2015). The gas produced is then excreted with the flatus, leaves through the skin or can be measured in roughly one third of humans in the exhaled breath (Nose et al., 2005; de Lacy Costello et al., 2013).

The non-microbial formation of $\mathrm{CH}_{4}$ in eukaryotic mitochondria was first demonstrated in vitro in 2003 (Ghyczy et al., 2003). It was later shown that during oxidoreductive stress conditions in animal and plant cell cultures and also in vivo, measurable quantities of $\mathrm{CH}_{4}$ are formed (Ghyczy et al., 2008; Wishkerman et al., 2011; Keppler et al., 2016). Possible ways of in vivo (bio)chemical reactions that are able to produce $\mathrm{CH}_{4}$ were reviewed recently (Boros et al., 2015).

\subsubsection{Biological effects}

Much attention has recently been paid to the bioactivity of $\mathrm{CH}_{4}$ in eukaryotes and to its possible therapeutic projections. The biological effect of $\mathrm{CH}_{4}$ in the mammalian organism was first shown by Pimentel and colleagues (Pimentel et al., 2006). They reported that $\mathrm{CH}_{4}$ slows the small intestinal propulsive motility and augments contractile activity, thereby influencing the enteral nervous/smooth muscle system. Correlations of detectable $\mathrm{CH}_{4}$ in the exhaled air of humans and peristalsis changes during irritable bowel syndrome have been repeatedly shown as well (Lee et al., 2013; Pozuelo et al., 2015).

An anti-inflammatory potential for $\mathrm{CH}_{4}$ was first reported by Boros and colleagues in experimental mesenteric IR (Boros et al., 2012). Over the past few years many other papers have been published on the anti-inflammatory effects of $\mathrm{CH}_{4}$ in various animal models of IR, hypoxia and sterile inflammation (see Table 2). Most publications addressed four aspects of $\mathrm{CH}_{4}$ activity, namely (1) the modulation of pro-inflammatory cytokine release (TNF- $\alpha$, IFN- $\gamma$, IL-6 and IL-1b); (2) anti-apoptotic effects evidenced by the reduced number of apoptotic cells, normalized caspase-3 and caspase- 9 activity, decreased Bax and increased Bcl-2 levels and/or gene expression; (3) the suppressed generation of oxidative stress biomarkers (malondialdehyde, 8-oxo-2'-deoxyguanosine, 4-hydroxynonenal) with concurrent potentiating of endogenous antioxidant systems (superoxide dismutase, catalase, glutathione peroxidase); and (4) improved organ functions. The key publications on the subject are summarized below (Table 1). 


\begin{tabular}{|c|c|c|}
\hline Topics & Source & Main findings \\
\hline IR injury of skin & Song K et al. 2015 BMC Surgery & $\begin{array}{l}\mathrm{CH}_{4} \text {-rich saline attenuates the IR injury of } \\
\text { abdominal skin flaps in rats }\end{array}$ \\
\hline Diabetic retinopathy & Wu J et al. 2015 BBRC & $\begin{array}{l}\text { Protective effects of } \mathrm{CH}_{4} \text {-rich saline on retinopathy } \\
\text { in a streptozotocin-induced diabetic rat model }\end{array}$ \\
\hline Liver IR injury & Ye Z et al. 2015 Shock & $\begin{array}{l}\mathrm{CH}_{4} \text { attenuates hepatic IR injury in rats through } \\
\text { antiapoptotic and antioxidative actions }\end{array}$ \\
\hline Liver IR injury & Strifler et al. 2016 PLOS One & $\begin{array}{l}\text { Inhaled } \mathrm{CH}_{4} \text { limits the mitochondrial electron } \\
\text { transport chain dysfunction during experimental } \\
\text { liver IR injury }\end{array}$ \\
\hline $\begin{array}{l}\text { Myocardial IR } \\
\text { injury }\end{array}$ & Chen $\mathrm{O}$ et al. 2016 FRBM & $\begin{array}{l}\mathrm{CH}_{4} \text { attenuates myocardial ischemia injury in rats } \\
\text { through anti-oxidative, anti-apoptotic and anti- } \\
\text { inflammatory actions }\end{array}$ \\
\hline $\begin{array}{l}\text { Concanavalin A- } \\
\text { induced hepatitis }\end{array}$ & He R et al. 2016 BBRC & $\begin{array}{l}\mathrm{CH}_{4} \text {-rich saline protects against concanavalin A- } \\
\text { induced autoimmune hepatitis in mice through anti- } \\
\text { inflammatory and anti-oxidative pathways }\end{array}$ \\
\hline Exhaustive exercise & Xin L et al. 2016 PLOS One & $\begin{array}{l}\mathrm{CH}_{4} \text {-rich saline influences stress induced by one- } \\
\text { time exhaustive exercise in rats }\end{array}$ \\
\hline $\begin{array}{l}\text { Neuroprotection in } \\
\text { acute CO poisoning }\end{array}$ & Fan D et al. 2016 Brain Res & $\begin{array}{l}\text { Neuroprotective effects of exogenous } \mathrm{CH}_{4} \text { in a rat } \\
\text { model of acute carbon monoxide poisoning }\end{array}$ \\
\hline Retinal IR injury & Liu L et al. 2016 Brain Res & $\begin{array}{l}\mathrm{CH}_{4} \text { attenuates retinal IR injury via anti-oxidative } \\
\text { and anti-apoptotic pathways }\end{array}$ \\
\hline $\begin{array}{l}\text { LPS-induced } \\
\text { immune response }\end{array}$ & Zhang X et al. 2016 Sci Rep & $\begin{array}{l}\mathrm{CH}_{4} \text { limits LPS-induced NF- } \kappa \mathrm{B} / \mathrm{MAPKs} \text { signal in } \\
\text { macrophages and suppresses immune response in } \\
\text { mice by enhancing PI3K/AKT/GSK-3 } \beta \text {-mediated } \\
\text { IL-10 expression }\end{array}$ \\
\hline Acute CO toxicity & Shen M et al. 2016 J Neurol Sci & $\begin{array}{l}\text { Neuroprotective effects of } \mathrm{CH}_{4} \text {-rich saline on } \\
\text { experimental acute } \mathrm{CO} \text { toxicity }\end{array}$ \\
\hline
\end{tabular}

Table 1. Recent publications on $\mathrm{CH}_{4}$ bioactivity

\subsection{Relationship between $\mathrm{O}_{2}$ and other gases}

Disturbances in macro- and microcirculation either by primarily vascular origin or during secondary inflammatory disorders can profoundly alter the oxygenation profile of tissues. Many of the endogenous enzymes that utilize $\mathrm{O}_{2}$ are able to bind other gases as well, but often with lower affinity. The complex interplay of gaseous compounds is of particular importance in hypoxic pathologies, since in the lack of $\mathrm{O}_{2}$ new reactions can emerge, highlighting those processes which are usually in the background. A well-explored area of such interactions is that of $\mathrm{O}_{2}$ with $\mathrm{NO}$ (van Faassen et al. 2009).

\section{NO-linked effects in hypoxia}

NO production by the NOS isoforms is an $\mathrm{O}_{2}$-dependent mechanism. Under hypoxic and anoxic conditions $\mathrm{NO}$ can be formed from nitrite $\left(\mathrm{NO}_{2}{ }^{-}\right)$and from nitrate $\left(\mathrm{NO}_{3}{ }^{-}\right)$, with further reduction through $\mathrm{NO}_{2}^{-}$. The main $\mathrm{NO}_{2}^{-}$reductases in humans are as follows. 
- XOR. The majority of Mo-containing enzymes are bacterial proteins (Hille 2013). There are four known Mo-containing enzymes in mammals and all four can act as $\mathrm{NO}_{2}{ }^{-}$ reductase, namely XOR, sulfite oxidase, aldehyde oxidase and mitochondrial amidoxime reductase (Sparacino-Watkins et al., 2014; Maia et al., 2015; Wang et al., 2015). Especially in the intestine and in the liver, XOR has multiple roles during hypoxia and reoxygenation (ROS production by XOR during the reperfusion has been reviewed before in section 2.2), but a crucial catalytic activity of the enzyme is the reduction of $\mathrm{NO}_{2}{ }^{-}$to NO. XOR is structurally similar to bacterial $\mathrm{NO}_{2}{ }^{-} / \mathrm{NO}_{3}{ }^{-}$reductases (Zhang et al., 1998), and the $\mathrm{NO}_{2}{ }^{-}$reductase activity of $\mathrm{XO}$ is increases with acidosis and in hypoxic conditions (Hassoun et al., 1994; Kayyali et al., 2001).

- Direct uncatalyzed reduction occurs at measurable rates in the stomach at low $\mathrm{pH}$ (and perhaps in ischemic tissues) (Lundberg et al., 1994).

- Deoxygenated forms of $\mathbf{H b}$ (and $\mathrm{Mb}$ ) are allosterically regulated $\mathrm{NO}_{2}{ }^{-}$reductases. $\mathrm{Hb}$ produces the NO with the highest rate at the half-loading point of $\mathrm{O}_{2}$ (about $35 \mu \mathrm{M}$ ) (Huang et al., 2005). The rate of $\mathrm{NO}_{2}{ }^{-}$reduction is dependent on the $\mathrm{O}_{2}$ tension: with higher $\mathrm{O}_{2}$ concentrations more $\mathrm{Hb}$ is saturated and the number of available ferrous hemes for NO decreases.

- Mitochondrial respiratory chain complexes III and IV can act as $\mathrm{NO}_{2}^{-}$reductases as well (Kozlov et al., 1999). Having a negative charge, $\mathrm{NO}_{2}{ }^{-}$cannot diffuse freely into mitochondria, and only a fraction of cytoplasmic $\mathrm{NO}_{2}{ }^{-}$is available intramitochondrially in the form of $\mathrm{HNO}_{2}$ (Samouilov et al., 2007).

The NO formation from $\mathrm{NO}_{2}{ }^{-}$under hypoxia is viewed as a salvage mechanism, as under such conditions physiological $\mathrm{NO}_{2}^{-}$concentrations are already sufficient to induce vasorelaxation (Dalsgaard et al., 2007).

\section{NO and reperfusion}

- $\mathrm{NO}_{2}{ }^{-}$-dependent cytoprotection was repeatedly shown in various IR models (Webb et al., 2004; Duranski et al., 2005; Jung et al., 2006; Tripatara et al., 2007). NO is able to inhibit cell surface adhesion molecules both on endothelial cells and leukocytes, thereby preventing extravasation and the activation of PMNs (De Caterina et al., 1995). Furthermore, by the S-nitrosation of inflammatory transcription factors (e.g. activator

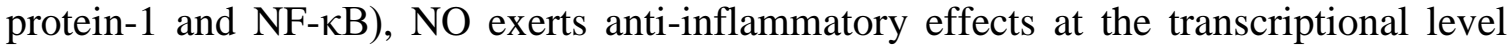
(Pilz et al., 1995).

- S-nitrosation (one electron oxidation of a thiol group to form S-NO) of proteins and peptides leads to the formation of S-nitosothiols (RSNOs) (Stamler et al., 1992; Jia et al., 
1996), a cGMP-independent signaling pathway of NO. The RSNOs formed are stable and can act as NO donor molecules. Reactive nitrogen species support the formation of RSNOs. On the other hand, in vitro evidence suggests that $\mathrm{XO}$-derived $\mathrm{O}_{2}{ }^{\bullet-}$ is able to decompose RSNO and lead to ONOO formation (Trujillo et al., 1998).

- Peroxynitrite (ONOO) formation and the deleterious effects of NO are mostly connected. ONOO is an oxidant species formed in the diffusion-controlled reaction of NO with $\mathrm{O}_{2}{ }^{\bullet-}$ (Beckman et al., 1990). XOR producing $\mathrm{NO}$ under hypoxia and $\mathrm{O}_{2}{ }^{\bullet-}$ in the postischemic tissue may be an important source of ONOO (Godber et al., 2000). ONOO and ONOO-derived radicals (e.g. lipid hydroperoxides) can readily oxidize and/or nitrate biomolecules including tyrosine residues, thiols, DNA and unsaturated fatty-acidcontaining phospholipids. Irreversible tyrosine nitration at CI is a well known adverse effect of ONOO (Brown et al., 2004), whereas high ONOO concentrations lead to generalized protein and lipid modifications (Gadelha et al., 1997; Szabo et al., 2007).

\section{Mitochondrion: the hub of interactions of gaseous compounds}

While not much is known about the interactions between various gases in the eukaryotic cells, the importance of the topic is increasingly recognized. Protein complexes of the ETS are partially embedded in the IMM, exposing parts of them to the lipid bilayer and, therefore, to the apolar milieu. This is an important point to consider, since some of the most abundant gas mediators (e.g. NO) are far more soluble in lipids than in the aqueous phase. The mitochondrial ETS, particularly cytochrome c oxidase (CIV), is the target of the whole machinery of aerobe organisms which seek to at transport molecular $\mathrm{O}_{2}$. This enzyme catalyzes the reduction of $\mathrm{O}_{2}$ by ferrycytochrome to $\mathrm{H}_{2} \mathrm{O}$; hence it is quite predictable that other gases can interact with it as well. Indeed, $\mathrm{CO}, \mathrm{NO}, \mathrm{H}_{2} \mathrm{~S}$ and $\mathrm{HCN}$ all inhibit CIV (Cooper et al., 2008). More importantly, it has been shown that CIV inhibition by sodium azide leads to endogenous $\mathrm{CH}_{4}$ generation in plant cells and mammals (Wishkerman et al., 2011; Tuboly et al., 2013b). Furthermore, it has been shown that $\mathrm{CH}_{4}$ inhalation improved mitochondrial OXPHOS in a partial hepatic IR model, at least indirectly (Strifler et al., 2016).

If $\mathrm{O}_{2}$ levels are in the physiologic range, the affinity of NO for sGC is about 50 times higher than that for the cytochrome c oxidase (data from brain tissue at $\mathrm{O}_{2}$ levels of $30 \mu \mathrm{M}$ (Brown et al., 1994)). However, with lower $\mathrm{O}_{2}$ concentrations this apparent gap decreases and $\mathrm{NO}$ inhibits CIV in competition with $\mathrm{O}_{2}$.

Usually, the reduction of molecular $\mathrm{O}_{2}$ at CIV is not rate-limiting in mitochondrial respiration, but the partial inhibition of CIV by one gas will make it more rate limiting for 
respiration, and in consequence more sensitive to other gases (Cooper et al., 2008). Quite significantly, hypoxia is an inhibitor of CIV as well. Therefore, under hypoxic conditions, the inhibitory effects exerted by other gases can be amplified. The $\mathrm{K}_{\mathrm{M}}$ of CIV is about $0.5 \mu \mathrm{M}$ of $\mathrm{O}_{2}$, well below the $\mathrm{O}_{2}$ levels in the body; hence CIV is not rate-limited. (We should mention here that because of the physiologically low tissue $\mathrm{O}_{2}$ levels in the intestine, the mitochondria there might be prone to interactions with other gases). In contrast, if $60 \mathrm{nM}$ of $\mathrm{NO}$ is present, $\mathrm{K}_{\mathrm{M}}$ of $\mathrm{O}_{2}$ rises to $30 \mu \mathrm{M}$, well above $\mathrm{O}_{2}$ levels in the intestine (Brown et al., 1994). In most cases, the reciprocal control of $\mathrm{O}_{2}$ and $\mathrm{NO}$ relieves inhibition. Under profound ischemia, however, vasodilation is ineffective and compensatory mechanisms fail to replenish $\mathrm{O}_{2}$ to mitochondria, resulting in gradually increasing NO concentrations.

Under physiological conditions, when an excess capacity of OXPHOS is present, the partial inhibition of CIV by NO may operate in parallel with ATP production matching the needs of the cell, while providing a "regulated" ROS formation for signal transduction. The term "nitroxia" was suggested by Shiva and coworkers for a dysregulated state, having some of the characteristics of hypoxia, when excess NO substantially inhibits CIV, leading to ATP depletion despite sufficient $\mathrm{O}_{2}$ levels. In this case, enhanced ROS formation can be measured (Shiva et al., 2005).

It is recognized that gaseous compounds are able to interact with other components of the mitochondrial electron transport machinery as well. The inhibition of CI by S-nitrosation is thought to be beneficial, protecting downstream complexes from pathologically increased ROS production under reperfusion (Brown et al., 2004; Shiva et al., 2009). Another mitochondrial target of gases is cytochrome c; $\mathrm{CO}, \mathrm{NO}$ and $\mathrm{H}_{2} \mathrm{~S}$ can also interact with this hemoprotein with different degrees of affinity. Notably, interactions of cytochrome $\mathrm{c}$ with cardiolipin, a component of the IMM, dramatically enhance the ligand interactions of cytochrome c, so gas interactions are far more likely (Kagan et al., 2005; Vlasova et al., 2006).

Interestingly, p66Shc, an alternatively spliced transcript from the SHC1 gene, can produce ROS acting as an oxidoreductase and can transfer electrons from mitochondrial cytochrome c to $\mathrm{O}_{2}$ (Giorgio et al., 2005). The role of mitochondrial p66Shc was postulated in the ROS-induced ROS release (Zorov et al., 2000; Galimov et al., 2014), ultimately leading to the induction of mitochondrial permeability transition. How the binding of gas molecules to cytochrome $\mathrm{c}$ influences this process has not yet been explored.

Apart from reversible interactions of gases with mitochondrial enzymes, ONOO can inhibit CI, CII, CIV, ATP synthase, aconitase, Mn-SOD, creatine kinase, and probably many 
other mitochondrial proteins in an uncontrolled manner (Cassina et al., 1996; Gadelha et al., 1997). This obviously harmful consequence of pathologically elevated mtROS and NO levels can only be prevented by the timely inhibition of abnormal ROS and NO production.

The interplay of $\mathrm{CH}_{4}$ with $\mathrm{NO}$ in mammals has not yet been investigated systematically. On the one hand, it was demonstrated that normoxic $\mathrm{CH}_{4}$ ventilation decreases tyrosine nitrosylation after an IR injury (Boros et al., 2012), a process which involves NO. On the other hand, it has been shown that the inhibition of CIV, an important target of NO under hypoxia, leads to $\mathrm{CH}_{4}$ generation (Wishkerman et al., 2011; Tuboly et al., 2013b). It should be added that the heme $\mathrm{a} 3 / \mathrm{CuB} \mathrm{O}_{2}$ reduction site of CIV is hydrophobic (Wikstrom, 2004), increasing the probability of interaction with gases that are more soluble in lipids than in the water phase. Moreover, some of the effects exerted by $\mathrm{CH}_{4}$ in model systems of inflammation can be explained by the indirect modulation of functions of NO. It is likely that the two gases are able to modulate the effect of each other at membrane interfaces, where their concentration is at its peak. The reaction of $\mathrm{NO}$ with $\mathrm{O}_{2}$ in hydrophobic membranes thought to be faster than in the aqueous phase. Based on model calculations, even with only $3 \%$ of lipids in the tissue volume, the majority of reactions of $\mathrm{NO}$ with $\mathrm{O}_{2}$ will occur within membranes (Liu et al., 1998). Taking into account the solubility of $\mathrm{CH}_{4}$, comparable changes can be estimated. 


\section{Aims}

1. Our first general aim was to explore the consequences and effects of normoxic $\mathrm{CH}_{4}$ administration in a small animal model of IR-induced inflammation; the following specific goals have been addressed.

- The first specific goal was to characterize the changes in epithelial and endothelial permeabilities induced by IR challenge in the rat small intestine. With this aim, we monitored the early and later biochemical consequences, the structural and hemodynamic changes in the intestinal mucosa;

- The second goal was to detect specific biochemical markers of both oxidative and nitrosative stress to investigate the possible mechanism of action of exogenous $\mathrm{CH}_{4}$ based treatments;

- The third goal is based on our hypothesis that $\mathrm{CH}_{4}$ has direct influence on cell membrane rigidity. Therefore an additional goal was to investigate the influence of $\mathrm{CH}_{4}$ on changes in erythrocyte deformability provoked by oxidative stress in vitro.

2. Our second general aim was to better understand the mechanisms of $\mathrm{CH}_{4}$ action in models of tissue hypoxia with elevated ROS and RNS levels, with special emphasis on the possible relationship of $\mathrm{CH}_{4}$ with other biological gases, such as NO; the following specific goals have been addressed in this part of the study.

- $\quad$ The first goal was to establish a bacterial endotoxin-based in vivo experimental model of inflammation to follow the changes in locally generated NO levels;

- The second goal was to develop a specific and sensitive method to detect NO generation in the model established in the first goal;

- The third goal was to examine the potential interplay of $\mathrm{CH}_{4}$ with $\mathrm{NO}$ directly investigating in vivo and ex vivo effects of $\mathrm{CH}_{4}$ administrations on the rates of NO generation in biological samples by means of electron paramagnetic resonance (EPR) spectroscopy technique and on-line chemiluminescence analyses. 


\section{Materials and methods}

\section{An in vivo study to investigate the effects of $\mathrm{CH}_{4}$ treatments in mesenteric IR}

\subsection{Animals}

The experiments were performed on 76 male Sprague-Dawley rats (280-320 g bw) in accordance with National Institutes of Health guidelines on the handling and care of experimental animals and EU Directive 2010/63 for the protection of animals used for scientific purposes, and it was approved by the National Scientific Ethical Committee on Animal Experimentation (National Competent Authority), with the license number $\mathrm{V} / 148 / 2013$. The animals were housed in plastic cages under 12/12 $\mathrm{hr}$ day-night cycle, standard air temperature and humidity conditions. All chemicals were obtained from SigmaAldrich Inc. (Budapest, Hungary) unless otherwise stated.

\subsection{Surgical procedure and study design}

Rats fed on a normal laboratory diet with tap water ad libitum, were randomly allocated into one or other of the experimental groups. After overnight fasting, the animals were anaesthetized with sodium pentobarbital $(50 \mathrm{mg} / \mathrm{kg} \mathrm{bw} \mathrm{ip)} \mathrm{and} \mathrm{placed} \mathrm{in} \mathrm{a} \mathrm{supine} \mathrm{position} \mathrm{on}$ a heating pad. The trachea was dissected free and cannulated with a silicone tube, and the right jugular vein was cannulated with PE50 tubing for fluid administration and infusion of Ringer's lactate $(10 \mathrm{~mL} / \mathrm{kg} / \mathrm{h})$ during the experiments.

The experiments were performed in two series (see Figure 1). In study 1 (the "early reperfusion" study), the animals were killed $60 \mathrm{~min}$ after the re-establishment of the mesenteric blood flow, while in the second set (the "late reperfusion" study), the reperfusion period and the corresponding control phase in the sham-operated animals lasted for $180 \mathrm{~min}$.

After a midline laparotomy, the superior mesenteric artery (SMA) was dissected free. Group $1(n=6)$ served as a sham-operated control, while in Group 2 (IR, $n=6)$ the SMA was occluded using an atraumatic vascular clip for $45 \mathrm{~min}$. $\mathrm{In} \mathrm{CH}_{4}$-treated Group $3\left(\mathrm{IR}+\mathrm{CH}_{4}, \mathrm{n}=6\right)$ an artificial gas mixture containing $2.2 \% \mathrm{CH}_{4}, 21 \% \mathrm{O}_{2}$ and $76.8 \% \mathrm{~N}_{2}$ (Linde Gas, Budapest, Hungary) was administered for 5 min before the end of the 45-min ischemia and for $10 \mathrm{~min}$ at the beginning of the reperfusion (Figure 1). In study 2 the protocol followed was identical, but the length of the observation and the reperfusion phase was different. 


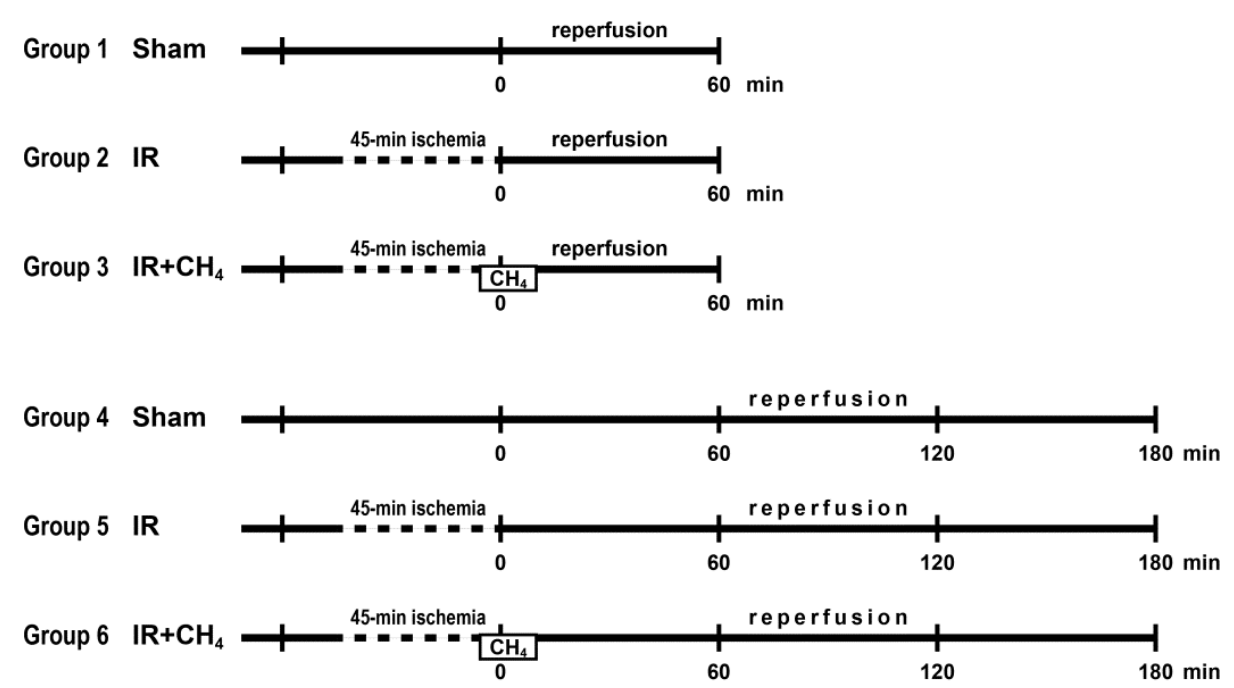

Figure 1. Experimental scheme

\subsection{Mucosal permeability measurements}

The epithelial permeability was determined with the $4 \mathrm{kDa}$ fluorescein isothiocyanatedextran (FD4) method as described previously (Cuzzocrea et al., 1997). In short, a $5 \mathrm{~cm}$ long segment of the terminal ileum supplied by 3 blood vessel arcades was isolated at a distance of $10 \mathrm{~cm}$ from the ileocecal valve. Silicone cannulas were placed and fixed into the oral and aboral ends of the segment and the lumen was gently flushed with $5 \mathrm{~mL}$ of $37^{\circ} \mathrm{C}$ saline and 5 $\mathrm{mL}$ air, then the distal end was closed. Before performing measurements, the renal pedicles were ligated. Exactly at the moment of reperfusion (the "early reperfusion" study) or $120 \mathrm{~min}$ after (the "late reperfusion" study), the lumen was filled with $0.5 \mathrm{~mL}$ of warmed $\left(37^{\circ} \mathrm{C}\right) \mathrm{FD} 4$ solution $(25 \mathrm{mg} / \mathrm{mL})$. Blood samples $(0.3 \mathrm{~mL})$ were then taken 5, 10, 20, 30 and $40 \mathrm{~min}$ later for plasma fluorescein concentration measurements with a fluorescence spectrophotometer (F2000 Hitachi, Japan, Ex: 492 nm; Em: 515 nm). The blood samples were stored on ice in the dark and centrifuged at $100 \mathrm{~g}$ for $10 \mathrm{~min}$. At the end of the experiment, the bowel segment was removed and weighed. The epithelial permeability index was expressed as a percentage of FD4 measured in the plasma and it was calculated using the formula [arterial FD4 concentration (ng/mL) / luminal FD4 concentration $(\mathrm{ng} / \mathrm{mL})] * 100$.

The vascular permeability index was determined using the azo dye Evans blue method as described previously (Szentpali et al., 2001). Stated briefly, $30 \mathrm{~min}$ before the end of the experiments $20 \mathrm{mg} / \mathrm{mL} / \mathrm{kg}$ of Evans blue was given in iv bolus and $30 \mathrm{~min}$ later a blood sample was taken from the caval vein, together with a whole-thickness tissue sample from the ileum. The biopsy specimen was placed in $5 \mathrm{~mL}$ of formamide and homogenized for $1 \mathrm{~min}$ in a glass Potter homogenizer. The homogenate was incubated at room temperature for $20 \mathrm{~h}$ and 
then centrifuged at $2500 \mathrm{~g}$ for $30 \mathrm{~min}$. The absorbance of the supernatant was determined at $650 \mathrm{~nm}$ against a formamide blank with a UV-1601 spectrophotometer (Shimadzu, Japan). The concentration of Evans blue was determined from a standard curve and it was normalized to the protein content of the samples (Lowry et al., 1951). Similarly, blood samples were centrifuged at $600 \mathrm{~g}$ at $4^{\circ} \mathrm{C}$ for $10 \mathrm{~min}$ and the absorbance of the 100 -fold-diluted plasma was measured. The vascular permeability index was defined as the ratio of the tissue and plasma concentrations of Evans blue, i.e.[tissue Evans blue concentration / plasma Evans blue concentration] $* 100$.

\subsection{Morphological analysis}

\section{Histopathological analysis}

Full-thickness ileum biopsies were taken after $30 \mathrm{~min}$ of reperfusion in each group. The tissue was rinsed in ice-cold saline, fixed in $10 \%$ buffered formalin, embedded in paraffin, cut into $4 \mu \mathrm{m}$-thick sections, and stained with hematoxylin and eosin. Photomicrographs were recorded with a 40x objective connected to a digital camera.

\section{In vivo histology}

The extent of superficial epithelial damage of the terminal ileum was evaluated by means of fluorescence confocal laser scanning endomicroscopy (CLSEM, Five1 Optiscan Pty. Ltd, Melbourne, Victoria, Australia) developed for in vivo histology. The mucosal surface of the terminal ileum $10 \mathrm{~cm}$ proximal to the cecum was exposed surgically and laid flat for examination. The injury of the mucosal architecture was examined after topical application of the fluorescent dye acriflavin. The surplus dye was washed off with saline, then the objective of the device was placed onto the mucosal surface of the ileum, and confocal imaging was performed 2 min after dye administration (1 scan per image, $1024 \times 1024$ pixels and $475 \times$ $475 \mathrm{~mm}$ per image). Non-overlapping fields were processed and evaluated by a modified semiquantitative scoring system (Érces et al., 2016). The grading was performed using five criteria: I. denudation of villi $(0=$ no denudation, $1=$ at least one denuded area per field of view, 2 = more than one area without any recognizable villus structure per field of view; II. edema $(0=$ no edema, $1=$ moderate epithelial swelling, $2=$ severe edema $)$; III. shedding $(0=$ a normal, clearly, well-defined villus structure without shedding cells, $1=$ some shedding cells; fewer than 30 cells per field of view, 2 = shedding cells, more than 30 cells per field of view, 3 = severe debris); IV. epithelial gap ( $0=$ no gap, $1=$ less than 5 gaps per villi, $2=$ more than 5 gaps per villi); V. longitudinal fissure on villi $(0=$ no fissure, $1=$ presence of fissure). A blinded analysis of the same images was performed twice off-line. 


\subsection{Hemodynamics}

The SMA flow signals (T206 Animal Research Flowmeter; Transonic Systems Inc, Ithaca, NY, USA) were measured continuously and recorded with a computerized data acquisition system (Experimetria Ltd, Budapest, Hungary).

An intravital orthogonal polarization spectral imaging technique (Cytoscan A/R, Cytometrics, Philadelphia, PA, USA) was used for the visualization of the serosal microcirculation of the ileum. This technique uses reflected polarized light at the wavelength of the isosbestic point of oxyhemoglobin and deoxyhemoglobin (548 nm). Because polarization is preserved in reflection, only photons scattered from a depth of $200 \mathrm{~mm}$ contribute to image formation. A 10x objective was placed onto the serosal surface of the ileum, and microscopic images were recorded with an S-VHS video recorder (Panasonic AGTL 700, Matsushita Electric Ind. Co. Ltd, Osaka, Japan). The quantitative assessment of the microcirculatory parameters was performed off-line by a frame-to frame blinded analysis of the videotaped images. Changes in red blood cell $(\mathrm{RBC})$ velocity $(\mathrm{mm} / \mathrm{s})$ in the postcapillary venules were determined in 3 separate fields by means of a computer-assisted image analysis system (IVM Pictron, Budapest, Hungary). All microcirculatory evaluations were performed by the same investigator.

\subsection{Biochemical measurements}

Ileum biopsies kept on ice were homogenized in a phosphate buffer ( $\mathrm{pH}$ 7.4) containing Tris-HCl (50 mM, Reanal, Budapest, Hungary), EDTA (0.1 mM), dithiotreitol (0.5 mM), phenylmethylsulfonyl fluoride $(1 \mathrm{mM})$, soybean trypsin inhibitor $(10 \mu \mathrm{g} / \mathrm{mL})$ and leupeptin $\left(10 \mu \mathrm{g} / \mathrm{mL}\right.$ ). The homogenate was centrifuged at $4^{\circ} \mathrm{C}$ for $20 \mathrm{~min}$ at $24000 \mathrm{~g}$ (Amicon Centricon-100, Millipore Corporation, Bedford, Massachusetts, USA). Tissue nitrotyrosine (NTyr) concentration was determined in the supernatant, while myeloperoxidase (MPO) activity was measured in the pellet of the homogenate.

\section{Tissue myeloperoxidase (MPO) activity}

The activity of MPO as a marker of tissue leukocyte infiltration was measured in the pellet of the homogenate using the modified method of Kübler et al. (Kuebler et al., 1996). Stated briefly, the pellet was resuspended in $\mathrm{K}_{3} \mathrm{PO}_{4}$ buffer $(0.05 \mathrm{M} ; \mathrm{pH} 6.0)$ containing $0.5 \%$ hexa-1,6-bis-decyltriethylammonium bromide. After three repeated freeze-thaw procedures, the material was centrifuged at $24000 \mathrm{~g}$ at $4^{\circ} \mathrm{C}$ for $20 \mathrm{~min}$ and the supernatant was used for MPO determination. Afterwards, $0.15 \mathrm{~mL}$ of 3,3',5,5'-tetramethylbenzidine (dissolved in DMSO; $1.6 \mathrm{mM}$ ) and $0.75 \mathrm{~mL}$ of hydrogen peroxide (dissolved in $\mathrm{K}_{3} \mathrm{PO}_{4}$ buffer; $0.6 \mathrm{mM}$ ) were added to $0.1 \mathrm{~mL}$ of the sample. The reaction led to the hydrogen peroxide-dependent 
oxidation of tetramethylbenzidine, which was detected spectrophotometrically at $450 \mathrm{~nm}$ (UV-1601 spectrophotometer; Shimadzu, Kyoto, Japan). MPO activities were measured at $37^{\circ} \mathrm{C}$; the reaction was stopped after $5 \mathrm{~min}$ by the addition of $0.2 \mathrm{~mL}$ of $\mathrm{H}_{2} \mathrm{SO}_{4}(2 \mathrm{M})$ and the resulting data were normalized to the protein content.

\section{Plasma ET-1 levels}

Blood samples $(0.5 \mathrm{~mL})$ were taken from the inferior caval vein and placed into chilled polypropylene tubes containing EDTA $(1 \mathrm{mg} / \mathrm{mL})$ at the end of the "late reperfusion" experiments (180 min after reperfusion), centrifuged at $1000 \mathrm{~g}$ at $4^{\circ} \mathrm{C}$ for $30 \mathrm{~min}$ and then stored at $-70^{\circ} \mathrm{C}$ until assay. The plasma ET-1 concentration was determined in duplicates by means of a commercially available enzyme-linked immunosorbent assay (ELISA) kit (Biochemica Hungaria Ltd., Budapest, Hungary) and expressed as fmol/mL.

\section{Intestinal $\mathrm{O}_{2}^{\bullet-}$ production}

The rate of $\mathrm{O}_{2}^{\bullet-}$ production in freshly minced intestinal biopsy samples was assessed by using the lucigenin-enhanced chemiluminescence assay described by Ferdinandy et al. (Ferdinandy et al., 2000) In short, approx. $10 \mathrm{mg}$ of intestinal tissue was placed in $1 \mathrm{~mL}$ of Dulbecco's solution ( $\mathrm{pH}$ 7.4) containing $5 \mu \mathrm{M}$ of lucigenin. The manipulations were performed without external light $2 \mathrm{~min}$ after dark adaptation. Chemiluminescence was measured at room temperature in a liquid scintillation counter by using a single active photomultiplier positioned in out-of-coincidence mode, in the presence or absence of the $\mathrm{O}_{2}{ }^{\bullet-}$ scavenger nitroblue tetrazolium (NBT; $20 \mu \mathrm{l}$ ). NBT-inhibited chemiluminescence was interpreted as an indicator of intestinal $\mathrm{O}_{2}{ }^{\bullet-}$ generation.

\section{Tissue nitrotyrosine level}

Free NTyr, as a marker of ONOO generation, was measured by an enzyme-linked immunosorbent assay (Cayman Chemical; Ann Arbor, MI). Small intestinal tissue samples were homogenized and centrifuged at $15000 \mathrm{~g}$. The supernatants were collected and incubated overnight with anti-NTyr rabbit IgG and a NTyr acetylcholinesterase tracer in precoated (mouse anti-rabbit IgG) microplates, which were developed using Ellman's reagent. The NTyr content was normalized to the protein content of the small intestinal homogenate and expressed in $\mathrm{ng} / \mathrm{mg}$.

\section{7. $\mathrm{CH}_{4}$ concentration measurement}

The $\mathrm{CH}_{4}$ concentration was measured by means of photoacoustic spectroscopy (PAS) (Tuboly et al., 2013a). PAS is a special type of spectroscopy that measures optical absorption indirectly via the conversion of absorbed light energy into acoustic waves. The amplitude of the generated sound is directly proportional to the concentration of the absorbing gas 
component. The light source of the system is a near-infrared diode laser that emits around the $\mathrm{CH}_{4}$ absorption line at $1650.9 \mathrm{~nm}$ with an output power of $15 \mathrm{~mW}$ (NTT Electronics, Tokyo, Japan). The cross-sensitivity for common components of breath and ambient air were repeatedly examined, and no measurable instrument response was found for significant concentrations of $\mathrm{CO}_{2}$ or $\mathrm{H}_{2} \mathrm{O}$ vapour. The narrow line width of the diode laser provides high selectivity; the absorbance of $\mathrm{CH}_{4}$ is several orders of magnitude greater than that of $\mathrm{H}_{2} \mathrm{O}$, $\mathrm{CO}_{2}$ or $\mathrm{CO}$ at $1.65 \mu \mathrm{m}$, the wavelength we used. The $\mathrm{CH}_{4}$ values were corrected for background levels and expressed in parts-per-million (ppm).

The device was previously calibrated with various gas mixtures prepared by the dilution of 1 vol $\%$ of $\mathrm{CH}_{4}$ in synthetic air, and it has a dynamic range of 4 orders of magnitude; the minimum online detectable concentration of the sensor was found to be $0.25 \mathrm{ppm}(3 \sigma)$, with an integration time of $12 \mathrm{~s}$ (Tuboly et al. 2013).

In a separate set of experiments, tissue $\mathrm{CH}_{4}$ concentration was measured multiple times in anesthetized rats after the inhalation of room air or artificial air containing $2.2 \%$ exogenous $\mathrm{CH}_{4}$. Immediately after $15 \mathrm{~min}$ of inhalation, a $200 \mathrm{mg}$ ileum sample was taken, excess fluid was immediately wiped off and the tissue specimen was placed in a glass vial with $20 \mathrm{~mL}$ headspace volume and closed so as to be air tight. Parallel to taking ileum biopsies, $1 \mathrm{~mL}$ of blood was taken from the common carotid artery of the same animals through a silicone cannula and was subsequently transferred to identical glass vials. The outlet of the vials was connected to the pump of the spectroscope and headspace gas was pumped into the chamber of the device with a rate of $10 \mathrm{~mL} / \mathrm{min}$.

\section{In vitro and ex vivo studies for the detection of NO generation}

\subsection{Animals}

The experiments were performed on male Sprague-Dawley rats $(n=45 ; 250-300 / 390$ 540 g bw; Animal Research Laboratories, Himberg, Austria/Charles River, Germany) which were kept under controlled standard animal housing conditions. The animals had free access to standard laboratory rodent food and water. They were kept for seven days prior to usage in experiments for accommodation. All interventions were conducted in compliance with the National Institutes of Health's "Guide for the Care and Use of Laboratory Animals" with approval from the Animal Protocol Review Board of the city government of Vienna, Austria. All chemicals were obtained from Sigma-Aldrich (Vienna, Austria), unless otherwise stated.

\subsection{LPS treatment and study design}

LPS from Escherichia coli serotype 026:B6 (activity $\geq 500,000 \mathrm{EU} / \mathrm{mg}$ ) was used for the dose dependence experiments. Six groups of rats were injected with various doses $(0.2,1.3$, 
2.5, 4.7, 6.3, and $8.5 \mathrm{mg} / \mathrm{kg}$ body weight) of LPS dissolved in saline (Fresenius Kabi, Bad Homburg vor der Höhe, Germany). Control animals were injected with saline only. Samples were then collected $16 \mathrm{~h}$ after the LPS injection. In a separate set of experiments, animals were divided into five groups. All rats were injected with the same dose of LPS (Escherichia coli serotype $026: \mathrm{B} 6,8 \mathrm{mg} / \mathrm{kg}$ body weight, activity $\geq 10,000 \mathrm{EU} / \mathrm{mg}$ ) dissolved in saline, and samples were taken 2, 4, 8, and $16 \mathrm{~h}$ after LPS treatment. Control animals were injected with saline only. The LPS solution was vortexed for $1 \mathrm{~min}$ and sonicated for $30 \mathrm{~s}$ before application, and subsequently injected in the penis vein under isoflurane anesthesia in a volume ranging from 0.5 to $0.75 \mathrm{~mL}$.

\subsection{EPR spectroscopy}

EPR spectra were recorded at liquid nitrogen temperature $\left(-196^{\circ} \mathrm{C}\right)$ with a Magnettech MiniScope MS 200 EPR spectrometer (Magnettech, Berlin, Germany) in a quartz finger-type Dewar flask filled with liquid nitrogen. The EPR spectra were then recorded at short- and long-scale ranges. The general settings for a short range were as follows: modulation frequency, $100 \mathrm{kHz}$; microwave frequency, $9.425 \mathrm{GHz}$; microwave power, $8.3 \mathrm{~mW}$; modulation amplitude, $5 \mathrm{G}$; and gain, 200. NO-Hb complexes were recorded at $3300 \pm 200 \mathrm{G}$. The general settings for the long range care were as follows: modulation frequency, $100 \mathrm{kHz}$; microwave frequency, $9.429 \mathrm{GHz}$; microwave power, $30 \mathrm{~mW}$; and modulation amplitude, 6 G. Liver spectra were recorded at $3200 \pm 500$ G. The spectra were quantified by the determination of magnitudes of different components of spectra and by double integration of EPR spectra.

\subsection{NO trapping}

Iron-bound $\mathrm{NO}$ in the intestinal tissue of rats with $\mathrm{CH}_{4}$ treatment was measured using the method described earlier (Kozlov et al., 2001b). Stated briefly, rats were injected subcutaneously with sodium diethyldithiocarbamate (Na-DETC; $500 \mathrm{mg} / \mathrm{kg}$ ) and $\mathrm{FeSO}_{4}(50$ $\mathrm{mg} / \mathrm{kg}$, dissolved in $0.18 \mathrm{mM}$ sodium citrate) separately with 5 minutes between the injections, 20 minutes before SMA occlusion. DETC forms a water-insoluble DETC-Fe complex with iron in the tissue compartment, which is able to bind and stabilize NO as a DETC-Fe-NO complex, and this permits the measurement of NO in the natural compartment where it was formed. 


\section{An in vitro microrheological study}

\subsection{Study design, induction of oxidative stress and $\mathrm{CH}_{4}$ treatment}

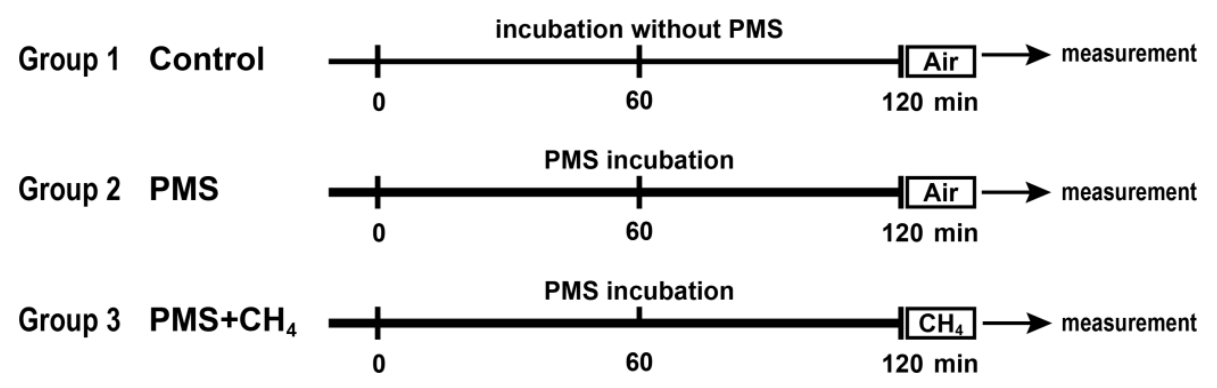

Figure 2. Experimental protocol of the microhemorheological study

Venous blood from healthy male volunteers was collected in lithium heparin coated tubes. Blood samples were placed into three groups, and incubated for 120 minutes at $37^{\circ} \mathrm{C}$ on a rollerbed before RBC aggregation and deformability measurements. A non-treated sample served as the negative control. Oxidative stress was induced with the addition of phenazine methosulfate (PMS, dissolved in phosphate buffered saline, final concentration 200 $\mu \mathrm{M}$ ) and an incubation for 120 minutes (Rabai et al., 2010). Before the study, a dose-response experiment was performed with PMS concentrations between 0 and $400 \mu \mathrm{M}$, to determine the effective concentration. In the third, $\mathrm{CH}_{4}$-treated group, the headspace of the sample was continuously perfused with a gas mixture containing $2.2 \% \mathrm{CH}_{4}$ in normoxic air (Messer Hungarogáz, Budapest, Hungary) for 10 minutes after at the end of the PMS incubation protocol.

RBC deformability and the aggregation of samples were determined by means of ektacytometry and light-transmission aggregometry immediately after the incubation period. Samples were taken from the same vials for both measurements.

\subsection{RBC deformability}

RBC deformability in response to shear forces was determined via a LORCA ektacytometer (Laser-assisted Optical Rotational Cell Analyzer; R\&R Mechatronics, Hoorn, Netherlands).

Immediately after the treatment protocol, $20 \mu \mathrm{L}$ of blood was suspended in $4 \mathrm{~mL}$ of a polyvinylpyrrolidon solution, with a viscosity of $29.8 \mathrm{mPas}$, and injected into the cylinder of the ektacytometer. During the measurement, the temperature was kept at $37^{\circ} \mathrm{C}$.

Deformation is characterized by the elongation index (EI) calculated from the diffraction pattern of laser light on elongated RBCs. The light was captured and analyzed by a video camera and a computer system that calculated an EI as the (length - width) / (length + width) 
of the pattern for 9 different shear stress values ranging from $0.5 \mathrm{~Pa}$ to $50 \mathrm{~Pa}$ (Hardeman et al., 1994).

\subsection{RBC aggregation}

The aggregation characteristics of erythrocytes were assessed by using a light transmission method described earlier (Kiesewetter et al., 1982). Immediately after the treatment protocol, $30 \mu \mathrm{L}$ of blood was transferred to a Myrenne MA-1 Aggregometer (Myrenne GmbH, Roetgen, Germany).

The blood sample was first sheared at $600 \mathrm{~s}^{-1}$ to disperse all pre-existing aggregates, and then the shear rate decreased rapidly to low shear rates. The degree of aggregation was characterized by the aggregation index, which is calculated using the surface area below the light intensity curve in a 10 second period. Measurements were then performed at ambient room temperature.

\section{In vitro analysis of anoxic NO release}

\subsection{Sample preparation}

Male Sprague-Dawley rats (350-450 g) were euthanized by decapitation under isoflurane anesthesia. The liver was excised and placed in ice-cold Ringer solution (B. Braun Melsungen $\mathrm{AG}$, Germany), cut into small pieces, snap-frozen in liquid nitrogen and stored at $-80^{\circ} \mathrm{C}$ until assay. After thawing, the tissue was weighted and supplemented in a 1:10 ratio with an incubation buffer containing $106 \mathrm{mM} \mathrm{KCl}, 5 \mathrm{mM} \mathrm{KH} \mathrm{PO}_{4}, 20 \mathrm{mM}$ Tris- $\mathrm{HCl}$ and $0.5 \mathrm{mM}$ EDTA. The $\mathrm{pH}$ of the solution was set to 6.0 to mimic ischemic tissue with severe acidosis. Afterwards, the liver sample was homogenized with an overhead stirrer (RW16, IKA Werke, Germany).

\subsection{NO measurement protocol}

NO release from liver homogenate was measured on-line by means of chemiluminescence (Sievers 280i, General Electric, USA) under anoxic conditions, $\mathrm{pH} 6.0$ and $37^{\circ} \mathrm{C} .0 .5 \mathrm{~mL}$ of diluted liver homogenate supplemented with $19 \mathrm{~mL}$ of incubation buffer and $38 \mu \mathrm{L}$ antifoam was added into the glass chamber of the device. Then the samples were equilibrated with nitrogen or nitrogen containing 2.2\% $\mathrm{CH}_{4}$ (Messer Hungarogáz, Budapest, Hungary) under continuous gas flow for 10 minutes. Afterwards, $4.4 \mathrm{mM} \mathrm{NaNO}_{2}$ was added and the $\mathrm{NO}$ released from the homogenate was measured in real-time for a 15 minute period.

\section{Statistical analysis}

For a statistical evaluation of the data, GraphPad Prism 5.01 for Windows (GraphPad Software, La Jolla, California, USA) was used. The statistical analysis was performed by a two-way analysis of variance of repeated measures followed by Bonferroni post-hoc test in 
normally distributed data and Kruskal-Wallis one-way analysis of variance on ranks combined with Dunn's method for pairwise multiple comparisons in groups showing a nonGaussian distribution. Pearson's test was used to assess the statistical significance $(p<0.0001)$ of correlations. Taking into account the fact that parts of the in vivo data were not normally distributed (not Gaussian), we displayed the data as box plots, where possible. Median values and $75^{\text {th }}$ and $25^{\text {th }}$ percentiles are given and in each case, $\mathrm{p}$ values $<0.05$ were considered significant. 


\section{Results}

\section{The kinetics of $\mathrm{CH}_{4}$ transport}

The $\mathrm{CH}_{4}$ concentration in the baseline samples of non- $\mathrm{CH}_{4}$-producer animals remained below the background levels in the arterial blood and in the ileum tissue prior to the beginning of the experiment (figures $3 \mathrm{~A}$ and $3 \mathrm{~B}$, "Baseline"). After 5 minutes of normoxic $\mathrm{CH}_{4}$ inhalation with a flow rate of $300 \mathrm{~mL} / \mathrm{min}$, at the end of the SMA ischemia substantially increased $\mathrm{CH}_{4}$ concentrations were detected in the systemic arterial blood and there was a slight increase in the ileum as well (figures $3 \mathrm{~A}$ and $3 \mathrm{~B}$, "Isch 45 ' $-\mathrm{CH}_{4} 5$ "'). 10 minutes into the reperfusion phase, at the end of the 15 min inhalation of normoxic $\mathrm{CH}_{4}$-air mixture, $\mathrm{CH}_{4}$ concentration in the ileal tissue also increased (Figure 3B, "Rep 10' $-\mathrm{CH}_{4} 15$ '”). In samples taken at the $60^{\text {th }}$ minute of the reperfusion, 50 minutes after the end of $\mathrm{CH}_{4}$ treatment, no significant amounts of $\mathrm{CH}_{4}$ were found in intestinal or blood samples (figures $3 \mathrm{~A}$ and $3 \mathrm{~B}$, “Rep 60””).

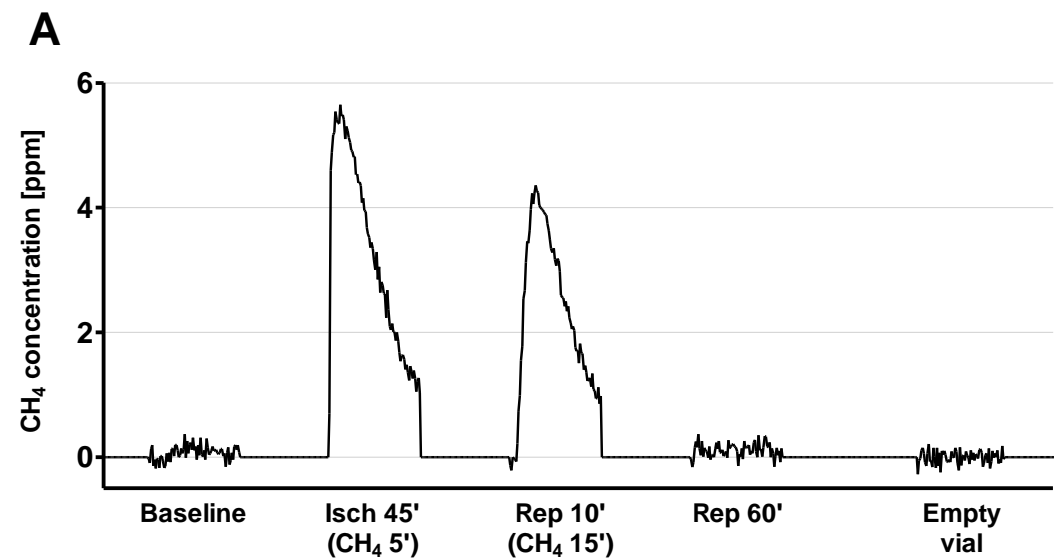

B

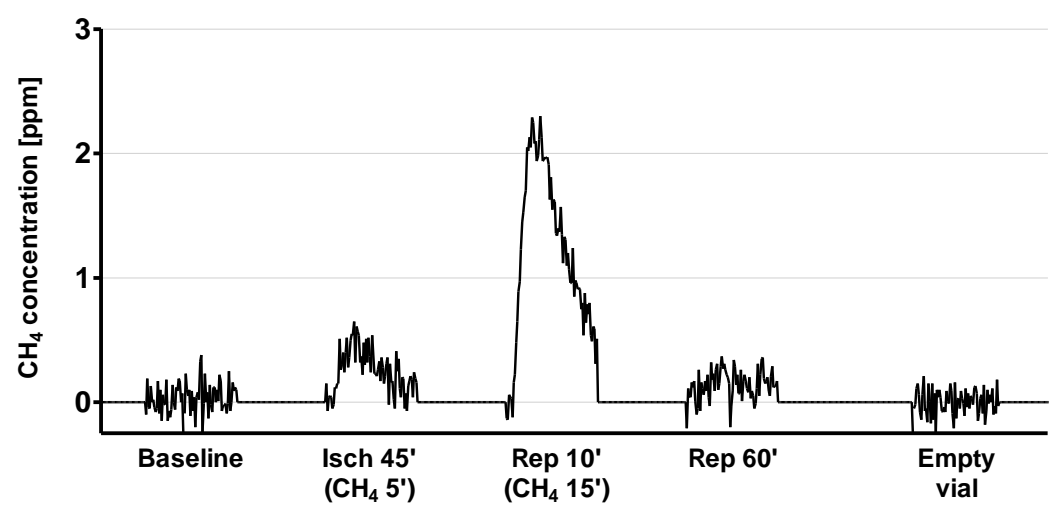

Figure 3. $\mathrm{CH}_{4}$ transport to the intestine. $\mathrm{CH}_{4}$ concentrations in blood (A) and ileum (B) samples taken during the $\mathrm{CH}_{4}$-air inhalation protocol in a pilot study. An original recording of photoacoustic signals as a function of time. At the indicated time point during the experiments, a tissue sample of the ileum, weighing approximately $200 \mathrm{mg}$ was taken and placed immediately in a glass vial. Simultaneously, blood samples $(1 \mathrm{~mL}$ each) were taken from the common carotid artery into glass vials. Gas samples from the headspace $(20 \mathrm{~mL})$ were thereafter transferred to the photoacoustic 
detection system and each tissue specimen was measured for 10 minutes. Values are expressed as parts-per-million (ppm) and are corrected for background $\mathrm{CH}_{4}$ levels. Baseline - prior to $\mathrm{CH}_{4}$ inhalation and ischemia. Isch $45^{\prime}\left(\mathrm{CH}_{4} 5^{\prime}\right)$ - end of mesenteric ischemia, 5 minutes of normoxic $\mathrm{CH}_{4}$ inhalation. Rep 10' $\left(\mathrm{CH}_{4} 15^{\prime}\right)-10^{\text {th }}$ minute of reperfusion, end of the 15-min normoxic $\mathrm{CH}_{4}$ inhalation. Rep $60^{\prime}-60^{\text {th }}$ minute of reperfusion. Empty vial $-\mathrm{CH}_{4}$ concentration without biological sample, used for background-correction.

\section{The small intestinal permeability}

\section{Small intestinal epithelial barrier function}

The epithelial permeability (EP) index was determined to assess the barrier function of the intestinal mucosa during the re-establishment of the blood flow to the previously ischemic tissues (Figure 4A). The EP did not change in sham-operated, control animals, while the plasma levels of FD4 rose steeply in the IR group, which indicates a rapid loss of the epithelial barrier function. Normoxic $\mathrm{CH}_{4}$ treatment resulted in significantly lower EP levels, implying there were preserved interepithelial junctions.

Later in the reperfusion (Figure 4B, below), the EP index in non-treated animals decreased, suggesting an improved barrier function as compared to that in the early phase; while in the $\mathrm{CH}_{4}$-treated group, the change was similar to those observed in the early phase of reperfusion.

The EP index remained at the baseline level in the control animals.
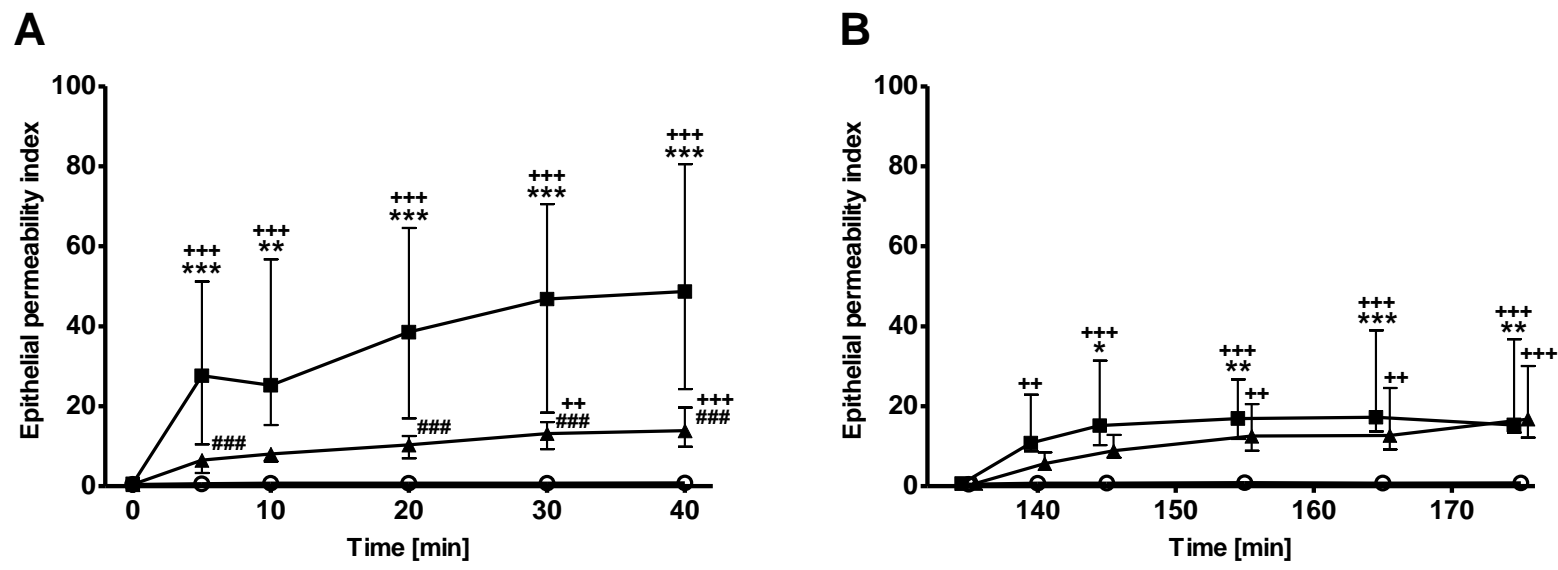

Figure 4. Epithelial permeability. Changes in epithelial permeability (EP) in the sham-operated (empty circles), mesenteric IR (black squares), and $\mathrm{CH}_{4}$-treated IR (black triangles) groups during early (A) and late phases (B) of reperfusion. The EP was assessed in each period and the permeability index was calculated as described earlier (see the Methods section for a description of the experiments). The data are expressed as median, $25^{\text {th }}$ and $75^{\text {th }}$ percentiles. Here, $* *$ means $p<0.01$ between groups vs. sham-operated group; \#\#\# means $\mathrm{p}<0.001$ between $\mathrm{CH}_{4}$-treated and IR groups, while ++ means $p<0.01$ and +++ means $p<0.001$ compared to baseline values within groups. 


\section{Small intestinal microvascular barrier function}

The vascular permeability (VP) assessed by Evans blue extravasation increased in the early reperfusion relative to sham-operated control animals, but statistically significant differences between the experimental groups were not detected either in the early (Figure 5A) or the later (Figure 5B) phases of reperfusion.
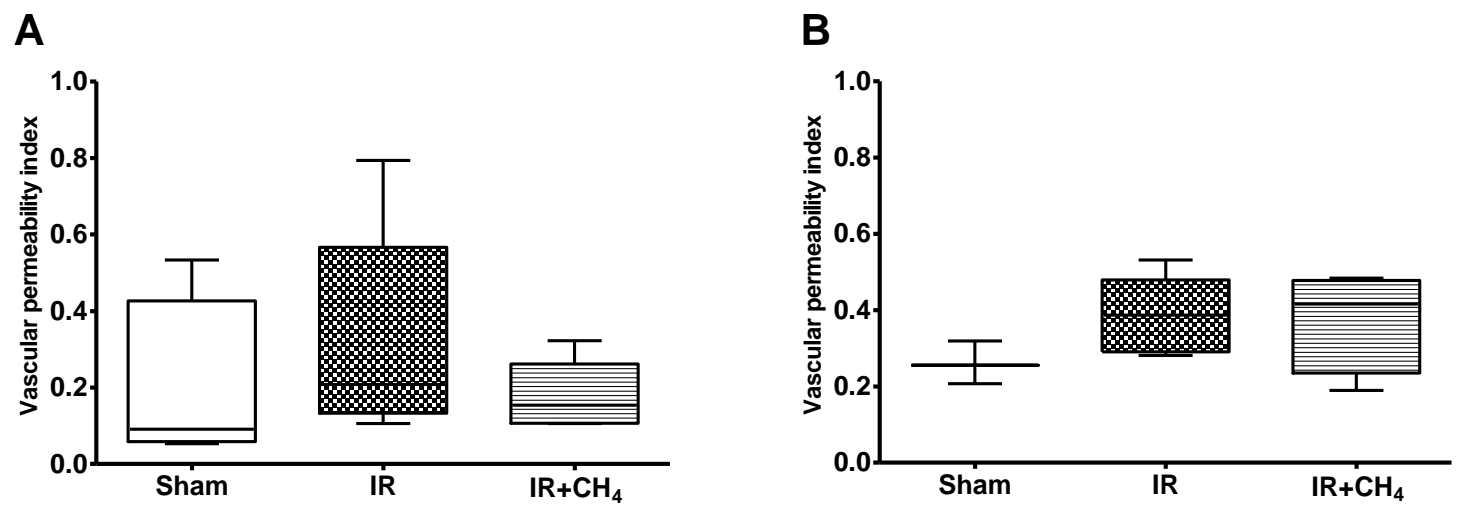

Figure 5. Vascular permeability. Changes in vascular permeability (VP) in the sham-operated (Sham, empty boxes), mesenteric IR (IR, checkered boxes), and $\mathrm{CH}_{4}$-treated IR (IR+ $\mathrm{CH}_{4}$, hatched boxes) groups during early (A) and late phases (B) of reperfusion. The VP index was calculated using a spectrophotometric evaluation of Evans Blue extravasation (see Materials and methods). The results are expressed as median, $25^{\text {th }}$ and $75^{\text {th }}$ percentiles.

\section{Micro- and macrocirculatory changes}

Prior to the induction of SMA occlusion, the RBC velocity in the microvessels of the ileal serosa was similar in all groups (see Figure 6). In the $15^{\text {th }}$ min of reperfusion, the intestinal microcirculation of the IR group was significantly impaired. In the $\mathrm{IR}+\mathrm{CH}_{4}$-treated groups the RBC velocity did not differ from the sham-operated groups, implying improved microcirculation. By the 120 min of the reperfusion, no differences could be seen among the groups.

The SMA blood flow was assessed continuously during the experiments (Figure 7). In the IR and $\mathrm{IR}+\mathrm{CH}_{4}$ groups, the complete cessation of blood flow was followed by different reactions during reperfusion. The SMA flow in IR group remained significantly low as compared to baseline levels; while in $\mathrm{CH}_{4}$-treated animals, the SMA flow was significantly higher compared to that in the IR group. 


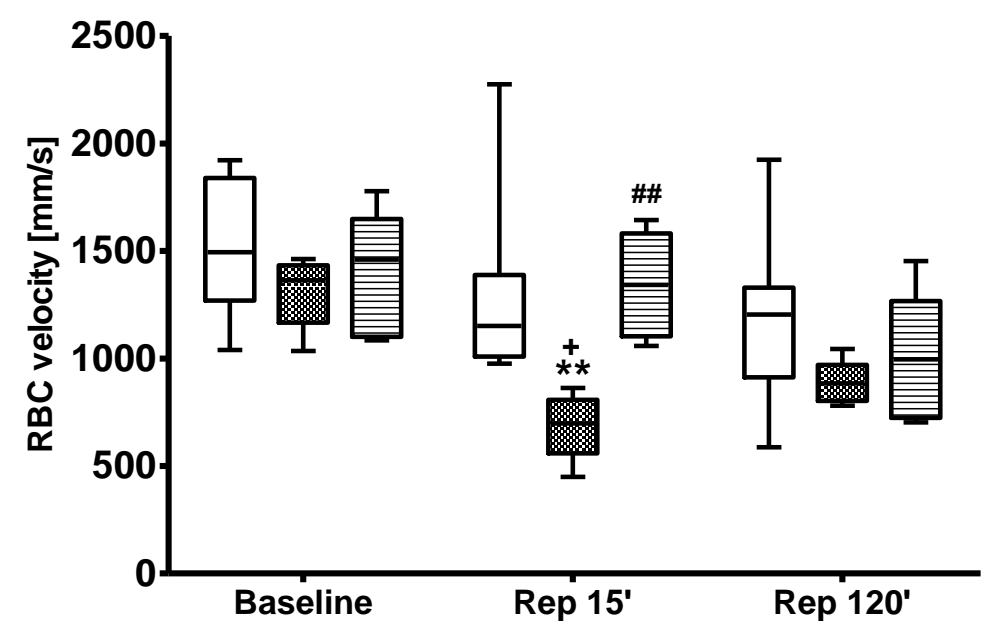

Figure 6. RBC velocity. Changes in red blood cell (RBC) velocity in the microvessels of the serosal surface of the ileum in response to a sham operation (empty boxes) or $45 \mathrm{~min}$ of mesenteric ischemia followed by $120 \mathrm{~min}$ of reperfusion (IR groups, checkered boxes) and in rats treated with a normoxic $\left(21 \% \mathrm{O}_{2}\right)$ gas mixture containing $2.2 \% \mathrm{CH}_{4}$ for $5 \mathrm{~min}$ at the end of the ischemia and for $10 \mathrm{~min}$ at the beginning of the reperfusion period ( $\mathrm{IR}+\mathrm{CH}_{4}$, hatched boxes). Measurements were performed at baseline conditions (Baseline), $15 \mathrm{~min}$ after reperfusion (Rep 15') and $120 \mathrm{~min}$ after reperfusion (Rep $\left.120^{\prime}\right)$. ${ }^{* *}$ means $\mathrm{p}<0.01$ between groups $v s$ sham-operated group, \#\# means $\mathrm{p}<0.01$ between IR $v s$ $\mathrm{IR}+\mathrm{CH}_{4}$ groups, $+\mathrm{p}<0.05$ compared with baseline values within groups.

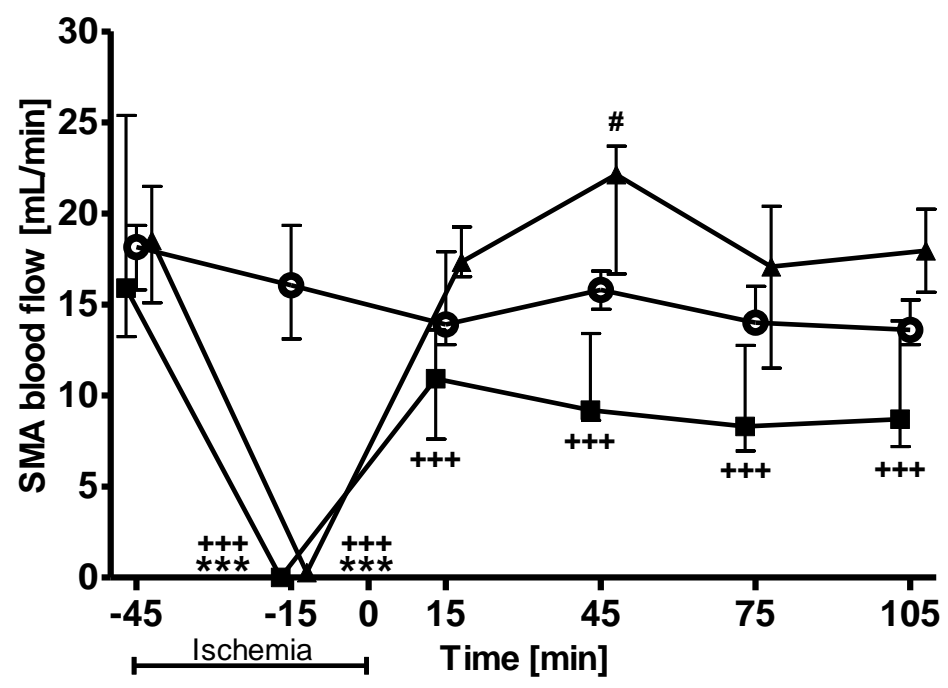

Figure 7. SMA blood flow. Changes in the superior mesenteric artery (SMA) blood flow in the shamoperated (empty circles), mesenteric IR (black squares), and $\mathrm{CH}_{4}$-treated IR (black triangles) groups. 0 min on the $X$ axis denotes the start of reperfusion. Results are expressed as median, $25^{\text {th }}$ and $75^{\text {th }}$ percentiles. Here, $* * *$ means $\mathrm{p}<0.001$ between groups $v s$. sham-operated group; \# indicates $\mathrm{p}<0.05$ between $\mathrm{CH}_{4}$-treated and IR groups, while +++ means $\mathrm{p}<0.001$ compared with baseline values within groups. 
ROS and RNS levels

Tissue NTyr concentration (Figure 8A) is an indicator of protein nitration produced by a chemical reaction associated with ONOO generation. The NTyr levels were elevated by the 180 min of reperfusion in the IR group as compared to those in the sham-operated controls, while the levels did not differ from the controls in the $\mathrm{CH}_{4}$-treated group.

$\mathrm{O}_{2}^{\bullet-}$ levels

A primary cellular ROS, $\mathrm{O}_{2}{ }^{\bullet-}$, was detected in ileal biopsies at the beginning of experiments (Figure 8B), and no between-group differences were observed. At $15 \mathrm{~min}$ after the reestablishment of blood flow, the samples from the IR group contained significantly higher levels of $\mathrm{O}_{2}{ }^{\bullet-}$ than those from the control and $\mathrm{CH}_{4}$-treated animals.
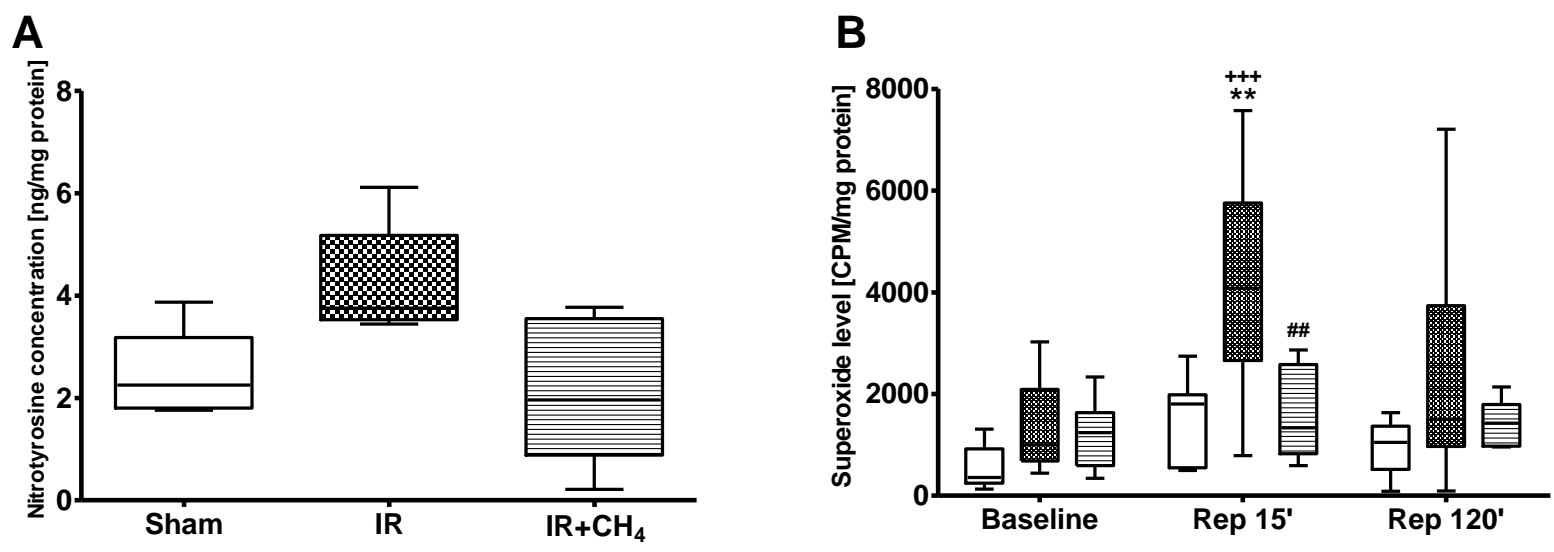

Figure 8. Intestinal nitrotyrosine levels and capacity to generate superoxide radical. Changes in mucosal NTyr (panel A) and $\mathrm{O}_{2}{ }^{--}$(panel B) production in sham-operated control animals (Sham, clear boxes) and after $45 \mathrm{~min}$ of SMA occlusion and $180 \mathrm{~min}$ reperfusion (IR group, checkered boxes). In the methane-treated group ( $\mathrm{IR}+\mathrm{CH}_{4}$, hatched boxes) the animals inhaled a normoxic $\left(21 \% \mathrm{O}_{2}\right)$ gas mixture containing $2.2 \% \mathrm{CH}_{4}$ for 5 minutes in the final phase of the ischemia and for 10 minutes in the initial phase of the reperfusion period (or 15 minutes in total). The NTyr level was measured by means of EIA from samples taken after $180 \mathrm{~min}$ of reperfusion and normalized to the total protein content of the tissue. $\mathrm{O}_{2}{ }^{--}$levels (panel B) were measured by chemiluminescence at the beginning of the experiment (Baseline), $15 \mathrm{~min}$ (Rep 15') and $120 \mathrm{~min}$ after reperfusion (Rep 120'), and they were normalized to the protein content of the tissue sample. Data are expressed as median, $25^{\text {th }}$ and $75^{\text {th }}$ percentiles. Here, ${ }^{* *}$ means $\mathrm{p}<0.01$ compared to the sham-operated group; \#\# means $\mathrm{p}<0.01$ between the $\mathrm{CH}_{4}$-treated group and IR group, while +++ means $\mathrm{p}<0.001$ compared to baseline values within groups. 


\section{Tissue ET-1 levels}

The ET-1 concentration was measured from plasma samples at the end of the 180-min reperfusion period. In the IR group, there was a significant elevation at $180 \mathrm{~min}$ after reperfusion relative to that in control animals. This elevation was significantly reduced in the $\mathrm{IR}+\mathrm{CH}_{4}$-treated group (Figure 9A).

\section{Tissue MPO levels}

The activity of MPO, a marker enzyme of PMN granulocytes, was assessed in intestinal homogenates at the end of the late reperfusion phase. A significant MPO elevation was present in both the IR and the $\mathrm{CH}_{4}$-treated groups, indicating acute inflammation and extravasation of leukocytes into the tissue (Figure 9B).

A

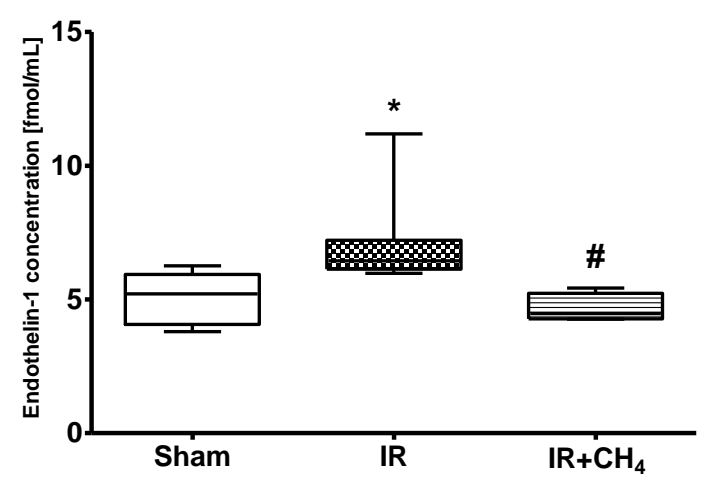

B

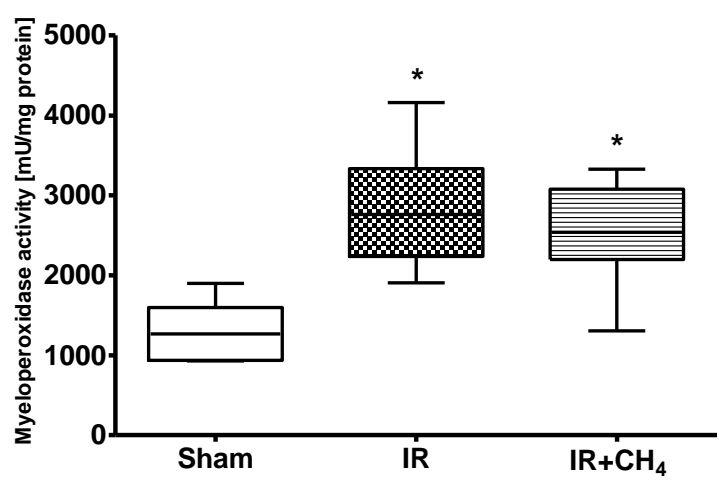

Figure 9. Endothelin-1 and MPO. Changes in tissue myeloperoxidase (MPO) activity and the plasma endothelin-1 (ET-1) concentration at the end of the $180 \mathrm{~min}$ reperfusion in the sham-operated (Sham, clear box), IR (checkered box), and $\mathrm{CH}_{4}$-treated groups ( $\mathrm{IR}+\mathrm{CH}_{4}$, hatched boxes). Here, * means $\mathrm{p}<0.05$ between groups $v s$ sham-operated group, \# means $\mathrm{p}<0.05$ between IR $v s \mathrm{IR}+\mathrm{CH}_{4}$ groups. 


\section{Structural integrity of small intestinal mucosa}

Tissue samples were taken in the early reperfusion phase for conventional histology to provide structural data on the ileum mucosa. In the sham-operated group (Figure 10A), villus morphology was normal, but in the IR group (Figure 10B) extensively damaged, denudated and progressively shrinking villi were typically found in association with increased luminal debris formation. Furthermore, the congestion of RBCs in the microvessels of the villi was seen. $\mathrm{CH}_{4}$ treatment (Figure 10C) preserved the integrity of the mucosal layer with moderate debris formation and slight alterations of the lamina propria.

Intravital CLSEM images were recorded to get information on the structural condition of the surface of the epithelium and the microscopic histology data were evaluated using a semiquantitative scoring system (Figure 11D). Normal villi with intact epithelial cells were observed in the control group (Figure 11A). Relative to the typically continuous, unbroken epithelial lining in the sham-operated animals, the mucosa was severely damaged after a 30 min reperfusion. Epithelial defects stretching across the villi were regularly seen (Figure 11B). No epithelial disruptions on the lumen surface were present in the $\mathrm{CH}_{4}$-treated group (Figure 11C) and the microstructural damage (pathological changes?) reflected in the injury score was significantly lower than that observed in non-treated IR animals.
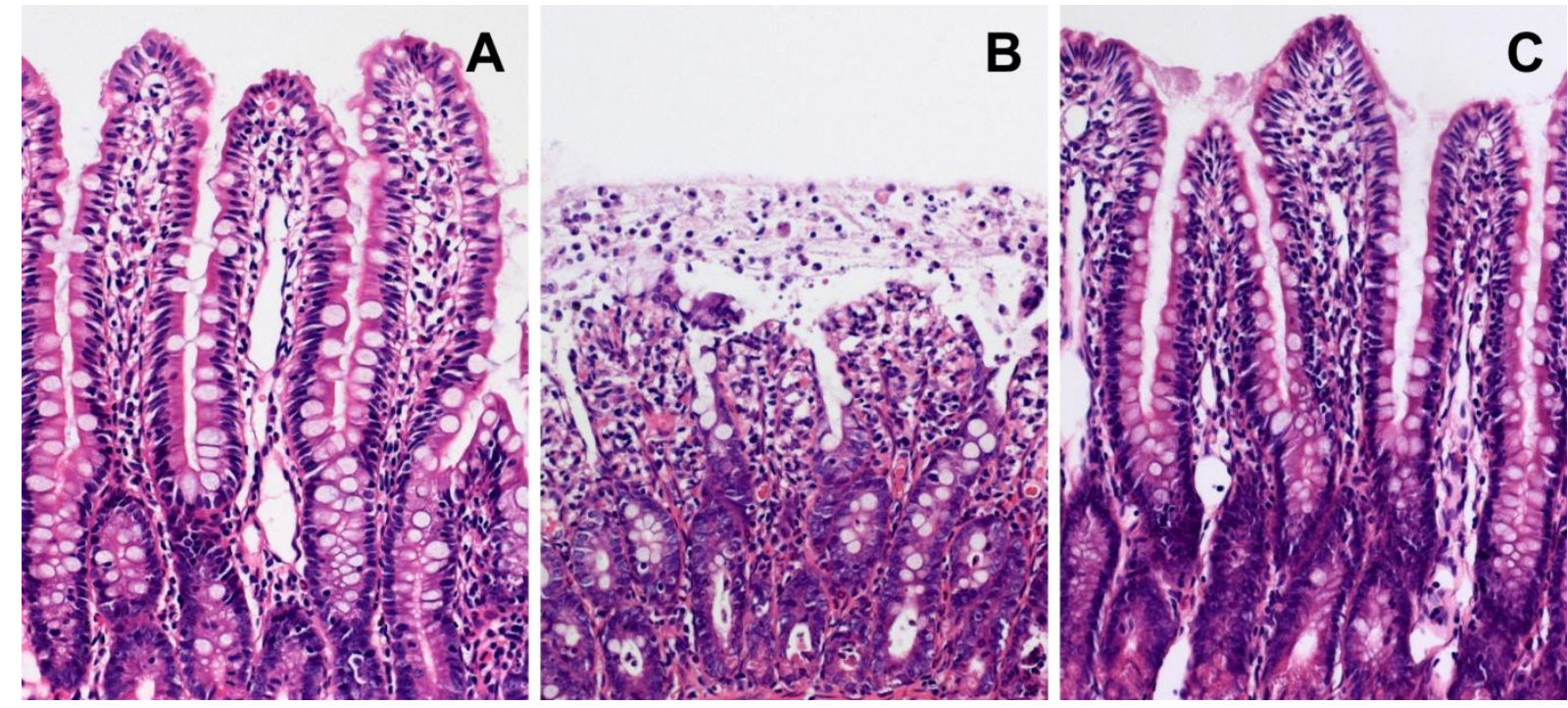

Figure 10. Conventional histology. Representative photomicrographs of the ileum mucosa 30 minutes after the end of the ischemia in sham operated animals (A), ischemia-reperfusion (B) and ischemia-reperfusion and $\mathrm{CH}_{4}$ treated group $(\mathbf{C})$. The images were taken with a 40x objective after hematoxilin-eosin staining. 

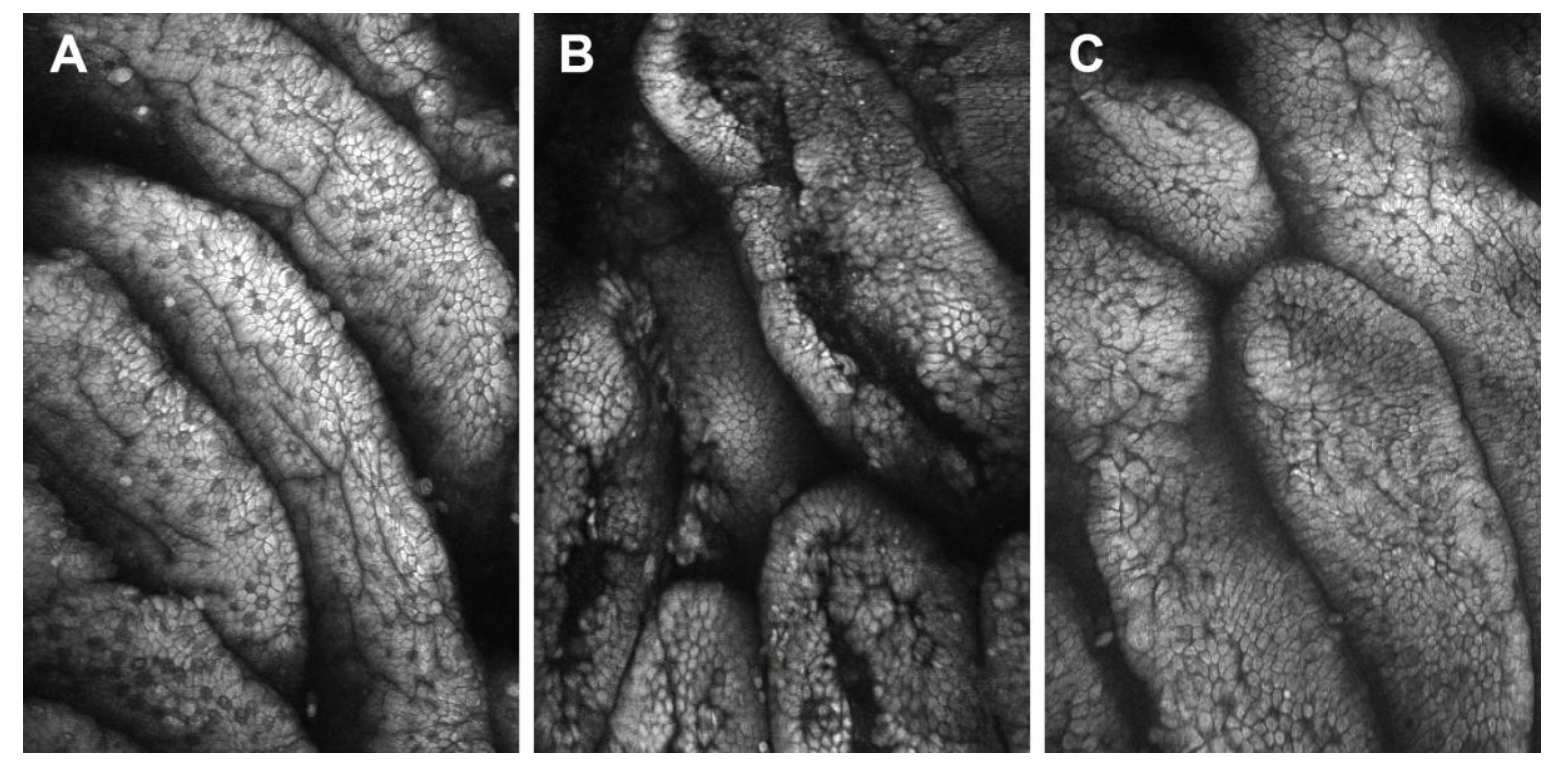

D

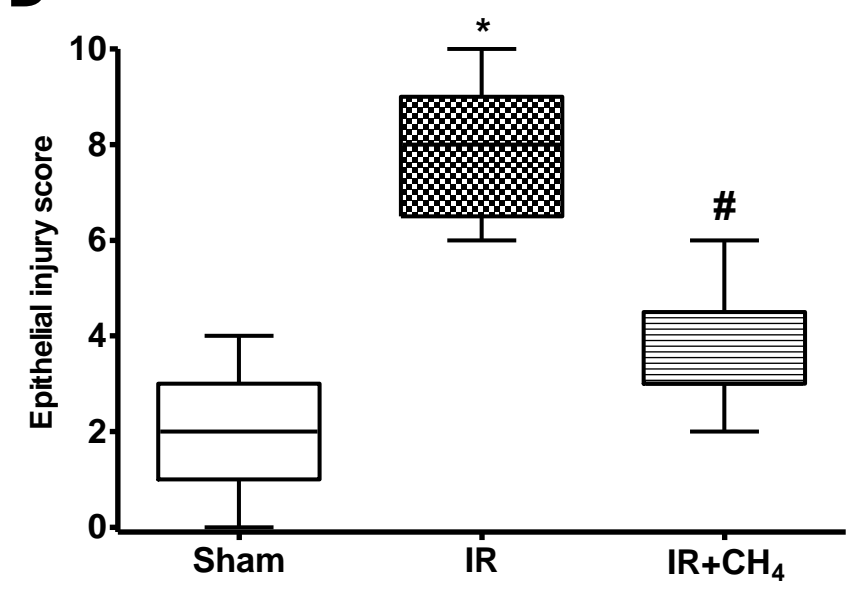

Figure 11. Confocal laser scanning endomicroscopic images of the intestinal epithelium. Top panel In vivo histology images recorded by confocal laser scanning endomicroscopy (CLSEM) after the topical administration of sodium acriflavine: A: Sham-operated group, B: IR group, $45 \mathrm{~min}$ of SMA occlusion and 30 min reperfusion, $\mathbf{C}$ : $\mathrm{IR}+\mathrm{CH}_{4}$ treated group, $45 \mathrm{~min}$ of SMA ischemia and 30 min reperfusion. Bottom panel Grading of in vivo histology on a semiquantitative scoring system. The plots show the median and the $25^{\text {th }}$ and $75^{\text {th }}$ percentiles. Here, ${ }^{*}$ means $\mathrm{p}<0.05$ between groups $v s$. shamoperated group, \# means $\mathrm{p}<0.05$ between IR $v s \mathrm{IR}+\mathrm{CH}_{4}$ groups.

\section{The detection of NO by EPR without exogenously added spin-trapping molecules}

EPR spectroscopy was applied to validate measurements of NO levels using endogenous trapping molecules. $16 \mathrm{~h}$ after an LPS injection, there was a dose-dependent increase at $\mathrm{g}=$ 2.075 and $g=2.042$ in the complex EPR signal of liver, corresponding to hemoglobin-bound $\mathrm{NO}(\mathrm{NO}-\mathrm{Hb})$ and Fe-bound $\mathrm{NO}(\mathrm{NO}-\mathrm{Fe}$; Figure 12B). In blood samples taken from the same animals, only NO-Hb signals at $\mathrm{g}=2.075$ were present (Figure 12A). There was a 
good correlation of increasing LPS doses with $\mathrm{NO}-\mathrm{Hb}$ and $\mathrm{NO}-\mathrm{Fe}$ signals (Figure 12C-E), which had been calibrated previously (data not shown). The correlation was strong between $\mathrm{NO}-\mathrm{Hb}$ and $\mathrm{NO}-\mathrm{Fe}$ signals as well (Figure 12F-H).

a

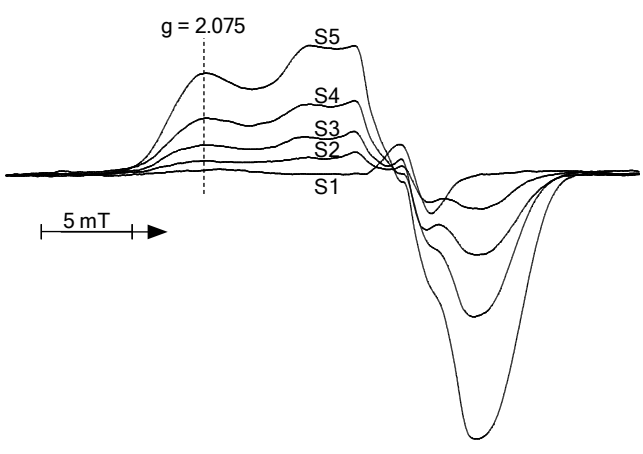

C

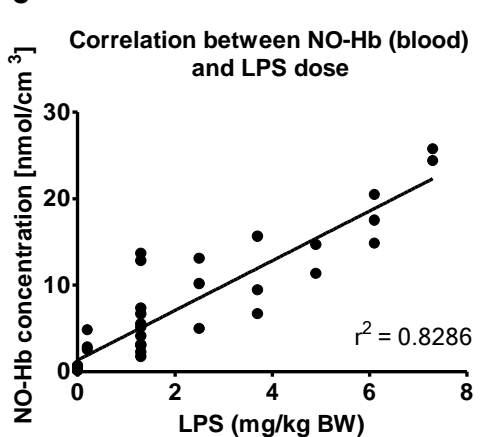

f

Correlation between NO-Hb in blood and in liver tissue

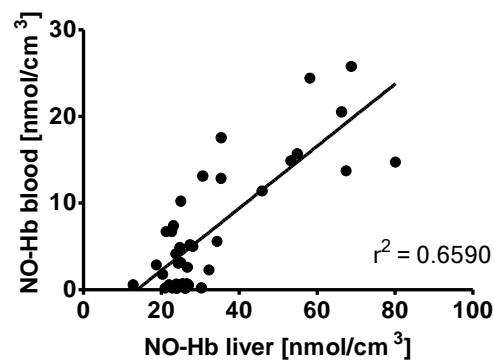

b

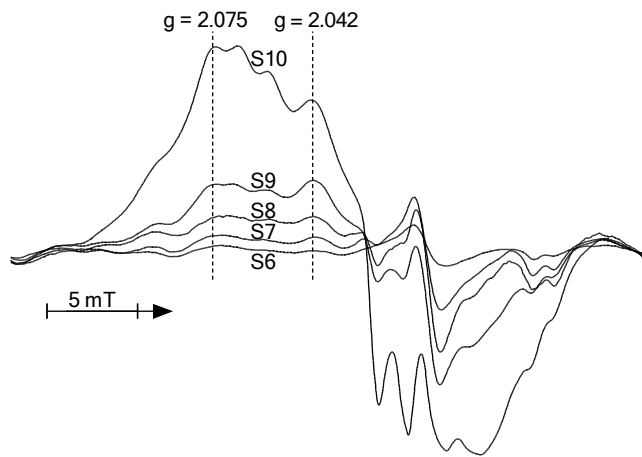

\section{d}

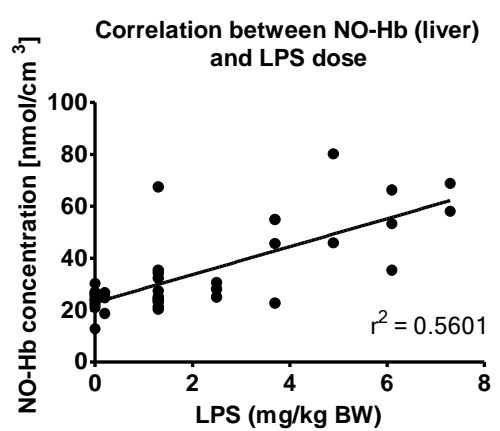

g

Correlation between NO-Fe (liver) and NO-Hb (blood)

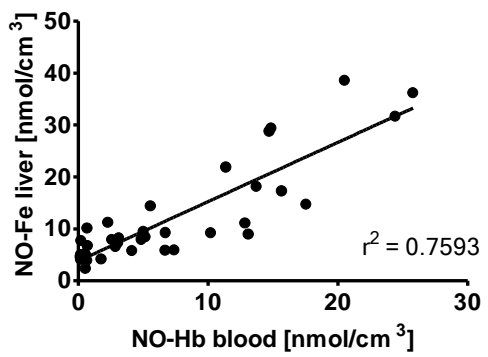

e

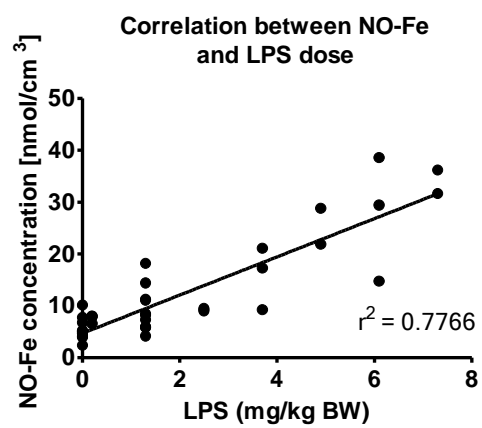

h

Correlation between NO-Fe (liver) and NO-Hb (liver)

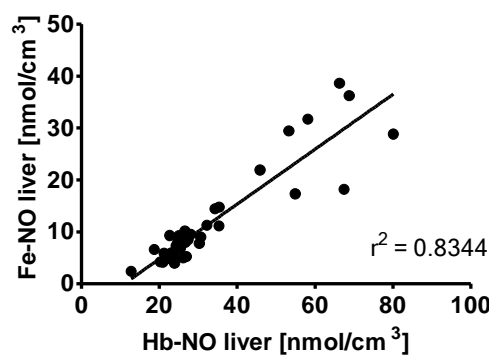

Figure 12. Quantification of NO formed in cells and in blood upon LPS treatment and the characterization of NO pools. The dose of LPS varied from 0.2 to $7.3 \mathrm{mg} / \mathrm{kg}$ body weight. Blood (A) and liver (B) EPR spectra were recorded $16 \mathrm{~h}$ after an injection of 0.2 (S2, S7), 3.7 (S3, S8), 4.9 (S4, $\mathrm{S} 9$ ), and 8.5 (S5, S10) $\mathrm{mg} / \mathrm{kg}$ body weight LPS or an equivalent volume of $\mathrm{NaCl}$ (S1, S6). NO- $\mathrm{Hb}$ in blood (C) and liver (D), and NO-Fe in liver tissue (E) as a function of LPS dose. The correlation between $\mathrm{NO}-\mathrm{Hb}$ in blood and liver (F), NO-Fe in liver and $\mathrm{NO}-\mathrm{Hb}$ in blood (G) and $\mathrm{NO}-\mathrm{Fe}$ and $\mathrm{NO}-$ $\mathrm{Hb}$ in liver $(\mathrm{H})$. Abbreviations: $\mathrm{m}$, slope; $r$, coefficient of determination; $\mathrm{S}$, signal 


\section{The effects of $\mathrm{CH}_{4}$ on NO release under ischemia}

Using Na-DETC and exogenously added iron to form stable, intracellular NO-Fe-DETC complexes for EPR analysis, we measured NO levels in the duodenum and ileum of rats (see

Figure 13). There was a trend showing increased NO concentrations at the end of a 45-min ischemia in both parts of the intestine as compared to those in sham-operated animals. The inhalation of a normoxic gas mixture containing $2.2 \% \mathrm{CH}_{4}$ for 10 min resulted in lower levels of NO. During the reperfusion phase, we did not see any similar trends (data not shown).
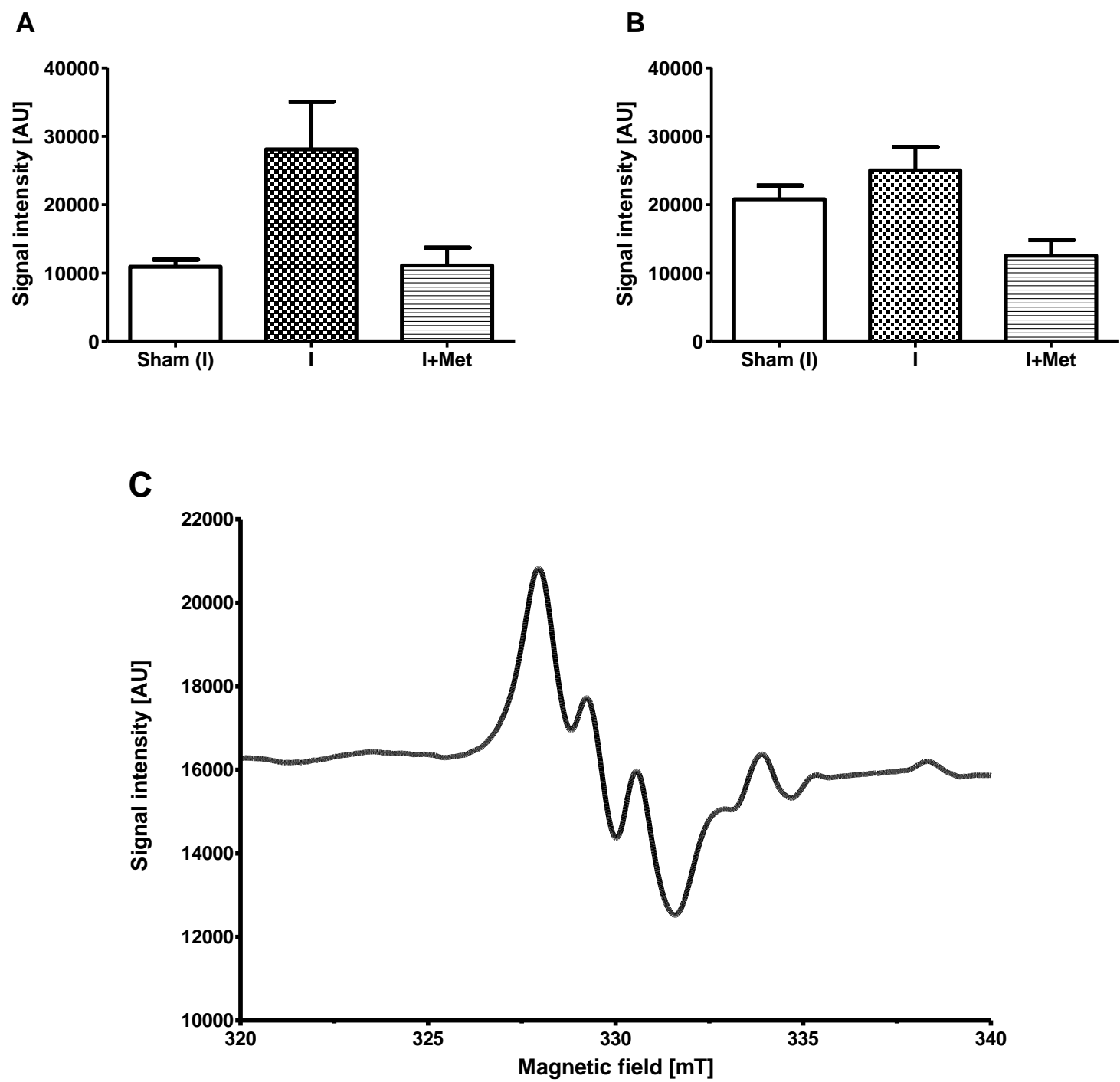

Figure 13. NO-Fe-DETC levels in samples taken from the duodenum (panel A) and ileum (panel B) of rats during mesenteric IR with or without $\mathrm{CH}_{4}$ treatments. Control animals (Sham, empty bars), animals after 45 min of SMA occlusion without reperfusion (I group, checkered bars). In the $\mathrm{CH}_{4}$ treated group $\left(\mathrm{I}+\mathrm{CH}_{4}\right.$, hatched bars), the animals inhaled a normoxic $\left(21 \% \mathrm{O}_{2}\right)$ gas mixture containing $2.2 \% \mathrm{CH}_{4}$ for $10 \mathrm{~min}$ in the final phase of ischemia. Here, data are expressed as the mean $\pm \mathrm{SD}(\mathrm{n}=3$ each). Panel C: characteristic EPR signal of NO-Fe-DETC. 
To estimate whether or not $\mathrm{CH}_{4}$ can modulate $\mathrm{NO}$ release from $\mathrm{NO}_{2}{ }^{-}$in anoxic tissues, liver homogenate was incubated with pure $\mathrm{N}_{2}$ or $\mathrm{N}_{2}$ supplemented with $2.2 \% \mathrm{CH}_{4}$. NO production was alleviated in the presence of $\mathrm{CH}_{4}$; reaching significantly lower levels as compared to those for the $\mathrm{N}_{2}$ only group from the $10^{\text {th }}$ min after adding $\mathrm{NaNO}_{2}$ (Figure 14).

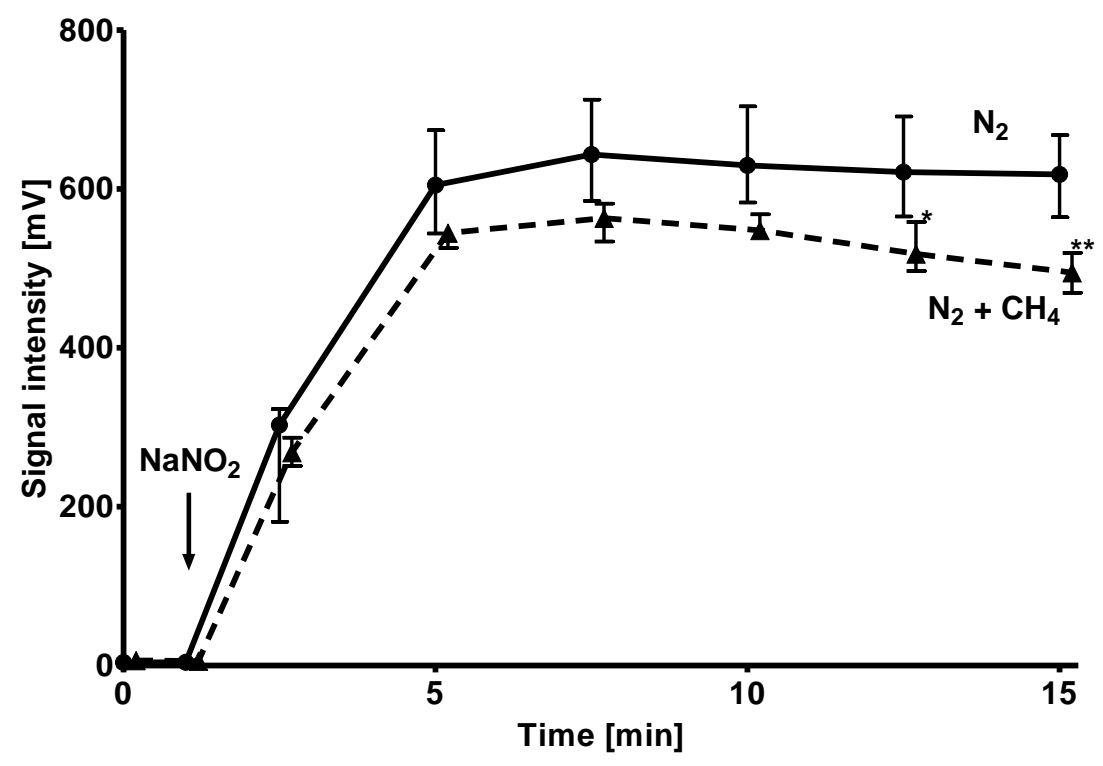

Figure 14. The NO generation of liver homogenate under anoxia. After equilibration with $\mathrm{N}_{2}$ or $\mathrm{N}_{2}$ containing $2.2 \% \mathrm{CH}_{4}, 4.4 \mathrm{mM} \mathrm{NaNO}_{2}$ was added (arrow). NO release was detected in real-time and it is plotted against the time elapsed. The signal intensity is proportional to the NO generated. Median values and the range are given. * means $\mathrm{p}<0.05$ and $* *$ means $\mathrm{p}<0.01 \mathrm{~N}_{2}+\mathrm{CH}_{4} v s \mathrm{~N}_{2}$ group ( $\mathrm{n}=3$ each). 


\section{The effects of $\mathrm{CH}_{4}$ on the microhemorheological parameters of whole blood}

The deformability of erythrocytes taken from human blood was measured using a laserassisted optical rotational method (Figure 15). Oxidative stress, induced by in vitro treatment with the oxidizer PMS, resulted in a significantly decreased elongation index from low to moderately high shear stress rates, as compared to that for the non-treated control samples. Normoxic $\mathrm{CH}_{4}$ incubation, applied after the oxidizer incubation, was able to partly counteract the decreased rigidity of RBCs at moderate levels of shear stress (Figure 15B-D).
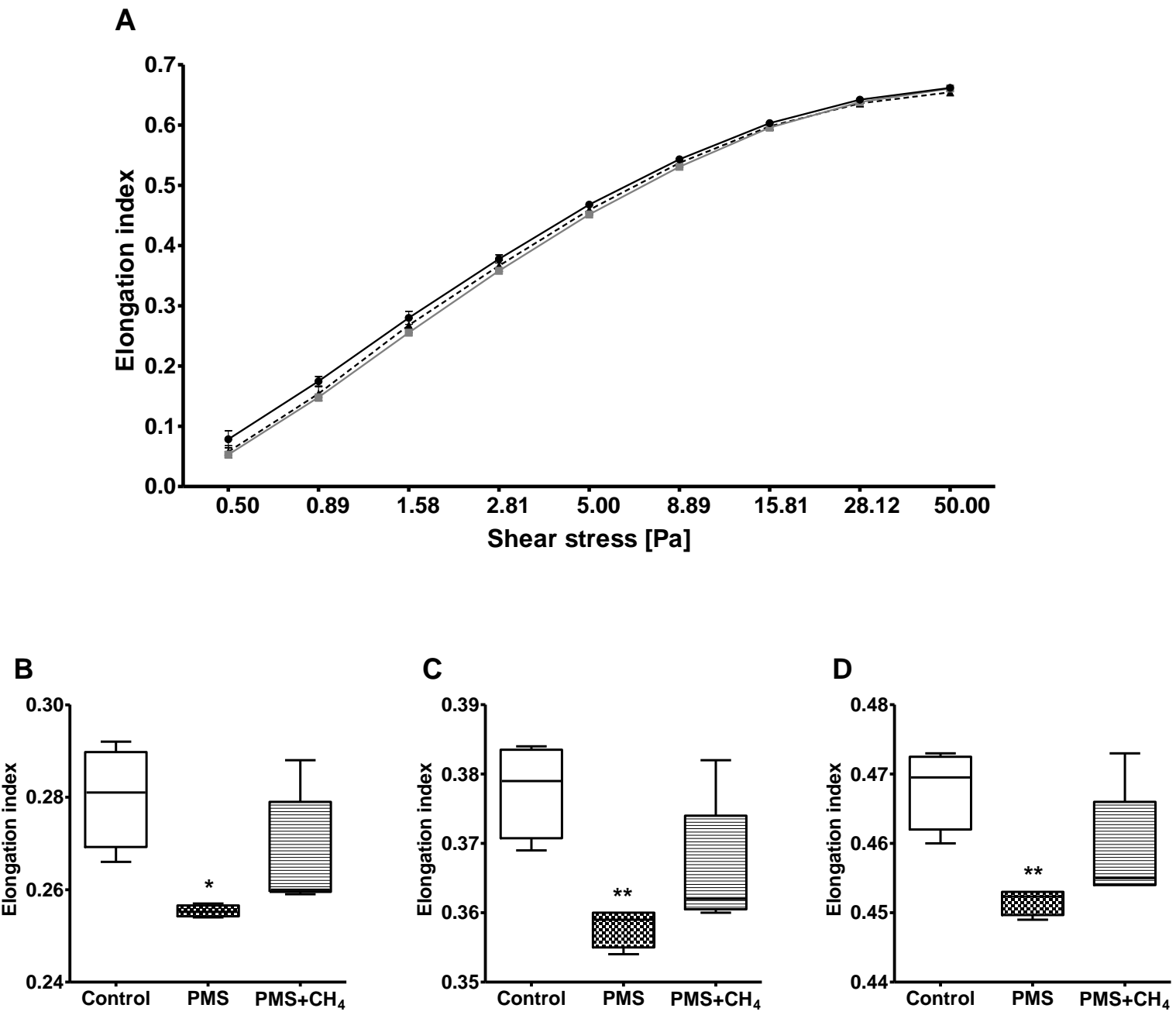

Figure 15. RBC deformability. Deformability changes of RBCs in vitro under increasing shear stress rates (panel A) and values at $1.57 \mathrm{~Pa}(\mathrm{~B}), 2.81 \mathrm{~Pa}(\mathrm{C})$ and $5.00 \mathrm{~Pa}(\mathrm{D})$ depicted as box plots. The higher elongation indices represent more elongated, hence more oval erythrocytes. Control samples (black line and empty boxes), samples incubated with PMS for 2 hours to induce oxidative stress (PMS groups, grey line and checkered boxes) and blood samples treated with a normoxic $\left(21 \% \mathrm{O}_{2}\right)$ gas mixture containing $2.2 \% \mathrm{CH}_{4}$ for $10 \mathrm{~min}$ after $2 \mathrm{~h}$ of PMS challenge $\left(\mathrm{PMS}+\mathrm{CH}_{4}\right.$, dashed line and hatched boxes). On the shear-stress curve means $\pm \mathrm{SD}$ are given, while the box plots show the median and the $25^{\text {th }}$ and $75^{\text {th }}$ percentiles. Here, $*$ means $\mathrm{p}<0.05$ and $* *$ means $\mathrm{p}<0.01$ PMS $v s$ sham-operated group and $n=4-5$. 
Oxidative stress in vitro increased the aggregation of erythrocytes at low shear-stress as compared to that in control samples (Figure 16). After applying $\mathrm{CH}_{4}$, these values significantly decreased to the level of non-treated control samples.

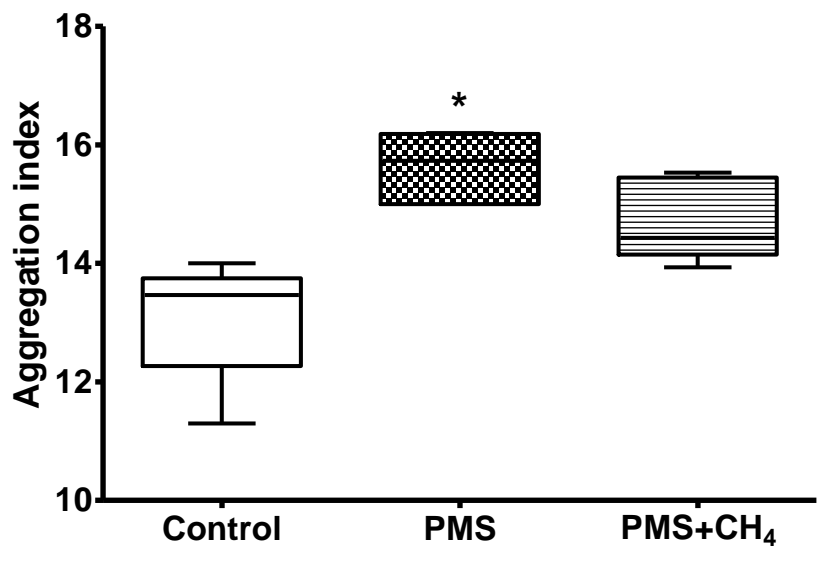

Figure 16. RBC aggregation. The light-transmission of rapidly aggregating samples at low shear rates was measured for $10 \mathrm{~s}$ and the aggregation index was calculated. Control samples (empty boxes), samples incubated with PMS for 2 hours to induce oxidative stress (PMS groups, checkered boxes) and blood samples treated with a normoxic $\left(21 \% \mathrm{O}_{2}\right)$ gas mixture containing $2.2 \% \mathrm{CH}_{4}$ for 10 min after $2 \mathrm{~h}$ of PMS challenge (PMS+CH 4 , hatched boxes). The plots show the median and the $25^{\text {th }}$ and $75^{\text {th }}$ percentiles. Here, * means $\mathrm{p}<0.05$ PMS $v s$ sham-operated group and $\mathrm{n}=4-5$. 


\section{Discussion}

The main purpose of the thesis was to summarize and interpret previous data on the in vivo properties of exogenous $\mathrm{CH}_{4}$ in order to design and conduct further experiments, which help to extend our knowledge on the possible role and mechanisms of action of $\mathrm{CH}_{4}$ in mammalians. Today it is recognized that a variety of enzymes are generating gas mediators, molecules that exert important physiological functions. Also, there is a growing body of evidence which suggests that $\mathrm{CH}_{4}$ can be produced in the eukaryotic cell. The antiinflammatory potential of exogenously supplemented $\mathrm{CH}_{4}$ has been repeatedly confirmed as well, but it is still unclear whether endogenous $\mathrm{CH}_{4}$ levels are able to influence physiological or pathophysiological processes and important details of the mechanism of action still need to be clarified. In fact, there is an apparent difference between the amounts of $\mathrm{CH}_{4}$ produced endogenously and the concentrations used exogenously, which might raise concerns about the physiological relevance of $\mathrm{CH}_{4}$ as a gas messenger. From a pharmacological aspect, however, this is not a critical issue. Understanding the mechanism of action is the key to efficient and safe therapies, and on the basis of accumulated knowledge, the presumed physiological role of a compound can be clarified. In this work, the efficiency of a $\mathrm{CH}_{4}$-based therapy was investigated in a small animal model of oxido-reductive stress and in a second step of accompanying in vitro studies, we tried to delineate a feasible mechanism of action. We should note that the results still cannot fully explain the effectiveness of $\mathrm{CH} 4$, but they rather reflect the multifaceted responses of complex biological systems.

\section{The kinetics of $\mathrm{CH}_{4}$ transport in vivo}

In the case of $\mathrm{NO}$ or $\mathrm{H}_{2} \mathrm{~S}$, precursors stimulating endogenous release of the gas can be administered or enzymatic synthesis of the compounds can be induced (Szczesny et al., 2014; Gero et al., 2016). However, with $\mathrm{CH}_{4}$, direct delivery is the only feasible option. One approach to apply effective $\mathrm{CH}_{4}$ doses is by the enrichment of fluids, saline or other physiological solutions with the gas (Shen et al., 2016; Xin et al., 2016; Zhang et al., 2016). This delivery method is similar to $\mathrm{H}_{2}$-rich saline administration, which has been repeatedly used in vivo in animal models (Mao et al., 2009; Zheng et al., 2009; Chen et al., 2015). While giving the right dose may be easier, the storage of supersaturated $\mathrm{CH}_{4}$-containing solutions might be challenging problem. Another important issue is the relatively low solubility of $\mathrm{CH}_{4}$ in aqueous solutions, and this limits the amount of $\mathrm{CH}_{4}$ which can be administered intravenously or intraperitoneally. Nevertheless, for chronic treatments it may be the method of choice, since $\mathrm{CH}_{4}$ can be given in repeated bolus doses. 
In our studies, gas inhalation was used with artificial air containing $21 \% \mathrm{O}_{2}$ and 2.22.5\% $\mathrm{CH}_{4}$. The solubility of $\mathrm{CH}_{4}$ is rather low in water, but much higher in the lipid phase, hence we hypothesized that inhalation provides a quick way of saturating tissues with $\mathrm{CH}_{4}$. The large alveolar surface of the lungs and the thin layer of alveolar cells with adjacent endothelium provide an ideal way to dissolve $\mathrm{CH}_{4}$ in the blood. Red blood cells contribute to $40-50 \%$ of the total volume of the circulating blood; therefore erythrocyte lipid membranes are good candidates to carry the gas. Also, it has been shown that in this concentration range, $\mathrm{CH}_{4}$ in the inhaled air has no measurable impact on $\mathrm{O}_{2}$ delivery and saturation (Boros et al., 2012).

Despite the fact that the efficacy of $\mathrm{CH}_{4}$ after inhalation has already been demonstrated in different animal models of diseases, the distribution of the molecule has yet to be determined. With this in mind, we sought to assess the kinetics of tissue and blood levels of $\mathrm{CH}_{4}$ during and after the inhalation protocol was used in vivo (see figures $3 \mathrm{~A}$ and $3 \mathrm{~B}$ ). $\mathrm{We}$ found that even a brief inhalation of $\mathrm{CH}_{4}$ resulted in high amounts of gas being dissolved and transported by the blood. Due to the apolar property of the molecule, the majority of gas is transported by RBCs (and lipoproteins) and was reasonable to suppose that the dissolved $\mathrm{CH}_{4}$ influences properties of the $\mathrm{RBC}$ membrane. Upon reperfusion, the $\mathrm{CH}_{4}$ content of the systemic blood immediately starts to equilibrate with the $\mathrm{CH}_{4}$ level in the previously ischemic tissue, reducing the time needed to reach the target cells.

In parallel with blood $\mathrm{CH}_{4}$ measurements, levels of the gas in the intestinal tissue were also assessed. There was a slight increase in $\mathrm{CH}_{4}$ levels during ischemia as a consequence of the omnidirectional diffusion of the gas. Due to its non-polar properties, $\mathrm{CH}_{4}$ can reach tissues without perfusion; hence it can exert effects under deep hypoxia. Upon reperfusion, as the blood flow restarted in the tissue, the levels of the gas rose significantly. Thereafter, about 50 min after the end of normoxic $\mathrm{CH}_{4}$ inhalation no $\mathrm{CH}_{4}$ is measurable either in blood or in the intestine. One limitation is that direct measurement of the actual levels of $\mathrm{CH}_{4}$ dissolved in the tissue is not possible using the methods described here. In our study the headspace gas concentrations were measured over $10 \mathrm{~min}$, during which the previously dissolved blood or tissue $\mathrm{CH}_{4}$ continuously equilibrated between the samples and the gas phase. During inhalation, the intracellular levels are definitely higher than the amounts measured.

\section{The bioactivity of exogenous $\mathrm{CH}_{4}$ in the intestine}

Enterocytes are energetically very active, and there is a delicate steady-state of cell loss and re-epithelialization in the small intestine. The maintenance of physical and immunological barriers between the interior milieu and intestinal lumen is of vital importance, 
but the intestine is sensitive to hypoxia and the GI system is among the most vulnerable organs during circulatory redistributions (Vajda et al., 2004). Although small fluctuations of metabolites can be compensated by high-energy phosphate systems within the cells of the bowel (Kitzenberg et al., 2016), longer periods of ischemia or ischemia followed by a rapid reestablishment of the blood flow leads to severe damage.

The anti-inflammatory properties of $\mathrm{CH}_{4}$ have already been examined in intestinal IR (Boros et al., 2012) and we sought to look at the function of mucosal barrier in this setting. Here we could show that even a brief, 15-min normoxic $\mathrm{CH}_{4}$ treatment modulated epithelial component of transmucosal permeability significantly and effectively prevented the IRinduced barrier loss in the early reperfusion phase (see figures $4 \mathrm{~A}$ and $4 \mathrm{~B}$ ). The rationale behind the timing and dosage of $\mathrm{CH}_{4}$ treatment was provided by the previous reports.

The assessment of the lumen-to-plasma clearance of the $4 \mathrm{kDa}$ MW FITC-labelled dextrane allowed us to determine paracellular permeability, mediated predominantly by TJs (Szabo et al., 2006). TJs are membrane-bound protein complexes connected to the cytoskeleton (Laukoetter et al., 2006). The maintenance of the closed conformation is energy dependent; therefore deteriorating intracellular ATP levels increase permeability (Wattanasirichaigoon et al., 1999). $\mathrm{CH}_{4}$ can in theory protect TJs from opening by directly influencing membrane fluidity or by preserving the ATP levels of epithelial cells; moreover, it can act indirectly, such as by a NO-mediated mechanism. Actually, the reduction of tissue NTyr levels does indeed suggest that $\mathrm{CH}_{4}$ may improve the epithelial barrier function by limiting the inhibitory effect of NO on mitochondrial electron transport chain complexes I and IV (Brown, 2001). This, in turn, may elevate ATP production early in the reperfusion phase, allowing cells to attain sufficiently high energy levels to maintain TJ proteins in the tightly closed conformation.

In parallel with the improved barrier function, both conventional histology and CLSEM revealed preserved structure of the most luminal layers of the mucosa (see figures 10 and 11). There is a multitude of factors contributing to mucosal injury upon reperfusion (Granger et al., 2015). In the current protocol the decrease in epithelial permeability after $\mathrm{CH}_{4}$ inhalation was associated with reduced ROS and RNS generation and decreased ET-1 levels. In addition the $\mathrm{CH}_{4}$ treatment influenced the PMN infiltration, a specific cellular component of inflammatory reactions (figures 8 and 9). $\mathrm{CH}_{4}$ treatment improved both serosal microcirculation and the SMA flow facilitating oxygen delivery to cells and allowing effective oxidative phosphorlylation in mitochondria (see figures 6 and 7). The normalized 
ET-1 plasma levels in the $\mathrm{CH}_{4}$-treated groups may reflect the improved local microcirculatory state on one hand and reduced inflammatory activation on the other hand.

There are, however, other links between the improved functional and structural status of the GI mucosa upon $\mathrm{CH}_{4}$-treatment. It was shown previously that normoxic $\mathrm{CH}_{4}$ treatment modulated XOR-derived $\mathrm{O}_{2}^{\bullet-}$ (Boros et al., 2012). However, extracellular, XOR-derived $\mathrm{O}_{2}{ }^{\bullet-}$ can activate PMNs through the TLR4 - NF- $\kappa B$ pathway (Lorne et al., 2008). The significantly reduced ROS and RNS levels $\left(\mathrm{O}_{2}{ }^{\bullet-}\right.$ and NTyr) after $\mathrm{CH}_{4}$ treatment can further prevent overwhelmed PMN activation and, as a consequence, the consumption of $\mathrm{O}_{2}$ by NADPH oxidase. Since one of the main determinants of mucosal microcirculation during reperfusion is an enhancement of the interactions between leukocytes and the endothelium (Vollmar et al., 2011), a reduced number of activated PMNs can readily improve tissue perfusion.

Early barrier dysfunction is a crucial in the development of delayed and remote organ injury following mesenteric IR. Postischemic gut serves as an incubator, where endotoxin leaking from the lumen to the interstitium primes PMNs (Moore et al., 1994). Significantly, the direct effect of normoxic $\mathrm{CH}_{4}$ on NADPH oxidase activation was shown earlier (Boros 2012, Mészáros, unpublished data). This observation is in agreement with the findings presented in a recent publication of Zhang and coworkers, who provided conclusive evidence that $\mathrm{CH}_{4}$-enriched saline solution suppresses TLR4-induced nuclear factor-kappa B (NF- $\mathrm{B}$ ) / mitogen-activated kinase (MAPK) activation in cultured macrophages.

The study design allowed us to determine the barrier function immediately after reperfusion and in the later phases, the effects of $\mathrm{CH}_{4}$ inhalation were also studied $60 \mathrm{~min}$ and $180 \mathrm{~min}$ after the restoration of the mesenteric blood flow. The epithelial barrier of the ileum was already partially restored in the later phase of the reperfusion, as indicated by the lower FD4 clearances (see Figure 4.). In fact, the restoration of the epithelial barrier is a remarkably speedy process, involving the flattening of epithelial cells to cover injured villus surface and the shrinkage of the villi to reduce the damaged area (Derikx et al., 2008; Matthijsen et al., 2009; Grootjans et al., 2011). Improved micro- and macrocirculation, restored $\mathrm{O}_{2}$ supply and the normalization of the energetic state of the intestinal cells can all contribute to the efficacy of this process, leading to the closure of TJs. However, the difference between the intensities of early and later changes in epithelial permeability suggest that upon re-establishment of the blood and oxygen supply, the endogenous defense mechanisms cannot immediately control or counteract the damaging reactions. Salvage therapies should target the initial steps to avoid long-term or distant consequences of the barrier damage, and $\mathrm{CH}_{4}$ treatment can fill this need. 
Even a brief 15-min $\mathrm{CH}_{4}$ inhalation preserved the function of the postischemic gut, hence continuous or longer $\mathrm{CH}_{4}$ supplementation might have additional beneficial effects.

The effects of $\mathrm{CH}_{4}$ on the IR-induced changes in vascular permeability are less clear because in this model the epithelial and endothelial permeability-specific changes were affected differentially by the IR cycle. Epithelial permeability significantly deteriorated immediately after reperfusion, while the extravasation of the circulating endothelial tracer did not increase to a great extent. Hence, the relative effect of $\mathrm{CH}_{4}$ administration on microvascular permeability could not been evaluated simultaneously. Nevertheless, possible technical limitations (i.e. interaction between FITC-labeled dextrane and Evans blue measurements) cannot be ruled out. The epithelial and endothelial permeability measurements were conducted simultaneously in the same animal for technical and ethical reasons, and this approach could influence the sensitivity of these methods. Therefore, future studies are needed to examine the influence of $\mathrm{CH}_{4}$ on microvascular permeability directly and separately.

\section{The detection of NO in biological samples}

Along the above lines, one might suppose that $\mathrm{CH}_{4}$ accumulates transiently at membrane interfaces, and a disproportionate increase in relationship with other gases, such as NO, may alter enzyme-linked processes, and ultimately mitochondrial function. Although much is known about the role of NO in physiology and pathophysiology, the determination of its actual levels in biological samples is not an easy task. NO has a half-life of milliseconds in tissues, much shorter than other inflammatory mediators. The determination of $\mathrm{NO}_{2}{ }^{-} / \mathrm{NO}_{3}{ }^{-}$ amounts by the Griess reaction or with chemiluminescence methods with higher sensitivity is an option, but in hypoxia, when nitrite reductases consume $\mathrm{NO}_{2}{ }^{-}$, these can lead to erroneous results (Griendling et al., 2016). EPR spectroscopy is currently the most suitable method used to measure NO directly. It has very high specificity for NO as it forms complexes with exogenously added spin traps (e.g. Na-DETC and $\mathrm{FeSO}_{4}$ ). Unfortunately, these compounds are toxic. Moreover, such molecules can interfere with endogenous NO utilizing pathways through their high affinity to NO.

An alternative is to utilize endogenous traps of NO for this purpose. Intracellularly produced NO reacts with ferrous ions to form dinitrosyl-iron complexes (NO-Fe) (Sergent $e t$ al., 2005). In contrast, in the vasculature NO forms mononitrosyl-hemoglobin complexes (NO-Hb) (Gow et al., 1998) with hemoglobin. Since no ferrous ions occur in the blood, the two complexes, located at $\mathrm{g}=2.075$ and $\mathrm{g}=2.042$ are characteristic for $\mathrm{NO}-\mathrm{Hb}$ and $\mathrm{NO}-\mathrm{Fe}$, respectively. 
LPS administration is a standard way of inducing acute TLR4 - NF- $\mathrm{BB}-$ mediated inflammation. We were able to demonstrate in intact, non processed, frozen samples that LPS increased hepatic NO levels in a dose-dependent way, both in the intracellular and intravascular compartments and $\mathrm{NO}-\mathrm{Hb}$ levels in the systemic circulation (see Figure 12). The concentrations of NO in naturally occurring complexes were substantially lower compared with previous values stated in the literature of intracellular NO using the specific NO trap iron-diethylthiocarbamate in a similar model (Kozlov et al., 2005). We may conclude that only part of NO produced intracellularly is scavenged by dinitrosyl-iron complexes and the residual NO contributes to physiological NO signaling or diffuses in the blood (Kozlov et al., 2001a).

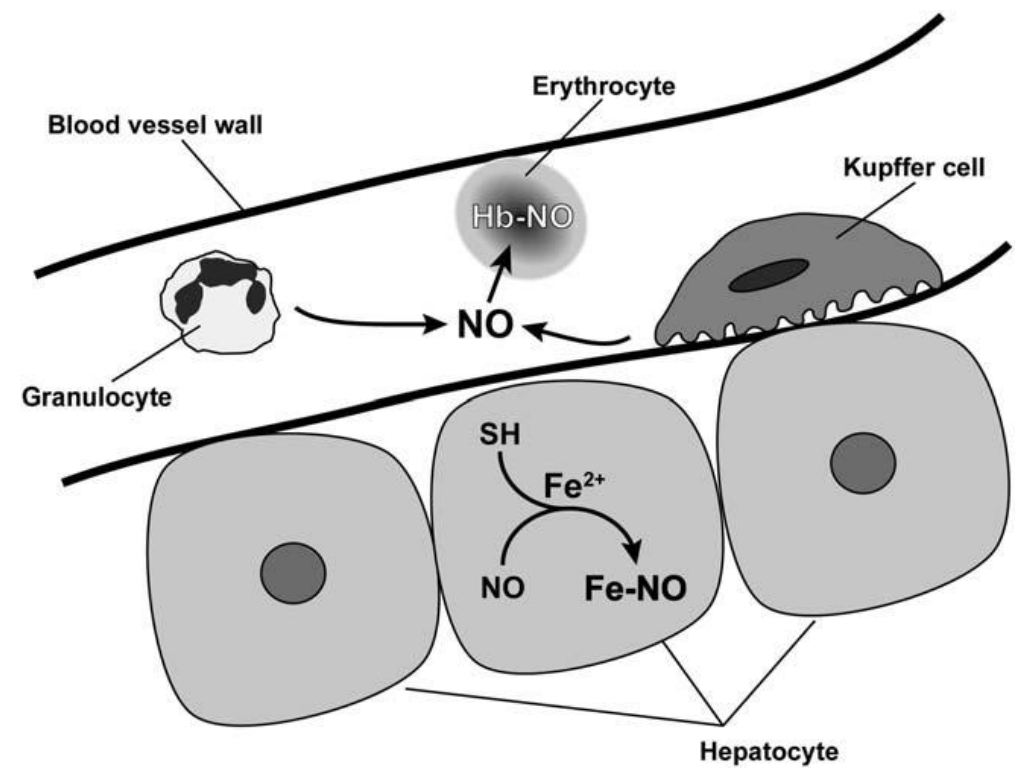

Figure 17. Endogenous traps of NO inside parenchymal cells and small blood vasculature of the liver. This scheme shows that $\mathrm{NO}-\mathrm{Hb}$ complexes predominantly reflect extracellular NO generation by immune cells, whereas NO-Fe is a matter of intracellular NO synthesis. After being synthesized by hepatocytes, $\mathrm{NO}$ is trapped by ferrous ions $\left(\mathrm{Fe}^{2+}\right)$ from the cytosolic free iron pool, which forms a dinitrosyl-iron complex (NO-Fe) with two NO molecules and two thiol groups of proteins ( $\mathrm{SH})$. We assume that a small fraction of the NO molecules synthesized in hepatocytes diffuses into the microvasculature, where together with the NO molecules synthesized by immune cells (granulocytes, Kupffer cells), it forms mononitrosyl-hemoglobin complexes (NO-Hb).

\section{The interaction of $\mathrm{CH}_{4}$ with NO-related nitrosative stress}

NO is an exemplary double edged sword in biology. In nanomolar concentrations it is vasorelaxant and antiadhesive, but in the micromolar range NO inhibits mitochondrial respiration in a reversible way (Cooper et al., 2007; Cooper et al., 2008). It is unlikely that NO can inhibit cytochrome c oxidase during normoxia due to the high $\mathrm{K}_{\mathrm{M}}$ of the enzyme for NO. But under hypoxia and with high NO concentrations it is a possible pathway. In parallel, the half-life of $\mathrm{NO}$ is substantially longer if $\mathrm{O}_{2}$ levels are low (Thomas et al., 2001). In fact, 
elevated NO levels could be present during the ischemic phase, as data obtained by means of EPR indicates. With $\mathrm{CH}_{4}$ treatment, however, the overproduction of $\mathrm{NO}$ could be reduced (see Figure 13). Significantly, we detected NTyr formation in the intestinal tissue, an indicator of ONOO, which requires both $\mathrm{O}_{2}{ }^{\bullet-}$ and NO to form. The non-specific nitration of ETS proteins by ONOO is an additional, non-reversible inhibition of mitochondrial OXPHOS (Brown et al., 2004). Thus, the reduction of NTyr levels after $\mathrm{CH}_{4}$ treatment is an indirect sign of the influence of mitochondrial and NO-linked reactions.

The source of $\mathrm{NO}$ under hypoxia is thought to be $\mathrm{NO}_{2}{ }^{-}$, reduced mostly by enzymatic reactions and by small molecules under acidic $\mathrm{pH}$. Apart from hemoglobin within RBCs and the mitochondrial ETC itself $\mathrm{XO}$ acts as $\mathrm{NO}_{2}^{-}$reductase as well. It has been shown that $\mathrm{CH}_{4}$ inhibits XOR under normoxic conditions, a feature which has important role in alleviating ROS-induced damage during reperfusion, when $\mathrm{XO}$ is one of the main ROS generating enzymes. The same enzyme can function as $\mathrm{NO}_{2}{ }^{-}$reductase under hypoxia and low $\mathrm{pH}$, conditions, which are fulfilled during ischemia.

Considering this information, we set out to measure NO release in real-time in vitro from liver tissue homogenate under anoxic conditions, mimicking ischemic tissue. After addition of $\mathrm{Na}_{-} \mathrm{NO}_{2}^{-}$as a source of $\mathrm{NO}$, in the anoxic- $\mathrm{CH}_{4}$-incubated group, the production rate of NO was significantly lower than that with $\mathrm{N}_{2}$ atmosphere only (see Figure 14). Endogenous levels of $\mathrm{XDH}$ are similarly high in the liver and in the small intestine. Accordingly, it can be assumed that modulation of $\mathrm{XO}$ by $\mathrm{CH}_{4}$ contributes to the reduced $\mathrm{NO}$ levels, but other mechanisms cannot be excluded with certainty. How exactly $\mathrm{CH}_{4}$ regulates NO levels is still unclear, but the interaction of the molecule with any of the $\mathrm{O}_{2}$-dependent NOS isoforms seems unlikely, considering the deep hypoxia during ischemia. Nevertheless, modulation of iNOS induction during the reperfusion cannot be ruled out.

Taken together, we were able to demonstrate that increased $\mathrm{CH}_{4}$ input reduces NO production and NTyr levels in hypoxic organs and in tissue homogenates under anoxia. Apparently, there is a contradiction between the reduction of anoxic/hypoxic NO generation and improved microcirculation upon reperfusion. Nevertheless, the maximal vasodilating effect of NO requires much lower levels than those needed for inhibition of cytochrome c oxidase. What is more, it was demonstrated previously that intracellular NO readily diffuses out from the cells in the circulation, but intravascular NO does not diffuse into the cells (Kozlov et al., 2001a). Spatial differences of NO production and utilization thus play a substantial role, but the explanation of this phenomenon requires more study. 


\section{The direct action of $\mathrm{CH}_{4}$ on erythrocyte deformability}

The tissue NTyr level is an indicator of protein nitration, associated with elevated ONOO levels. ONOO is a potent initiator of membrane lipid peroxidation (Hogg et al., 1999) and it was reported earlier that IR-associated lipid peroxidation decreases membrane fluidity in various tissues (Dobretsov et al., 1977) and in erythrocytes as well (Watanabe et al., 1990). RBCs are rich in iron, which catalyzes ROS formation through the Fenton-reaction, making them highly susceptible to IR damage (McCord, 1985; Baskurt et al., 1998; Nanobashvili et $a l .$, 2002). The membrane and cytoskeleton are together responsible for altering the shape of erythrocytes (Reinhart, 2001). Lipid peroxidation breaks the connection between the two components (Mohandas et al., 1993) and, consequently, both deformability and aggregation of the RBCs is influenced in a detrimental way (Kayar et al., 2001). Brath et al. reported worsened RBC deformability and increased aggregation in the early reperfusion after experimental mesenteric ischemia in the rat portal vein (Brath et al., 2010). Normal erythrocytes are approximately $25 \%$ larger than the mean diameter of capillaries, so RBC deformability is a prerequisite in normal capillary blood flow (Reinhart et al., 1985; Baskurt et al., 2003).

Based on this background, we evaluated RBC velocity as a measure of perfusion in the serosal microvessels, and direct intravital data were obtained on the deranged intestinal microcirculation. Furthermore, $\mathrm{CH}_{4}$ inhalation was associated with improved serosal microcirculation and the treatment also influenced the SMA flow. Hence, we hypothesized that $\mathrm{CH}_{4}$ can modulate erythrocyte deformability upon being dissolved in the membrane and it may restore the bullet-shaped RBCs and allow them to flow freely through microvessels, thus improving microcirculation. With this in mind, an in vitro microrheological study with human whole blood was designed without the confounding in vivo effects of vasoactive metabolites. From methodological considerations, PMS, an oxidizing agent was used prior to normoxic $\mathrm{CH}_{4}$ treatments, an approach analogous to in vivo $\mathrm{CH}_{4}$ application during the reperfusion phase only. We demonstrated that PMS incubation significantly reduced the elongation index of RBCs, thereby confirming the contribution of lipid peroxidation in this model system (see Figure 15). Upon normoxic $\mathrm{CH}_{4}$ treatment, the $\mathrm{RBC}$ deformability improved at low-tomoderate shear stress rates, suggesting a direct effect of $\mathrm{CH}_{4}$ on membrane fluidity and/or membrane-cytoskeleton junctions.

Some studies claim that pathological RBC aggregation plays an even greater role in microcirculatory dysfunctions. Therefore, aggregation was measured in the same experimental setting at low shear stress rates. Once again, the increased aggregation index of 
RBCs provided evidence for the role of oxidative stress in our set-up; and $\mathrm{CH}_{4}$ treatment alleviated this response (see Figure 16). Moreover, with higher PMS concentrations, the effect of $\mathrm{CH}_{4}$ treatment was even more pronounced (data not shown). Thus, these data provide evidence for the direct effects of $\mathrm{CH}_{4}$ exerted in biomembranes of erythrocytes. Interestingly, $\mathrm{XO}$ inhibition with allopurinol prevents the RBC rigidity changes after IR in vivo (Nemeth et al., 2006). Since $\mathrm{CH}_{4}$ is able to inhibit XO (Boros et al., 2012), an improvement of the microcirculation upon $\mathrm{CH}_{4}$ treatment is the net result of a complex mechanism, inhibition of $\mathrm{XO}$ leads to a decreased $\mathrm{O}_{2}{ }^{\bullet-}$ production and less membrane damage, while, at the same time, the accumulation of $\mathrm{CH}_{4}$ in the lipid phase further increases $\mathrm{RBC}$ deformability. 


\section{Summary of the new findings}

Previous reports with exogenously administered $\mathrm{CH}_{4}$ corroborated the findings on the antiinflammatory effects of the molecule, showing alleviated TNF- $\alpha$, IL-6, IL-1 $\beta$ levels, improved antioxidative defense mechanisms and reduced signs of oxidative damage. Based on these results two hypotheses for the mechanism of action were formulated and tested.

1. $\mathrm{CH}_{4}$ is quickly transported from the lungs to the small intestine by the circulating blood. After the inhalation of normoxic air containing 2.2\% $\mathrm{CH}_{4}$ blood concentration of $\mathrm{CH}_{4}$ increases at least 2-3-fold over its basal levels; this increase is sufficient to modulate the generation of ROS and RNS.

2. The early and later consequences of intestinal IR were characterized by biochemical, macro- and microcirculatory and morphological parameters. The IR-induced circulatory and structural damage was accompanied by increased epithelial permeability, demonstrating mucosal barrier damage. Normoxic $\mathrm{CH}_{4}$ inhalation effectively prevented the elevation of intestinal epithelial permeability, maintaining structural integrity of the mucosa and improving biochemical signs of inflammation in the early reperfusion. These data support previous findings on $\mathrm{CH}_{4}$ bioactivity and establish a mucosa-protective role for exogenous $\mathrm{CH}_{4}$ to modulate the IR-induced pro-inflammatory activity locally in the small intestine.

3. A new, toxic spin trap-free EPR spectroscopy method was developed for NO detection. The method was validated for NO measurements from both the intra- and extracellular compartments of the same samples in tissue biopsies.

4. With EPR spectroscopy reduced NO levels were detected in the intestinal tissue after normoxic $\mathrm{CH}_{4}$ administration, and this finding was supported by in vitro data collected in anoxic liver tissue during $\mathrm{CH}_{4}$ incubation. Collectively, these results confirm that exogenous $\mathrm{CH}_{4}$ administration effectively reduces NO levels in the ischemic tissue.

5. The results of this study revealed that $\mathrm{CH}_{4}$ in vitro improves the deformability of red blood cells during simulated oxidative stress, which may contribute to the improvement of the effectiveness of mesenteric microcirculation in the postischemic small intestine. 


\section{Acknowledgements}

First and foremost, I would like to express my sincere gratitude to Professor Mihály Boros, to my supervisor and mentor for his continuous support and patience during my years in the Institute of Surgical Research. His gentle way of stimulating guidance, optimistic attitude and protecting atmosphere let me grow and follow my curiosity.

I owe special thanks to Professor Andrey V. Kozlov, my supervisor in Vienna, for his encouragement, practical and theoretical advices. His immense knowledge was indispensable to this thesis.

I would like to thank Professor József Kaszaki for his practical guidance and help over years. Likewise, supervision and help of Dr. Gabriella Varga and Dr. Borbála Fazekas during and after my university years is greatly appreciated. I express my special thanks to Professor Andrea Szabó for her always professional, friendly and extremely useful suggestions. I wish to thank Dr. Tamás Büki and Dr. Kitti Horváth for taking me to the Institute of Surgical Research on a sunny morning of September, 2008. That's where everything got started.

I would like to acknowledge the highest level professional help and personal support of Dr. Adelheid Weidinger. Special thanks go to Sergiu D. Dumitrescu, M.Sc., for being my best friend and excellent colleague in Vienna in hard times and in minutes of joy.

I am indebted to Professors Heinz Redl, Head of the Ludwig Boltzmann Institute for Experimental and Clinical Traumatology, Soheyl Bahrami, Marcin F. Osuchowski and Peter Dungel for generous and continuous support of my work in Vienna.

I would like to give my sincere thanks to Professor László Tretter and his team, who engrafted me with the beautiful world of mitochondria.

This work would not have been possible without the efforts all of my coworkers, collaborators and the technical staff at the Institute of Surgical Research (Szeged), Ludwig Boltzmann Institute for Experimental and Clinical Traumatology (Vienna) and First Department of Medicine (Pécs). I especially thank to Dr. Stefan Puchner and Tanja Stögerer, B.Sc. for their skillful assistance.

Lastly, but most importantly, I would like to thank my parents and my family for their never-ending encouragement and relief. My goals could not be accomplished without such a strong background.

This thesis was supported by research grants of the Hungarian Science Research Fund OTKA K104656, the National Research Development and Innovation Office NKFI K120232 and GINOP-2.3.2-15-2016-00015. 


\section{List of references}

1. Åhrén C, Haglund U. Mucosal Lesions in the Small Intestine of the Cat during Low Flow. Acta Physiol. Scand. 1973; 88:541-550.

2. Andrews P, Bray RC, Edwards P, Shooter KV. The chemistry of xanthine oxidase. 11. Ultracentrifuge and gel-filtration studies on the milk enzyme. Biochem. J. 1964; 93:627-632.

3. Andreyev AY, Kushnareva YE, Starkov AA. Mitochondrial metabolism of reactive oxygen species. Biochemistry (Moscow) 2005; 70:200-214.

4. Baskurt OK, Meiselman HJ. Blood rheology and hemodynamics. Semin. Thromb. Hemost. 2003; 29:435-450.

5. Baskurt OK, Temiz A, Meiselman HJ. Effect of superoxide anions on red blood cell rheologic properties. Free Radic. Biol. Med. 1998; 24:102-110.

6. Beckman JS, Beckman TW, Chen J, Marshall PA, Freeman BA. Apparent hydroxyl radical production by peroxynitrite: implications for endothelial injury from nitric oxide and superoxide. Proc. Natl. Acad. Sci. U. S. A. 1990; 87:1620-1624.

7. Bernardi P, Rasola A, Forte M, Lippe G. The Mitochondrial Permeability Transition Pore: Channel Formation by F-ATP Synthase, Integration in Signal Transduction, and Role in Pathophysiology. Physiol. Rev. 2015; 95:1111-1155.

8. Blachier F, Boutry C, Bos C, Tomé D. Metabolism and functions of 1-glutamate in the epithelial cells of the small and large intestines. Am. J. Clin. Nutr. 2009; 90:814S-821S.

9. Blouin JM, Penot G, Collinet M, Nacfer M, Forest C, Laurent-Puig P, Coumoul X, Barouki R, Benelli C, Bortoli S. Butyrate elicits a metabolic switch in human colon cancer cells by targeting the pyruvate dehydrogenase complex. Int. J. Cancer 2011; 128:2591-2601.

10. Boros M, Ghyczy M, Erces D, Varga G, Tokes T, Kupai K, Torday C, Kaszaki J. The antiinflammatory effects of methane. Crit. Care Med. 2012; 40:1269-1278.

11. Boros M, Tuboly E, Meszaros A, Amann A. The role of methane in mammalian physiology-is it a gasotransmitter? J. Breath Res. 2015; 9:014001.

12. Bourque SL, Davidge ST, Adams MA. The interaction between endothelin-1 and nitric oxide in the vasculature: new perspectives. Am. J. Physiol. Regul. Integr. Comp. Physiol. 2011; 300:R1288-1295.

13. Brath E, Nemeth N, Kiss F, Sajtos E, Hever T, Matyas L, Toth L, Miko I, Furka I. Changes of local and systemic hemorheological properties in intestinal ischemia-reperfusion injury in the rat model. Microsurgery 2010; 30:321-326.

14. Brown GC. Regulation of mitochondrial respiration by nitric oxide inhibition of cytochrome $\mathrm{c}$ oxidase. Biochim. Biophys. Acta 2001; 1504:46-57.

15. Brown GC, Borutaite V. Inhibition of mitochondrial respiratory complex I by nitric oxide, peroxynitrite and S-nitrosothiols. Biochim. Biophys. Acta 2004; 1658:44-49.

16. Brown GC, Borutaite $\mathrm{V}$. There is no evidence that mitochondria are the main source of reactive oxygen species in mammalian cells. Mitochondrion 2012; 12:1-4.

17. Brown GC, Cooper CE. Nanomolar concentrations of nitric oxide reversibly inhibit synaptosomal respiration by competing with oxygen at cytochrome oxidase. FEBS Lett. 1994; 356:295-298.

18. Bush KT, Keller SH, Nigam SK. Genesis and reversal of the ischemic phenotype in epithelial cells. J. Clin. Invest. 2000; 106:621-626.

19. Campbell EL, Bruyninckx WJ, Kelly CJ, Glover LE, McNamee EN, Bowers BE, Bayless AJ, Scully M, Saeedi BJ, Golden-Mason L, Ehrentraut SF, Curtis VF, Burgess A, Garvey JF, Sorensen A, Nemenoff R, Jedlicka P, Taylor CT, Kominsky DJ, Colgan SP. Transmigrating neutrophils shape the mucosal microenvironment through localized oxygen depletion to influence resolution of inflammation. Immunity 2014; 40:66-77. 
20. Cantrell CA, Shetter RE, McDaniel AH, Calvert JG, Davidson JA, Lowe DC, Tyler SC, Cicerone RJ, Greenberg JP. Carbon kinetic isotope effect in the oxidation of methane by the hydroxyl radical. J. Geophys. Res. Atmos. 1990; 95:22455-22462.

21. Cassina A, Radi R. Differential inhibitory action of nitric oxide and peroxynitrite on mitochondrial electron transport. Arch. Biochem. Biophys. 1996; 328:309-316.

22. Cavaillon JM, Annane D. Compartmentalization of the inflammatory response in sepsis and SIRS. J. Endotoxin Res. 2006; 12:151-170.

23. Chance B, Hollunger G. The interaction of energy and electron transfer reactions in mitochondria. I. General properties and nature of the products of succinate-linked reduction of pyridine nucleotide. J. Biol. Chem. 1961; 236:1534-1543.

24. Chen O, Ye Z, Cao Z, Manaenko A, Ning K, Zhai X, Zhang R, Zhang T, Chen X, Liu W, Sun X. Methane attenuates myocardial ischemia injury in rats through anti-oxidative, anti-apoptotic and anti-inflammatory actions. Free Radic. Biol. Med. 2016; 90:1-11.

25. Chen Y, Zong C, Guo Y, Tian L. Hydrogen-rich saline may be an effective and specific novel treatment for osteoradionecrosis of the jaw. Ther. Clin. Risk Manag. 2015; 11:1581-1585.

26. Chouchani ET, Pell VR, Gaude E, Aksentijevic D, Sundier SY, Robb EL, Logan A, Nadtochiy SM, Ord ENJ, Smith AC, Eyassu F, Shirley R, Hu C-H, Dare AJ, James AM, Rogatti S, Hartley RC, Eaton S, Costa ASH, Brookes PS, Davidson SM, Duchen MR, Saeb-Parsy K, Shattock MJ, Robinson AJ, Work LM, Frezza C, Krieg T, Murphy MP. Ischaemic accumulation of succinate controls reperfusion injury through mitochondrial ROS. Nature 2014; 515:431-435.

27. Citalan-Madrid AF, Garcia-Ponce A, Vargas-Robles H, Betanzos A, Schnoor M. Small GTPases of the Ras superfamily regulate intestinal epithelial homeostasis and barrier function via common and unique mechanisms. Tissue Barriers 2013; 1:e26938.

28. Colgan SP, Curtis VF, Lanis JM, Glover LE. Metabolic regulation of intestinal epithelial barrier during inflammation. Tissue Barriers 2015; 3:e970936.

29. Conrad R, Klose M. Anaerobic conversion of carbon dioxide to methane, acetate and propionate on washed rice roots. FEMS Microbiol. Ecol. 1999; 30:147-155.

30. Cooper CE, Brown GC. The inhibition of mitochondrial cytochrome oxidase by the gases carbon monoxide, nitric oxide, hydrogen cyanide and hydrogen sulfide: chemical mechanism and physiological significance. J. Bioenerg. Biomembr. 2008; 40:533-539.

31. Cooper CE, Giulivi C. Nitric oxide regulation of mitochondrial oxygen consumption II: Molecular mechanism and tissue physiology. Am. J. Physiol. Cell Physiol. 2007; 292:C19932003.

32. Cuzzocrea S, Zingarelli B, Costantino G, Szabo A, Salzman AL, Caputi AP, Szabo C. Beneficial effects of 3-aminobenzamide, an inhibitor of poly (ADP-ribose) synthetase in a rat model of splanchnic artery occlusion and reperfusion. Br. J. Pharmacol. 1997; 121:1065-1074.

33. Dalsgaard T, Simonsen U, Fago A. Nitrite-dependent vasodilation is facilitated by hypoxia and is independent of known NO-generating nitrite reductase activities. Am. J. Physiol. Heart Circ. Physiol. 2007; 292:H3072-3078.

34. De Caterina R, Libby P, Peng H-B, Thannickal VJ, Rajavashisth T, Gimbrone Jr M, Shin WS, Liao JK. Nitric oxide decreases cytokine-induced endothelial activation. Nitric oxide selectively reduces endothelial expression of adhesion molecules and proinflammatory cytokines. J. Clin. Invest. 1995; 96:60.

35. de Lacy Costello BP, Ledochowski M, Ratcliffe NM. The importance of methane breath testing: a review. J. Breath Res. 2013; 7:024001.

36. Deitch EA, Xu D, Franko L, Ayala A, Chaudry IH. Eidence favoring the role of the gut as a cytokine-generating organ in rats subjected to hemorrhagic shock. Shock 1994; 1:141-145.

37. Derikx JP, Matthijsen RA, de Bruine AP, van Bijnen AA, Heineman E, van Dam RM, Dejong $\mathrm{CH}$, Buurman WA. Rapid reversal of human intestinal ischemia-reperfusion induced damage by shedding of injured enterocytes and reepithelialisation. PLoS One 2008; 3:e3428. 
38. Di Lisa F, Bernardi P. Mitochondria and ischemia-reperfusion injury of the heart: Fixing a hole. Cardiovasc. Res. 2006; 70:191-199.

39. Dobretsov GE, Borschevskaya TA, Petrov VA, Vladimirov YA. The increase of phospholipid bilayer rigidity after lipid peroxidation. FEBS Lett. 1977; 84:125-128.

40. Duranski MR, Greer JJ, Dejam A, Jaganmohan S, Hogg N, Langston W, Patel RP, Yet SF, Wang $\mathrm{X}$, Kevil CG, Gladwin MT, Lefer DJ. Cytoprotective effects of nitrite during in vivo ischemiareperfusion of the heart and liver. J. Clin. Invest. 2005; 115:1232-1240.

41. Érces D, Nógrády M, Varga G, Szücs S, Mészáros AT, Fischer-Szatmári T, Cao C, Okada N, Okada H, Boros M, Kaszaki J. Complement C5a inhibition improves late hemodynamic and inflammatory changes in a rat model of nonocclusive mesenteric ischemia. Surgery 2016; 159:960-971.

42. Erecinska M, Silver IA. Tissue oxygen tension and brain sensitivity to hypoxia. Respir. Physiol. 2001; 128:263-276.

43. Fan D-f, Hu H-j, Sun Q, Lv Y, Ye Z-h, Sun X-j, Pan S-y. Neuroprotective effects of exogenous methane in a rat model of acute carbon monoxide poisoning. Brain Res. 2016; 1633:62-72.

44. Ferdinandy P, Danial H, Ambrus I, Rothery RA, Schulz R. Peroxynitrite Is a Major Contributor to Cytokine-Induced Myocardial Contractile Failure. Circ. Res. 2000; 87:241-247.

45. Furchgott RF. (1988). Studies on relaxation of rabbit aorta by sodium nitrite: the basis for the proposal that the acid-activatable inhibitory factor from retractor penis is inorganic nitrite and the endothelium-derived relaxing factor is nitric oxide In: Vasodilatation: Vascular Smooth Muscle, Peptides, Autonomic Nerves and Endothelium, ed. PM Vanhoutte, New York: Raven Press, $401-$ 414.

46. Furchgott RF, Zawadzki JV. The obligatory role of endothelial cells in the relaxation of arterial smooth muscle by acetylcholine. Nature 1980; 288:373-376.

47. Gadelha FR, Thomson L, Fagian MM, Costa AD, Radi R, Vercesi AE. Ca2+-independent permeabilization of the inner mitochondrial membrane by peroxynitrite is mediated by membrane protein thiol cross-linking and lipid peroxidation. Arch. Biochem. Biophys. 1997; 345:243-250.

48. Galimov ER, Chernyak BV, Sidorenko AS, Tereshkova AV, Chumakov PM. Prooxidant Properties of p66shc Are Mediated by Mitochondria in Human Cells. PLoS One 2014; 9:e86521.

49. Gero D, Torregrossa R, Perry A, Waters A, Le-Trionnaire S, Whatmore JL, Wood M, Whiteman M. The novel mitochondria-targeted hydrogen sulfide (H2S) donors AP123 and AP39 protect against hyperglycemic injury in microvascular endothelial cells in vitro. Pharmacol. Res. 2016; 113:186-198.

50. Ghyczy M, Torday C, Boros M. Simultaneous generation of methane, carbon dioxide, and carbon monoxide from choline and ascorbic acid: a defensive mechanism against reductive stress? FASEB J. 2003; 17:1124-1126.

51. Ghyczy M, Torday C, Kaszaki J, Szabo A, Czobel M, Boros M. Hypoxia-induced generation of methane in mitochondria and eukaryotic cells: an alternative approach to methanogenesis. Cell. Physiol. Biochem. 2008; 21:251-258.

52. Giorgio M, Migliaccio E, Orsini F, Paolucci D, Moroni M, Contursi C, Pelliccia G, Luzi L, Minucci S, Marcaccio M, Pinton P, Rizzuto R, Bernardi P, Paolucci F, Pelicci PG. Electron transfer between cytochrome $\mathrm{c}$ and p66Shc generates reactive oxygen species that trigger mitochondrial apoptosis. Cell 2005; 122:221-233.

53. Glover LE, Bowers BE, Saeedi B, Ehrentraut SF, Campbell EL, Bayless AJ, Dobrinskikh E, Kendrick AA, Kelly CJ, Burgess A, Miller L, Kominsky DJ, Jedlicka P, Colgan SP. Control of creatine metabolism by HIF is an endogenous mechanism of barrier regulation in colitis. Proc. Natl. Acad. Sci. U. S. A. 2013; 110:19820-19825.

54. Glover LE, Lee JS, Colgan SP. Oxygen metabolism and barrier regulation in the intestinal mucosa. J. Clin. Invest. 2016; 126:3680-3688. 
55. Gnaiger E. Oxygen conformance of cellular respiration. A perspective of mitochondrial physiology. Adv. Exp. Med. Biol. 2003; 543:39-55.

56. Godber BLJ, Doel JJ, Sapkota GP, Blake DR, Stevens CR, Eisenthal R, Harrison R. Reduction of Nitrite to Nitric Oxide Catalyzed by Xanthine Oxidoreductase. J. Biol. Chem. 2000; 275:77577763.

57. Goligorsky MS, Tsukahara H, Magazine H, Andersen TT, Malik AB, Bahou WF. Termination of endothelin signaling: role of nitric oxide. J. Cell. Physiol. 1994; 158:485-494.

58. Goodall KJ, Poon IK, Phipps S, Hulett MD. Soluble heparan sulfate fragments generated by heparanase trigger the release of pro-inflammatory cytokines through TLR-4. PLoS One 2014; 9:e109596.

59. Gow AJ, Stamler JS. Reactions between nitric oxide and haemoglobin under physiological conditions. Nature 1998; 391:169-173.

60. Granger DN, Hollwarth ME, Parks DA. Ischemia-reperfusion injury: role of oxygen-derived free radicals. Acta Physiol. Scand. Suppl. 1986a; 548:47-63.

61. Granger DN, Kvietys PR. Reperfusion injury and reactive oxygen species: The evolution of a concept. Redox Biol 2015; 6:524-551.

62. Granger DN, McCord JM, Parks DA, Hollwarth ME. Xanthine oxidase inhibitors attenuate ischemia-induced vascular permeability changes in the cat intestine. Gastroenterology 1986b; 90:80-84.

63. Granger DN, Rutili G, McCord JM. Superoxide radicals in feline intestinal ischemia. Gastroenterology 1981; 81:22-29.

64. Griendling KK, Touyz RM, Zweier JL, Dikalov S, Chilian W, Chen YR, Harrison DG, Bhatnagar A. Measurement of Reactive Oxygen Species, Reactive Nitrogen Species, and Redox-Dependent Signaling in the Cardiovascular System: A Scientific Statement From the American Heart Association. Circ. Res. 2016; 119:e39-75.

65. Grootjans J, Thuijls G, Derikx JP, van Dam RM, Dejong CH, Buurman WA. Rapid lamina propria retraction and zipper-like constriction of the epithelium preserves the epithelial lining in human small intestine exposed to ischaemia-reperfusion. J. Pathol. 2011; 224:411-419.

66. Gruen DW, Haydon DA. The adsorption of nonpolar molecules into lipid bilayer membranes. Biophys. J. 1980; 30:129-136.

67. Guzman-de la Garza FJ, Camara-Lemarroy CR, Alarcon-Galvan G, Cordero-Perez P, MunozEspinosa LE, Fernandez-Garza NE. Different patterns of intestinal response to injury after arterial, venous or arteriovenous occlusion in rats. World J. Gastroenterol. 2009; 15:3901-3907.

68. Haglund U, Hulten L, Ahren C, Lundgren O. Mucosal lesions in the human small intestine in shock. Gut 1975; 16:979-984.

69. Hamanaka RB, Chandel NS. Mitochondrial reactive oxygen species regulate cellular signaling and dictate biological outcomes. Trends Biochem. Sci. 2010; 35:505-513.

70. Hansford RG, Hogue BA, Mildaziene V. Dependence of $\mathrm{H} 2 \mathrm{O} 2$ formation by rat heart mitochondria on substrate availability and donor age. J. Bioenerg. Biomembr. 1997; 29:89-95.

71. Hardeman MR, Goedhart PT, Schut NH. Laser-assisted optical rotational cell analyser (LORCA). II: Red blood cell deformability: elongation index versus cell transit time. Clin. Hemorheol. Microcirc. 1994; 14:619-630.

72. Harrison R. Structure and function of xanthine oxidoreductase: where are we now? Free Radic. Biol. Med. 2002; 33:774-797.

73. Hassoun PM, Yu FS, Shedd AL, Zulueta JJ, Thannickal VJ, Lanzillo JJ, Fanburg BL. Regulation of endothelial cell xanthine dehydrogenase xanthine oxidase gene expression by oxygen tension. Am. J. Physiol. 1994; 266:L163-171. 
74. He R, Wang L, Zhu J, Fei M, Bao S, Meng Y, Wang Y, Li J, Deng X. Methane-rich saline protects against concanavalin A-induced autoimmune hepatitis in mice through anti-inflammatory and anti-oxidative pathways. Biochem. Biophys. Res. Commun. 2016; 470:22-28.

75. Hearse DJ, Humphrey SM, Chain EB. Abrupt reoxygenation of the anoxic potassium-arrested perfused rat heart: A study of myocardial enzyme release. J. Mol. Cell. Cardiol. 1973; 5:395-407.

76. Helander HF, Fändriks L. Surface area of the digestive tract - revisited. Scand. J. Gastroenterol. 2014; 49:681-689.

77. Hernandez LA, Grisham MB, Twohig B, Arfors KE, Harlan JM, Granger DN. Role of Neutrophils in Ischemia-Reperfusion-Induced Microvascular Injury. Am. J. Physiol. 1987; 253:H699-H703.

78. Hirst DG, Robson T. Nitric oxide physiology and pathology. Methods Mol. Biol. 2011; 704:1-13.

79. Hogg N, Kalyanaraman B. Nitric oxide and lipid peroxidation. Biochim. Biophys. Acta 1999; 1411:378-384.

80. Huang Z, Shiva S, Kim-Shapiro DB, Patel RP, Ringwood LA, Irby CE, Huang KT, Ho C, Hogg $\mathrm{N}$, Schechter AN, Gladwin MT. Enzymatic function of hemoglobin as a nitrite reductase that produces NO under allosteric control. J. Clin. Invest. 2005; 115:2099-2107.

81. Hurkuck M, Althoff F, Jungkunst HF, Jugold A, Keppler F. Release of methane from aerobic soil: an indication of a novel chemical natural process? Chemosphere 2012; 86:684-689.

82. Ichikawa H, Takagi T, Uchiyama K, Higashihara H, Katada K, Isozaki Y, Naito Y, Yoshida N, Yoshikawa T. Rotenone, a mitochondrial electron transport inhibitor, ameliorates ischemiareperfusion-induced intestinal mucosal damage in rats. Redox Report 2004; 9:313-316.

83. Ignarro LJ, Byrns RE, Buga GM, Wood KS. Endothelium-derived relaxing factor from pulmonary artery and vein possesses pharmacologic and chemical properties identical to those of nitric oxide radical. Circ. Res. 1987; 61:866-879.

84. Jia L, Bonaventura C, Bonaventura J, Stamler JS. S-nitrosohaemoglobin: a dynamic activity of blood involved in vascular control. Nature 1996; 380:221-226.

85. Jung K-H, Chu K, Ko S-Y, Lee S-T, Sinn D-I, Park D-K, Kim J-M, Song E-C, Kim M, Roh J-K. Early Intravenous Infusion of Sodium Nitrite Protects Brain Against In Vivo IschemiaReperfusion Injury. Stroke 2006; 37:2744-2750.

86. Kagan VE, Tyurin VA, Jiang J, Tyurina YY, Ritov VB, Amoscato AA, Osipov AN, Belikova NA, Kapralov AA, Kini V, Vlasova, II, Zhao Q, Zou M, Di P, Svistunenko DA, Kurnikov IV, Borisenko GG. Cytochrome $\mathrm{c}$ acts as a cardiolipin oxygenase required for release of proapoptotic factors. Nat. Chem. Biol. 2005; 1:223-232.

87. Kayar E, Mat F, Meiselman HJ, Baskurt OK. Red blood cell rheological alterations in a rat model of ischemia-reperfusion injury. Biorheology 2001; 38:405-414.

88. Kayyali US, Donaldson C, Huang H, Abdelnour R, Hassoun PM. Phosphorylation of xanthine dehydrogenase/oxidase in hypoxia. J. Biol. Chem. 2001; 276:14359-14365.

89. Kelly CJ, Glover LE, Campbell EL, Kominsky DJ, Ehrentraut SF, Bowers BE, Bayless AJ, Saeedi BJ, Colgan SP. Fundamental role for HIF-1alpha in constitutive expression of human beta defensin-1. Mucosal Immunol. 2013; 6:1110-1118.

90. Keppler F, Schiller A, Ehehalt R, Greule M, Hartmann J, Polag D. Stable isotope and high precision concentration measurements confirm that all humans produce and exhale methane. $J$. Breath Res. 2016; 10:016003.

91. Khambata RS, Ghosh SM, Ahluwalia A. "Repurposing" of Xanthine Oxidoreductase as a Nitrite Reductase: A New Paradigm for Therapeutic Targeting in Hypertension. Antioxid. Redox Signal. 2015; 23:340-353.

92. Kiesewetter H, Radtke H, Schneider R, Mußler K, Scheffler A, Schmid-Schönbein H. (1982). Das Mini-Erythrozyten-Aggregometer: Ein neues Gerät zur schnellen Quantifizierung des Ausmaßes der Erythrozyten-aggregation Mini Erythrocyte Aggregometer: A New Apparatus for 
Rapid Quantification of the extent of Erythrocyte Aggregation. In: Biomed. Tech./Biomed. Eng., vol. 27, 209.

93. Kitzenberg D, Colgan SP, Glover LE. Creatine kinase in ischemic and inflammatory disorders. Clinical and Translational Medicine 2016; 5:31.

94. Kozlov AV, Albrecht M, Donnelly EM, Jafarmadar M, Szelenyi Z, Nohl H, Redl H, Bahrami S. Release and hemodynamic influence of nitro-glycerine-derived nitric oxide in endotoxemic rats. Vascul. Pharmacol. 2005; 43:411-414.

95. Kozlov AV, Sobhian B, Costantino G, Nohl H, Redl H, Bahrami S. Experimental evidence suggesting that nitric oxide diffuses from tissue into blood but not from blood into tissue. Biochim. Biophys. Acta 2001a; 1536:177-184.

96. Kozlov AV, Sobhian B, Duvigneau C, Gemeiner M, Nohl H, Redl H, Bahrami S. Organ specific formation of nitrosyl complexes under intestinal ischemia/reperfusion in rats involves NOSindependent mechanism(s). Shock 2001b; 15:366-371.

97. Kozlov AV, Staniek K, Nohl $\mathrm{H}$. Nitrite reductase activity is a novel function of mammalian mitochondria. FEBS Lett. 1999; 454:127-130.

98. Krab K, Kempe H, Wikstrom M. Explaining the enigmatic $\mathrm{K}(\mathrm{M})$ for oxygen in cytochrome c oxidase: a kinetic model. Biochim. Biophys. Acta 2011; 1807:348-358.

99. Kuchan MJ, Frangos JA. Shear stress regulates endothelin-1 release via protein kinase $C$ and cGMP in cultured endothelial cells. Am. J. Physiol. 1993; 264:H150-156.

100. Kuebler WM, Abels C, Schuerer L, Goetz AE. Measurement of neutrophil content in brain and lung tissue by a modified myeloperoxidase assay. Int. J. Microcirc. Clin. Exp. 1996; 16:89-97.

101. Kurtel H, Ghandour S. Endothelins and inflammation: the gastrointestinal system. Pathophysiology 1999; 6:77-89.

102. Laukoetter MG, Bruewer M, Nusrat A. Regulation of the intestinal epithelial barrier by the apical junctional complex. Curr Opin Gastroenterol 2006; 22:85-89.

103. Lee KN, Lee OY, Koh DH, Sohn W, Lee SP, Jun DW, Lee HL, Yoon BC, Choi HS, Hahm JS. Association between Symptoms of Irritable Bowel Syndrome and Methane and Hydrogen on Lactulose Breath Test. Journal of Korean medical science 2013; 28:901-907.

104. Levitt MD. Volume and composition of human intestinal gas determined by means of an intestinal washout technic. N. Engl. J. Med. 1971; 284:1394-1398.

105. Liu L, Sun Q, Wang R, Chen Z, Wu J, Xia F, Fan X-q. Methane attenuates retinal ischemia/reperfusion injury via anti-oxidative and anti-apoptotic pathways. Brain Res. 2016; 1646:327-333.

106. Liu W, Wang D, Liu K, Sun X. Nrf2 as a converging node for cellular signaling pathways of gasotransmitters. Med. Hypotheses 2012; 79:308-310.

107. Liu X, Miller MJS, Joshi MS, Thomas DD, Lancaster JR. Accelerated reaction of nitric oxide with $\mathrm{O} 2$ within the hydrophobic interior of biological membranes. Proc. Natl. Acad. Sci. U. S. A. 1998; 95:2175-2179.

108. Lorne E, Zmijewski JW, Zhao X, Liu G, Tsuruta Y, Park YJ, Dupont H, Abraham E. Role of extracellular superoxide in neutrophil activation: interactions between xanthine oxidase and TLR4 induce proinflammatory cytokine production. Am. J. Physiol. Cell Physiol. 2008; 294:C985-993.

109. Lowry OH, Rosebrough NJ, Farr AL, Randall RJ. Protein measurement with the Folin phenol reagent. J. Biol. Chem. 1951; 193:265-275.

110. Lundberg JO, Weitzberg E, Lundberg JM, Alving K. Intragastric nitric oxide production in humans: measurements in expelled air. Gut 1994; 35:1543-1546.

111. MacMicking J, Xie Q-w, Nathan C. Nitric oxide and macrophage function. Annu. Rev. Immunol. 1997; 15:323-350. 
112. Maeda A, Fadeel B. Mitochondria released by cells undergoing TNF-[alpha]-induced necroptosis act as danger signals. Cell Death Dis. 2014; 5:e1312.

113. Maia LB, Pereira V, Mira L, Moura JJG. Nitrite Reductase Activity of Rat and Human Xanthine Oxidase, Xanthine Dehydrogenase, and Aldehyde Oxidase: Evaluation of Their Contribution to NO Formation in Vivo. Biochemistry 2015; 54:685-710.

114. Mao Y-F, Zheng X-F, Cai J-M, You X-M, Deng X-M, Zhang JH, Jiang L, Sun X-J. Hydrogenrich saline reduces lung injury induced by intestinal ischemia/reperfusion in rats. Biochem. Biophys. Res. Commun. 2009; 381:602-605.

115. Martinez-Revelles S, Caracuel L, Marquez-Martin A, Dantas A, Oliver E, D'Ocon P, Vila E. Increased endothelin-1 vasoconstriction in mesenteric resistance arteries after superior mesenteric ischaemia-reperfusion. Br. J. Pharmacol. 2012; 165:937-950.

116. Masaki T. Historical review: Endothelin. Trends Pharmacol. Sci. 2004; 25:219-224.

117. Matthijsen RA, Derikx JP, Kuipers D, van Dam RM, Dejong CH, Buurman WA. Enterocyte shedding and epithelial lining repair following ischemia of the human small intestine attenuate inflammation. PLoS One 2009; 4:e7045.

118. McCord JM. Oxygen-derived free radicals in postischemic tissue injury. N. Engl. J. Med. 1985; 312:159-163.

119. Menger MD, Rucker M, Vollmar B. Capillary dysfunction in striated muscle ischemia/reperfusion: on the mechanisms of capillary "no-reflow". Shock 1997; 8:2-7.

120. Meyer M, Tebbe U, Piiper J. Solubility of inert gases in dog blood and skeletal muscle. Pflügers Archiv 1980; 384:131-134.

121. Miller KW, Hammond L, Porter EG. The solubility of hydrocarbon gases in lipid bilayers. Chem. Phys. Lipids 1977; 20:229-241.

122. Mitchell P. Chemiosmotic coupling in oxidative and photosynthetic phosphorylation. Biochim. Biophys. Acta 2011; 1807:1507-1538.

123. Mittal M, Siddiqui MR, Tran K, Reddy SP, Malik AB. Reactive oxygen species in inflammation and tissue injury. Antioxid. Redox Signal. 2014; 20:1126-1167.

124. Mohandas N, Chasis JA. Red blood cell deformability, membrane material properties and shape: regulation by transmembrane, skeletal and cytosolic proteins and lipids. Semin. Hematol. 1993; 30:171-192.

125. Moore EE, Moore FA, Franciose RJ, Kim FJ, Biffl WL, Banerjee A. The postischemic gut serves as a priming bed for circulating neutrophils that provoke multiple organ failure. J. Trauma 1994; 37:881-887.

126. Moorhouse PC, Grootveld M, Halliwell B, Quinlan JG, Gutteridge JM. Allopurinol and oxypurinol are hydroxyl radical scavengers. FEBS Lett. 1987; 213:23-28.

127. Murphy E, Steenbergen C. Mechanisms underlying acute protection from cardiac ischemiareperfusion injury. Physiol. Rev. 2008; 88:581-609.

128. Nanobashvili J, Neumayer C, Fuegl A, Sporn E, Prager M, Polterauer P, Malinski T, Huk I. Ischaemia/Reperfusion Injury of Skeletal Muscle: Mechanisms, Morphology, Treatment Strategies, and Clinical Applications. European Surgery 2002; 34:83-89.

129. Nemeth N, Lesznyak T, Szokoly M, Furka I, Miko I. Allopurinol prevents erythrocyte deformability impairing but not the hematological alterations after limb ischemia-reperfusion in rats. J. Invest. Surg. 2006; 19:47-56.

130. Niture SK, Khatri R, Jaiswal AK. Regulation of Nrf2-an update. Free Radic. Biol. Med. 2014; 66:36-44.

131. Nose K, Nunome Y, Kondo T, Araki S, Tsuda T. Identification of gas emanated from human skin: methane, ethylene, and ethane. Anal. Sci. 2005; 21:625-628. 
132. Oktar BK, Gulpinar MA, Bozkurt A, Ghandour S, Cetinel S, Moini H, Yegen BC, Bilsel S, Granger DN, Kurtel H. Endothelin receptor blockers reduce I/R-induced intestinal mucosal injury: role of blood flow. Am. J. Physiol. Gastrointest. Liver Physiol. 2002; 282:G647-655.

133. Olofsson P, Nylander G, Olsson P. Endotoxin-transport routes and kinetics in intestinal ischemia. Acta Chir. Scand. 1985; 151:635-639.

134. Ozaki KS, Kimura S, Murase N. Use of carbon monoxide in minimizing ischemia/reperfusion injury in transplantation. Transplant Rev (Orlando) 2012; 26:125-139.

135. Parks DA, Granger DN. Contributions of ischemia and reperfusion to mucosal lesion formation. Am. J. Physiol. Gastrointest. Liver Physiol. 1986a; 250:G749-G753.

136. Parks DA, Granger DN. Xanthine oxidase: biochemistry, distribution and physiology. Acta Physiol. Scand. Suppl. 1986b; 548:87-99.

137. Petersen LC, Nicholls P, Degn H. The effect of energization on the apparent Michaelis-Menten constant for oxyge in nmitochondrial respiration. Biochem. J. 1974; 142:247-252.

138. Piccinini AM, Midwood KS. DAMPening Inflammation by Modulating TLR Signalling. Mediators Inflamm. 2010; 2010:21.

139. Pilz RB, Suhasini M, Idriss S, Meinkoth JL, Boss GR. Nitric oxide and cGMP analogs activate transcription from AP-1-responsive promoters in mammalian cells. The FASEB Journal 1995; 9:552-558.

140. Pimentel M, Lin HC, Enayati P, van den Burg B, Lee HR, Chen JH, Park S, Kong Y, Conklin J. Methane, a gas produced by enteric bacteria, slows intestinal transit and augments small intestinal contractile activity. Am. J. Physiol. Gastrointest. Liver Physiol. 2006; 290:G1089-1095.

141. Pozuelo M, Panda S, Santiago A, Mendez S, Accarino A, Santos J, Guarner F, Azpiroz F, Manichanh C. Reduction of butyrate- and methane-producing microorganisms in patients with Irritable Bowel Syndrome. Sci. Rep. 2015; 5:12693.

142. Quinlan CL, Orr AL, Perevoshchikova IV, Treberg JR, Ackrell BA, Brand MD. Mitochondrial Complex II Can Generate Reactive Oxygen Species at High Rates in Both the Forward and Reverse Reactions. J. Biol. Chem. 2012; 287:27255-27264.

143. Rabai M, Toth A, Kenyeres P, Mark L, Marton Z, Juricskay I, Toth K, Czopf L. In vitro hemorheological effects of red wine and alcohol-free red wine extract. Clin. Hemorheol. Microcirc. 2010; 44:227-236.

144. Reinhart WH. Molecular biology and self-regulatory mechanisms of blood viscosity: a review. Biorheology 2001; 38:203-212.

145. Reinhart WH, Chien S. Roles of cell geometry and cellular viscosity in red cell passage through narrow pores. American Journal of Physiology - Cell Physiology 1985; 248:C473-C479.

146. Ryter SW, Alam J, Choi AM. Heme oxygenase-1/carbon monoxide: from basic science to therapeutic applications. Physiol. Rev. 2006; 86:583-650.

147. Saeedi BJ, Kao DJ, Kitzenberg DA, Dobrinskikh E, Schwisow KD, Masterson JC, Kendrick AA, Kelly CJ, Bayless AJ, Kominsky DJ, Campbell EL, Kuhn KA, Furuta GT, Colgan SP, Glover LE. HIF-dependent regulation of claudin-1 is central to intestinal epithelial tight junction integrity. Mol. Biol. Cell 2015; 26:2252-2262.

148. Salzman AL, Menconi MJ, Unno N, Ezzell RM, Casey DM, Gonzalez PK, Fink MP. Nitric oxide dilates tight junctions and depletes ATP in cultured Caco-2BBe intestinal epithelial monolayers. Am. J. Physiol. 1995; 268:G361-373.

149. Samouilov A, Woldman YY, Zweier JL, Khramtsov VV. Magnetic resonance study of the transmembrane nitrite diffusion. Nitric Oxide 2007; 16:362-370.

150. Schardinger F. Ueber das Verhalten der Kuhmilch gegen Methylenblau und seine Verwendung zur Unterscheidung von ungekochter und gekochter Milch. Zeitschrift für Untersuchung der Nahrungs- und Genußmittel, sowie der Gebrauchsgegenstände 1902; 5:1113-1121. 
151. Schneider MP, Boesen EI, Pollock DM. Contrasting actions of endothelin ET(A) and ET(B) receptors in cardiovascular disease. Annu. Rev. Pharmacol. Toxicol. 2007; 47:731-759.

152. Segal AW, Allison AC. Oxygen consumption by stimulated human neutrophils. Ciba Found. Symp. 1978:205-223.

153. Sergent O, Tomasi A, Ceccarelli D, Masini A, Nohl H, Cillard P, Cillard J, Vladimirov YA, Kozlov AV. Combination of iron overload plus ethanol and ischemia alone give rise to the same endogenous free iron pool. Biometals 2005; 18:567-575.

154. Shen M, Fan D, Zang Y, Chen Y, Zhu K, Cai Z, Liu Y, Sun X, Liu J, Gong J. Neuroprotective effects of methane-rich saline on experimental acute carbon monoxide toxicity. J. Neurol. Sci. 2016; 369:361-367.

155. Shiva S, Gladwin MT. Nitrite mediates cytoprotection after ischemia/reperfusion by modulating mitochondrial function. Basic Res. Cardiol. 2009; 104:113.

156. Shiva S, Oh J-Y, Landar AL, Ulasova E, Venkatraman A, Bailey SM, Darley-Usmar VM. Nitroxia: The pathological consequence of dysfunction in the nitric oxide-cytochrome c oxidase signaling pathway. Free Radic. Biol. Med. 2005; 38:297-306.

157. Skulachev VP. Role of uncoupled and non-coupled oxidations in maintenance of safely low levels of oxygen and its one-electron reductants. Q. Rev. Biophys. 1996; 29:169-202.

158. Song K, Zhang M, Hu J, Liu Y, Liu Y, Wang Y, Ma X. Methane-rich saline attenuates ischemia/reperfusion injury of abdominal skin flaps in rats via regulating apoptosis level. $B M C$ Surg. 2015; 15:92.

159. Sparacino-Watkins CE, Tejero J, Sun B, Gauthier MC, Thomas J, Ragireddy V, Merchant BA, Wang J, Azarov I, Basu P, Gladwin MT. Nitrite reductase and nitric-oxide synthase activity of the mitochondrial molybdopterin enzymes mARC1 and mARC2. J. Biol. Chem. 2014; 289:1034510358.

160. Stamler JS, Singel DJ, Loscalzo J. Biochemistry of nitric oxide and its redox-activated forms. Science 1992; 258:1898-1902.

161. Strifler G, Tuboly E, Szél E, Kaszonyi E, Cao C, Kaszaki J, Mészáros A, Boros M, Hartmann P. Inhaled Methane Limits the Mitochondrial Electron Transport Chain Dysfunction during Experimental Liver Ischemia-Reperfusion Injury. PLoS One 2016; 11:e0146363.

162. Subczynski WK, Hyde JS. Concentration of oxygen in lipid bilayers using a spin-label method. Biophys. J. 1983; 41:283-286.

163. Szabo A, Menger MD, Boros M. Microvascular and epithelial permeability measurements in laboratory animals. Microsurgery 2006; 26:50-53.

164. Szabo A, Vollmar B, Boros M, Menger MD. In vivo fluorescence microscopic imaging for dynamic quantitative assessment of intestinal mucosa permeability in mice. J. Surg. Res. 2008; 145:179-185.

165. Szabo C, Ischiropoulos H, Radi R. Peroxynitrite: biochemistry, pathophysiology and development of therapeutics. Nat. Rev. Drug Discov. 2007; 6:662-680.

166. Szczesny B, Modis K, Yanagi K, Coletta C, Le Trionnaire S, Perry A, Wood ME, Whiteman M, Szabo C. AP39, a novel mitochondria-targeted hydrogen sulfide donor, stimulates cellular bioenergetics, exerts cytoprotective effects and protects against the loss of mitochondrial DNA integrity in oxidatively stressed endothelial cells in vitro. Nitric Oxide 2014; 41:120-130.

167. Szentpali K, Kaszaki J, Tiszlavicz L, Lazar G, Balogh A, Boros M. Bile-induced adenosine triphosphate depletion and mucosal damage during reflux esophagitis. Scand. J. Gastroenterol. 2001; 36:459-466.

168. Tahara EB, Navarete FD, Kowaltowski AJ. Tissue-, substrate-, and site-specific characteristics of mitochondrial reactive oxygen species generation. Free Radic. Biol. Med. 2009; 46:1283-1297.

169. Thomas DD. Breathing new life into nitric oxide signaling: A brief overview of the interplay between oxygen and nitric oxide. Redox Biology 2015; 5:225-233. 
170. Thomas DD, Liu X, Kantrow SP, Lancaster JR. The biological lifetime of nitric oxide: Implications for the perivascular dynamics of $\mathrm{NO}$ and O2. Proc. Natl. Acad. Sci. U. S. A. 2001; 98:355-360.

171. Toledo JC, Jr., Augusto O. Connecting the chemical and biological properties of nitric oxide. Chem. Res. Toxicol. 2012; 25:975-989.

172. Tripatara P, Patel NSA, Webb A, Rathod K, Lecomte FMJ, Mazzon E, Cuzzocrea S, Yaqoob MM, Ahluwalia A, Thiemermann C. Nitrite-Derived Nitric Oxide Protects the Rat Kidney against Ischemia/Reperfusion Injury In Vivo: Role for Xanthine Oxidoreductase. J. Am. Soc. Nephrol. 2007; 18:570-580.

173. Trujillo M, Alvarez MN, Peluffo G, Freeman BA, Radi R. Xanthine oxidase-mediated decomposition of S-nitrosothiols. J. Biol. Chem. 1998; 273:7828-7834.

174. Tsuda K, Kimura K, Nishio I, Masuyama Y. Nitric oxide improves membrane fluidity of erythrocytes in essential hypertension: An electron paramagnetic resonance investigation. Biochem. Biophys. Res. Commun. 2000; 275:946-954.

175. Tsukamoto T, Nigam SK. Tight junction proteins form large complexes and associate with the cytoskeleton in an ATP depletion model for reversible junction assembly. J. Biol. Chem. 1997; 272:16133-16139.

176. Tuboly E, Szabo A, Eros G, Mohacsi A, Szabo G, Tengolics R, Rakhely G, Boros M. Determination of endogenous methane formation by photoacoustic spectroscopy. J. Breath Res. 2013a; 7:046004.

177. Tuboly E, Szabo A, Garab D, Bartha G, Janovszky A, Eros G, Szabo A, Mohacsi A, Szabo G, Kaszaki J, Ghyczy M, Boros M. Methane biogenesis during sodium azide-induced chemical hypoxia in rats. Am. J. Physiol. Cell Physiol. 2013b; 304:C207-214.

178. Vajda K, Szabo A, Kucsa K, Suki B, Boros M. Microcirculatory heterogeneity in the rat small intestine during compromised flow conditions. Microcirculation 2004; 11:307-315.

179. van Faassen EE, Bahrami S, Feelisch M, Hogg N, Kelm M, Kim-Shapiro DB, Kozlov AV, Li H, Lundberg JO, Mason R, Nohl H, Rassaf T, Samouilov A, Slama-Schwok A, Shiva S, Vanin AF, Weitzberg E, Zweier J, Gladwin MT. Nitrite as regulator of hypoxic signaling in mammalian physiology. Med. Res. Rev. 2009; 29:683-741.

180. Vanderkooi JM, Erecinska M, Silver IA. Oxygen in mammalian tissue: methods of measurement and affinities of various reactions. Am. J. Physiol. 1991; 260:C1131-1150.

181. Vaure C, Liu Y. A Comparative Review of Toll-Like Receptor 4 Expression and Functionality in Different Animal Species. Front. Immunol. 2014; 5.

182. Vlasova, II, Tyurin VA, Kapralov AA, Kurnikov IV, Osipov AN, Potapovich MV, Stoyanovsky DA, Kagan VE. Nitric oxide inhibits peroxidase activity of cytochrome c.cardiolipin complex and blocks cardiolipin oxidation. J. Biol. Chem. 2006; 281:14554-14562.

183. Vollmar B, Menger MD. Intestinal ischemia/reperfusion: microcirculatory pathology and functional consequences. Langenbecks Arch. Surg. 2011; 396:13-29.

184. Wang J, Krizowski S, Fischer-Schrader K, Niks D, Tejero J, Sparacino-Watkins C, Wang L, Ragireddy V, Frizzell S, Kelley EE, Zhang Y, Basu P, Hille R, Schwarz G, Gladwin MT. Sulfite Oxidase Catalyzes Single-Electron Transfer at Molybdenum Domain to Reduce Nitrite to Nitric Oxide. Antioxid. Redox Signal. 2015; 23:283-294.

185. Wang R. Physiological implications of hydrogen sulfide: a whiff exploration that blossomed. Physiol. Rev. 2012; 92:791-896.

186. Wang R. Gasotransmitters: growing pains and joys. Trends Biochem. Sci. 2014; 39:227-232.

187. Watanabe H, Kobayashi A, Yamamoto T, Suzuki S, Hayashi H, Yamazaki N. Alterations of human erythrocyte membrane fluidity by oxygen-derived free radicals and calcium. Free Radic. Biol. Med. 1990; 8:507-514. 
188. Wattanasirichaigoon S, Menconi MJ, Delude RL, Fink MP. Effect of mesenteric ischemia and reperfusion or hemorrhagic shock on intestinal mucosal permeability and ATP content in rats. Shock 1999; 12:127-133.

189. Webb A, Bond R, McLean P, Uppal R, Benjamin N, Ahluwalia A. Reduction of nitrite to nitric oxide during ischemia protects against myocardial ischemia-reperfusion damage. Proc. Natl. Acad. Sci. U. S. A. 2004; 101:13683-13688.

190. Weidinger A, Kozlov AV. Biological Activities of Reactive Oxygen and Nitrogen Species: Oxidative Stress versus Signal Transduction. Biomolecules 2015; 5:472-484.

191. Wikstrom M. Cytochrome c oxidase: 25 years of the elusive proton pump. Biochim. Biophys. Acta 2004; 1655:241-247.

192. Wishkerman A, Greiner S, Ghyczy M, Boros M, Rausch T, Lenhart K, Keppler F. Enhanced formation of methane in plant cell cultures by inhibition of cytochrome c oxidase. Plant Cell Environ. 2011; 34:457-464.

193. Wongnate T, Ragsdale SW. The Reaction Mechanism of Methyl-Coenzyme M Reductase: How an Enzyme Enforces Strict Binding Order. J. Biol. Chem. 2015; 290:9322-9334.

194. Wu J, Wang R, Ye Z, Sun X, Chen Z, Xia F, Sun Q, Liu L. Protective effects of methane-rich saline on diabetic retinopathy via anti-inflammation in a streptozotocin-induced diabetic rat model. Biochem. Biophys. Res. Commun. 2015; 466:155-161.

195. Wu L, Wang R. Carbon monoxide: endogenous production, physiological functions, and pharmacological applications. Pharmacol. Rev. 2005; 57:585-630.

196. Xin L, Sun X, Lou S. Effects of Methane-Rich Saline on the Capability of One-Time Exhaustive Exercise in Male SD Rats. PLoS One 2016; 11:e0150925.

197. Yang Z, Sharma AK, Marshall M, Kron IL, Laubach VE. NADPH Oxidase in Bone MarrowDerived Cells Mediates Pulmonary Ischemia-Reperfusion Injury. Am. J. Respir. Cell Mol. Biol. 2009; 40:375-381.

198. Ye Z, Chen O, Zhang R, Nakao A, Fan D, Zhang T, Gu Z, Tao H, Sun X. Methane Attenuates Hepatic Ischemia/Reperfusion Injury in Rats Through Antiapoptotic, Anti-Inflammatory, and Antioxidative Actions. Shock 2015; 44:181-187.

199. Zhang X, Li N, Shao H, Meng Y, Wang L, Wu Q, Yao Y, Li J, Bian J, Zhang Y, Deng X. Methane limit LPS-induced NF- $\mathrm{KB} / \mathrm{MAPKs}$ signal in macrophages and suppress immune response in mice by enhancing PI3K/AKT/GSK-3ß-mediated IL-10 expression. Sci. Rep. 2016; 6:29359.

200. Zhang Z, Naughton D, Winyard PG, Benjamin N, Blake DR, Symons MC. Generation of nitric oxide by a nitrite reductase activity of xanthine oxidase: a potential pathway for nitric oxide formation in the absence of nitric oxide synthase activity. Biochem. Biophys. Res. Commun. 1998; 249:767-772.

201. Zheng X, Zheng X, Mao Y, Cai J, Li Y, Liu W, Sun P, Zhang JH, Sun X, Yuan H. Hydrogen-rich saline protects against intestinal ischemia/reperfusion injury in rats. Free Radic. Res. 2009; 43:478-484.

202. Zorov DB, Filburn CR, Klotz L-O, Zweier JL, Sollott SJ. Reactive Oxygen Species (ROSInduced) ROS Release: A New Phenomenon Accompanying Induction of the Mitochondrial Permeability Transition in Cardiac Myocytes. J. Exp. Med. 2000; 192:1001-1014.

203. Zweier JL, Flaherty JT, Weisfeldt ML. Direct measurement of free radical generation following reperfusion of ischemic myocardium. Proc. Natl. Acad. Sci. U. S. A. 1987; 84:1404-1407. 
IX. Annex 
